\title{
Economic effects of occupational regulation
}

\author{
Dissertation \\ zur Erlangung des Doktorgrades \\ der Wirtschaftswissenschaftlichen Fakultät \\ der Georg-August-Universität Göttingen
}

vorgelegt von

Kaja Bonesmo Fredriksen

Geboren in Trondheim

Göttingen, 2018

Erstgutachter: Prof. Dr. Kilian Bizer

Zweitgutachter: Prof. Dr. Markus Spiwoks

Weiteres Mitglied der Prüfungskommission: Prof. Dr. Thomas Kneib 


\section{Table of content}

Chapter I: Introduction and summary

Chapter II: Masterful Meisters?

Voluntary Certification and Quality in the German Crafts Sector

Chapter III: Does occupational licensing really impact incomes?

- The German crafts case

Chapter IV: Are estimates of the "natural experiment"

in the German crafts sector causal?

Chapter V: Ökonomische Effekte der Deregulierung der Handwerksordnung im Jahr 2004 - ein Literaturüberblick 
Chapter I: Introduction and summary 
"In the department of economy, an act, a habit, an institution, a law, gives birth not only to an effect, but to a series of effects. Of these effects, the first only is immediate; it manifests itself simultaneously with its cause - it is seen. The others unfold in succession - they are not seen: it is well for us, if they are foreseen" (Bastiat, 1850)

This thesis is motivated by the wish to balance the public debate on regulation. Even in market-based economies, individuals are surrounded by public regulations. This is what economists refer to as command-and-control instruments. In its most basic definition, "a regulation is a law that seeks to change behavior in order to produce desired outcomes, and it does this by requiring or forbidding certain actions (McLauglin, 2013, p. 2).

By choosing the word "balance" I here refer to the fact that command and control regulations - like allocating additional public funds - are often called for as they are very effective in order to achieve an end deemed to be socially desirable. McLauglin (2013) claims that there is an intrinsic drive for regulation to accumulate over time as the political system often reacts to perceived crises, new technologies and other undesirous events by creating new regulations.

However, there are costs to regulations, which are perhaps less visible and hence less present in the minds of policymakers and voters. An obvious source of costs is related to compliance. Regulations also create opportunity costs, a concept which French economist Bastiat (quoted above) was the first to introduce. He used the famous example of a broken window to illustrate the problem. In this parable, he juxtaposes the value created as the glazier is hired to fix a shop-keeper's broken window (effect which he refers to as "seen") with the value lost as the shop-keeper now cannot spend this money elsewhere (effect which he refers to as "unseen"). In a modern and succinct language, opportunity cost is productive activity foregone because scarce resources are devoted to regulatory compliance (McLaughlin, 2013). Also, it should be noted that regulation intrinsically restricts choices of those regulated. While this may lead to beneficial outcomes in the future both for the regulated and third parties, this fact should not be forgotten as most will agree that free choice is an important value.

A constructive public debate on regulations relies both on the acknowledgment of the benefits as well as the costs of existing regulations and regulatory options. Furthermore, as the number of different regulations grows and the economy gains in complexity, simply acknowledging that there are two sides to the regulatory coin will not be enough. Careful scientific evaluations and re-evaluations are necessary to get a complete picture of all actions set in motion by a policy making decision. Bastiat wrote that secondary effects of regulations can 
only become visible through experience or foresight. Using his words; when foresight is difficult, learning from experience becomes more important.

This book aims to teach public and policy-makers about the seen und unseen effects as well as regulatory options of a particular form of regulation - occupational licensing - by using the German crafts experience. National occupational licensing schemes have been steadily on the rise since the Second World War, in both Europe and the US (see Kleiner, 2006; and Kleiner and Kueger, 2010). For reference, about 30\% of the American workforce is employed in professions subject to such regulations. The German crafts sector has been subject to a licensing requirement for self-employment since the 1950's in its current form, however for several crafts trades this requirement was relieved or abolished in 2004 in order to cater to European goals of integrated, free markets.

To achieve this goal, this first introductory chapter of the book provides background information: It details the different theoretical approaches to occupational licensing, explains the occupational licensing scheme in the German crafts sector, introduces the reader to methodological challenges when trying to learn from the German experience and details the content, contributions to the literature and insights in the chapters to follow.

\section{The controversy surrounding occupational licensing}

Occupational licensing can be analyzed within two different theoretical frameworks that rest on opposite assumptions with regards to the existence of market failure and the market's ability to autocorrect them. This leads to different predictions of the effects of occupational licensing and finally also contrasting balance sheets on the social welfare effects of occupational licensing schemes.

A first approach sets on competition to maximize welfare and is fundamentally critical to state interventions. A central thesis in Stigler (1971) is that regulation as a rule is designed, put in place and operated primarily for the regulated industry's benefit. Also, Tullock (2004, p. 213) points out the "even in those cases where the government regulation was fairly clearly motivated by a desire to help some particular group, it is usually turns out that at least some features are not to the advantages of the benefitted group".

The underlying assumption for this view on occupational licensing is that there are no market failures such as information asymmetries, which the unregulated market itself cannot resolve. 
Indeed, even though producers may have an immediate upper hand in terms of information, the market will by itself reinstate the balance of powers. Various mechanisms that do not involve the government can reduce consumers' search costs in order to obtain their desired quality of products and services such as such as advertising, labeling, screening, reputation effects and voluntary certification (see e.g. Ippolito and Mathios, 1990; Dranove and Jin, 2010; and Cabral, 2012).

In regulated markets on the other hand, the compulsory qualification is a market entry barrier, which for the professionals themselves constitutes a fixed cost (see Branstetter et al., 2014). The higher this cost, the fewer professionals will pay to enter the market and hence the smaller total supply will be. Because of less competition, prices will rise above marginal costs. As a result, producers receive an economic rent and the total quantity produced in the market will be suboptimal, see Kleiner (2006). Since competition works as a sanctioning mechanism for poor-performing producers, another negative outcome of this process may be lower average quality offered in the regulated market. Hence, according to this thesis, occupational licensing schemes lead to welfare loss.

The second approach is rooted in the economics of information. The crucial assumption here is the opposite of the one taken by the proponents of market solutions: There are strong information asymmetries between consumers and producers that cannot be surmounted by the agents themselves. In the case of the crafts, there may be particular reason to suspect important information deficits. Leland (1979) showed that in particular service markets are prone to imperfect information. The specific nature of particular tasks makes the search for information about quality difficult for consumers. Also, services - as opposed to goods - are purchased before they are produced, which also complicates the task for consumers. Lastly, consumers have less experience with low frequency purchases, such as house refurbishments, hence information handicaps on the demand-side for such transactions seems plausible.

Economists have shown that market outcomes are sensitive to consumer information acquisition possibilities (see e.g. Salop and Stiglitz, 1977, 1982; Varian, 1980 and Wilde, 1980). Akerlof (1970) points out that when consumers are unable to evaluate quality ex-ante, i.e. in presence of asymmetric information, a "market-for-lemons" problem emerges, whereby the highest quality producers continuously leave the market since the consumers are only willing to pay the average price quoted, which does not cover their costs. Leland (1979) 
generalizes this finding by showing that all open markets with asymmetric information will underprovide quality relative to what is socially optimal.

By ensuring certain quality standards, an occupational licensing scheme prevents these problems and, hence, a complete opposite conclusion is reached in this second approach: Occupational licensing leads to welfare gains.

\section{The German crafts case}

The German craft sector provides researches with a golden opportunity to contribute to the empirical literature on the economic effects of occupational licensing since the traditional licensing scheme in this sector was recently reformed in a way that resembles a natural experiment. Hence, one can improve upon the existing literature, which relies solely on crosssection regression, by using difference-in-difference estimation.

Moreover, a better understanding of the developments in the crafts sector is important for the German policymaker since it constitutes an important part of the total economy. The German crafts sector comprises about 5 million professionals in 93 trades, which make up about 12\% of the working population (Federal Statistical Office, 2016). Also, the use of occupational licensing in the crafts sector is still part of the German policy debate.

The Trade and Crafts Code (Handwerksordnung) ${ }^{1}$ in its current institutional framework regulates this sector. From 1953 to 2004, it stipulated that only craftsmen with a Meister title could found a company. The Meister is the highest degree of vocational training. In order to acquire it a professional must first undergo basic training that typically lasts 3 years as well as additional training and associated exams that yields occupation specific knowledge and knowledge of business management and pedagogy. In line with European efforts to create a common market area with free labor mobility, the crafts regulation was liberalized in 2004 . Since then, market entry in certain trades has been open, although craftsmen in these trades can still choose to acquire the Meister title. In the remaining trades however, the licensing requirement remains fully or partially intact.

A number of empirical studies on the effects of the reform have been published in recent years. In summary, this literature provides the policymaker with the following insights:

\footnotetext{
${ }^{1}$ It should be noted that the German crafts legislation is not formally a state regulation as it was the instated by the crafts chambers with the state's blessing. In practice, it is however equivalent to a law initiated by the state.
} 
Removing occupational licensing leads to market entry, especially of low-qualified craftsmen (see Rostam-Afschar 2014; Runst et al., forthcoming; and Koch and Nielen). Market exit has also been shown to increase (see Runst et al. forthcoming). Income effects are significant though nevertheless quantitatively small - and hint at the elimination of a monopoly rent as a result of the regulation (Lergetporer et al., 2016; Damelang, 2017). Regarding education, the number of Meister certifications - previous market entry barrier in the deregulation professions - has decreased (Koch and Nielen, 2017). Also, in-company vocational training has gone down as a result of removing occupational licensing (Runst and Thomae, 2018).

Most of these studies solely rely on difference-in-differences estimation to obtain estimated reform effects. However, in contrast to laboratory experiments, natural experiments such as the German crafts reform rarely fulfill the random treatment condition. This means that the difference-in-differences estimator may not actually be able to identify casual effects.

\section{The pitfalls of econometric analyses}

Difference-in-differences estimation is a very popular methodology among economist researchers in order to gauge the effects of policy interventions. With good reason as it can help circumvent the problem of unobserved heterogeneity. However, in order to identify causal effects, the standard difference-in-differences estimator does require that, in absence of the treatment, the average outcomes for the treated and control groups would have followed parallel trends over time. This so-called parallel trends assumption is therefore the crucial identifying assumption for difference-in-differences estimation to be appropriate.

It is not possible to test whether the parallel trends assumption holds. O'Neill et al. (2016) therefore recommends "that the base case analysis should present results from the method(s) that uses the 'most plausible' identification assumption, but then the sensitivity analysis should present findings from method(s) that make alternative, but still 'somewhat plausible' identification assumption. None of the existing empirical studies on the effects of the German 2004 deregulation do this.

This calls for robustness-checks of the established findings using data driven procedures to construct the best possible counterfactual. In the policy evaluation literature, the synthetic control method has often been applied for this purpose (see e.g. Abadie et al., 2010; Kreif et al., 2016; O’Neill et al., 2016; and Peri and Yasenov, 2018). 
The general principle behind the synthetic control method is to weight the outcomes of the comparison units in order to construct a better counterfactual for the treated unit in absence of the treatment, with the weights being chosen such that the synthetic control best reproduces the outcome variable of the treated unit in the pre-treatment period.

Synthetic control estimations have several advantages. This method can still identify causal effects when the effects of unobserved confounders vary over time since the comparison group is reweighted so that it has similar characteristics as the treatment group. Also, it is a very transparent methodology since it is apparent whether the treated unit is sufficiently matched by the synthetic control and, on this basis, the analyst can decide whether or not to go forth with the analysis.

The synthetic control method is however not full-proof. In cases where the parallel assumption does hold, the difference-in-differences estimator does provide the best results (O’Neill et al., 2016) and alternative methods will yield biased results in this case (Angrist and Pischke, 2009; O’Neill et al., 2016). The safest bet therefore appears to be to present findings using different methodologies. It is only when these findings all go in the same direction that one can claim to have truly learnt from experience.

The chapters of my thesis will shed new light on the German crafts case. The presence of search costs in the now deregulated sector will be examined in order to assess whether a market-based approach to reduce information asymmetries can be successful and weaknesses in the existing empirical literature on the reform will be addressed using alternative methodologies.

\section{The chapters}

The second chapter of this book entitled "'Masterful Meisters? Voluntary Certification and Quality in the German Crafts Sector", examines consumers' search for information about quality in the segments of the German crafts sector that were deregulated in 2004. Chapter two contributes to the literature by being one of very first studies looking into the effects of voluntary certification and the only one examining this regulatory option in the case of Germany and in the case of the crafts.

The study empirically analyses whether the optional Meister certificate offers useful information about quality to consumers of deregulated crafts services. The main challenge 
herein lies in the measure of quality. A novel approach is taken by exploiting data from an online market platform for crafts services (MyHammer). After the job has been completed, consumers can leave an online rating about the crafts company that they employed on MyHammer, which is used as a measure of service quality. A second measure of quality is considered to be the time spent on the platform, since in the presence of market selection, high-quality crafts companies are more likely to continue using the MyHammer platform.

The data is analyzed using a cross-sectional linear regression, an ordered logit model, a truncated regression model and survival analysis. Across all empirical specifications, it is found that the Meister certification is perceived as a token of quality. We interpret this as a sign that the voluntary certification scheme in deregulated crafts trades reduces information search costs for consumers.

The third chapter of this book entitled "Does occupational licensing really impact incomes? The German crafts case" examines the income effects of the German reform in 2004. Most existing studies on the income effects of occupational licensing rely on cross-section estimates and are therefore likely to be biased due to unobserved heterogeneity. Furthermore, the studies on the German crafts sector using difference-in-differences estimation do not rigorously define the population of interest. Chapter three contributes to the literature on the link between licensing and incomes by improving upon the methodology used and the interpretation of the findings in these studies. Most notably, a more rigorous approach to identifying the crafts by combining occupation codes with data from the German Federal Institute for Vocational Education and Training on the share of crafts apprentices within each occupational code is used.

Surprisingly, no robust income effects as a result of the German 2004 deregulation are detected. It is suggested that demand-effects and market saturation have so far been inadequately discussed in the literature. While the economic reasoning in previous studies focuses on the mechanism whereby market entry barriers lead to higher prices and hence increase producers' incomes, other mechanisms that counterweigh this may be at work. It is possible that there may have been no - or very low - economic rents in licensed occupations to begin with. Several contributions in the literature have challenged the Cournot theorem, according to which a competitive equilibrium only occurs as the number of firms proceeds to infinity (see e.g. Fama and Laffer, 1972; Stiglitz, 1987 p. 1042; and Bresnahan and Riess, 1991). Moreover, the demand-side should also be considered. Quality may be lower in non- 
competitive markets, which over time could have reduced consumers' willingness to pay for the service.

The forth chapter of this book entitled "Are estimates of the "natural experiment" in the German crafts sector causal?" investigates whether results in the literature on the 2004-reform using difference-in-differences estimation hold up when methods to construct an improved counterfactual are used. More specifically, it re-examines the effects of the 2004 deregulation on market entry and exits, the share of migrants and incomes using the synthetic control method. It contributes to the literature by being the only one to apply synthetic control estimation in this particular policy case.

It is found that using synthetic control estimation does not significantly alter conclusions drawn based on difference-in-differences estimations, although some additional information was revealed.

Finally, the fifth and final chapter of book is entitled "Ökonomische Effekte der Deregulierung der Handwerksordnung im Jahr 2004 (author's note: Economic Effects of the Deregulation of the Crafts Legislation in the Year 2004)". It is an encompassing summary of policy insights on the economic effects of removing occupational licensing based on the entire research literature on the German deregulation of the crafts sector in 2004. This literature concludes with the fact that market competition has increased as a result of the reform. Whether this implies increased consumer welfare will depend on the long-term developments in the quality of services and, most importantly, whether available crafts services in the future are in line with consumer preferences.

\section{Conclusion}

As mentioned in the beginning of this introductory chapter; the ambition of this book is to inform the public debate about the seen and unseen effects of occupational licensing. The reader may rightfully ask: "Is there a need for such enlightenment?"

On the $24^{\text {th }}$ of July, the Frankfurter Allgemeine Zeitung - one of Germany's largest newspapers - wrote an article entitled "the return of the Meister-obligation". Here, Germans could read that their elected representatives are now starting to doubt whether the 2004deregulation was appropriate. They fear that quality of crafts services as well as human capital accumulation in coming crafts generations is going down. On the other hand, a scientist 
interviewed still applauds the increased competition as a result of removing occupational licensing. No published study is cited and no conclusion is given. Hence, there does appear to be a need for scientific evidence for the many and diverse economic consequences of removing occupational licensing in the German crafts sector, which is what the chapters that now follow will provide. Some of these effects are more visible in the German policy debate than others.

A meticulous reader will here point out: "So you inform the public of all these implications of occupational licensing, but will you give the answer as to whether the Meister-obligation should be reinstated in the deregulated occupations or perhaps overall be made history". This book is a so-called positive analysis. Like in so many other cases in the social sciences we are faced with policy trade-offs. Whether a licensing requirement is appropriate will depend on how we value different policy goal against each other. This is a normative question which no scientific paper can conclude on.

Even with this response the most inquisitive audience may not be satisfied. "But having read and written on the topic during 3 years, what is your personal opinion on occupational licensing in the German crafts?" I believe the crafts sector is so diverse that a single regulatory scheme for all trades may not be desirable. In the case of backers, putting competition and innovation at the forefront appears logical, whereas for craftsmen installing complex heating structure in buildings that will last for decades, prioritizing quality assurance seems like a good idea.

As for a general rule of thumb, I have throughout the years of writing this book, truly become aware that regulating the economy is complicated business. It therefore seems judicious to consider all regulatory options - including doing nothing - before venturing down this rocky road. Furthermore, my belief in gathering insights from experience - by exploiting natural experiments or, where none exist, by creating policy experiments - has been strengthened. Large scale regulatory interventions should not be merely a response to public outcries or transitory events. 


\section{Literature}

Abadie, A., Diamond, A. and Hainmueller, J. (2010), "Synthetic Control Methods for Comparative Case Studies: Estimating the Effect of California's Tobacco Control Program", in: Journal of the American Statistical Association 105(490), 493-505.

Akerlof, G. A. (1970), "The Market for "Lemons": Quality Uncertainty and the Market Mechanism", in: The Quarterly Journal of Economics 84(3), 488-500.

Angrist, J.D. and Pischke, J.S. (2009), "Mostly Harmless Econometrics: An Empiricist's Companion", in: The Stata Journal 2(4), 358-377.

Bastiat, F. (2007), "The Bastiat Collection (Second Edition)", Auburn: Ludwig von Mises Institute, Part I, “That Which is Seen, and that Which is Not Seen", 1-48.

Bol, T. (2014), "Economic returns to occupational closure in the German skilled trades", in: Social Science Research 46(2014), 9-22.

Bol, T. and Weeden, K. (2014), "Occupational Closure and Wage Inequality in Germany and the United Kingdom”, in: European Sociological Review 19(2014), 1-16.

Branstetter, L., Lima, F, Taylor, L.J. and Venancio, A. (2014), "Do Entry Regulations Deter Entrepreneurship and Job Creation? Evidence from Recent Reforms in Portugal”, The Economic Journal 124(577), 805-832.

Cabral, L. (2012), "Reputation on the Internet", in: M. Peitz and J. Waldfogel (eds.) The Oxford Handbook of the Digital Economy, 343-354.

Damelang, A., Haupt, A. and Abraham, M. (2017), „Economic consequences of occupational deregulation: Natural experiment in the German crafts”, in: Acta Sociologica, 1-16.

Dranove, D. and Jin, G. (2010), "Quality Disclosure and Certification: Theory and Practice", in: Journal of Economic Literature 48(4), 935-963.

Friedman, M. and Kuznets, S. (1954), "Income from Independent Professional Practice”, National Bureau of Economic Research, Inc.

German Federal Statistical Office/Statistisches Bundesamt (downloaded on the $20^{\text {th }}$ of July 2016):

https://www.destatis.de/DE/Publikationen/Thematisch/UnternehmenHandwerk/Handwer kszaehlung/UnternehmenPersonenUmsatz.html 
https://www.destatis.de/DE/Publikationen/Thematisch/Arbeitsmarkt/Erwerbstaetige/Beru fArbeitsbedingungErwerbstaetigen.html

Ippolito, P. and Mathios, A. (1990), "Information, Advertising and Health Choices: A Study of the Cereal Market”, in: American Economic Review 85(2), 91-95.

Kleiner, M (2006), "Licensing Occupations: Ensuring Quality or Restricting Competition?" Kalamazoo, MI: W.E. Upjohn Institute for Employment Research.

Kleiner, M. and Krueger, A. (2010), „The Prevalence and Effects of Occupational Licensing”, in: British Journal of Industrial Relations 48(4), 676-687.

Koch, A. and Nielen, S. (2016), "Oekonomische Effekte der Liberalisierung der Handwerksordnung von 2004”, in: WISO Diskurs 05/2016, Friedrich Ebert Stiftung.

Kreif, N., Grieve, R., Hangartner, D., Turner, A.J., Nikolova, N. and Sutton, M. (2016), "Examination of the Synthetic Control Method for Evaluating Health Policies with Multiple Treated Units", in: Health Economics 25, 1514-1528.

Leamer, E. (1983), "Let's Take the Con Out of Econometrics", in: American Economic Review, 73(1), 31-43.

Leland, H. (1979), "Quarks, lemons and Licensing: A Theory of Minimum Quality Standards", in: Journal of Political Economy, 87(6), 1328-1346.

Lergetporer, P., Ruhose, J. and Simon, L. (2016), „Labor Market Effects of Entry Barriers to Self-Employment: Evidence from Deregulating the German Crafts Sector”, Ifo Center for the Economics of Education, Ifo Institute.

McLaughlin, P. A. (2013), "On the Human Costs of the US Regulatory System: Should Congress Pressure Agencies to Make Rules Faster?", testimony to the Senate Judiciary Committee, Subcommittee on Oversight, Federal Rights and Agency Action.

Nelson, P. (1970), “Information and Consumer Behavior”, in: Journal of Political Economy 78(2), 311-329.

O’Neill, S. Kreif, N., Grieve, R., Sutton, M. and Sekhon, J. (2016), "Estimating casual effects: Considering three alternatives to difference-in-differences estimation", in: Health Services Outcomes Research Methodology 16, 1-21. 
Panhans, M and Singleton, J.D. (2015), “The Empirical Economist's toolkit: From Models to Methods", in: Center for the History of Political Economy (CHOPE) Working Paper No. 2015-03.

Peri, G. and Yasenov, V. (2018), “The Labor Market Effects of a Refugee Wave: Synthetic Control Method Meets the Mariel Boatlift", in: The Journal of Human Resources, published online before print.

Rostam-Afschar, D. (2014), "Regulatory Effects of the Amendment to the HwO in 2004 in German craftsmanship", in: Empirical Economics 47, 1067-1101.

Runst, P. and Thomae, J. (2018), "Does occupational deregulation affect in-company vocational training? - Evidence from the 2004 Reform of the German Trade and Crafts Code, in: Ifh Working Paper Series, No. 14.

Runst, P., Thomä, J., Haverkamp, K. and Müller, K. (forthcoming), “A replication of 'Entry regulation and entrepreneurship: a natural experiment in German craftsmanship", in: Empirical Economics.

Ryan, A.M., Burgess, J.F. and Dimick, J.B. (2015), "Why we shouldn't be indifferent to specification in difference-in-differences models", in: Health Service Research 50(4), $1211-1235$

Salop, S. and Stiglitz, J. (1982), “The Theory of Sales: A Simple Model of Equilibrium Price Dispersion with Identical Agents", in: American Economic Review 72(5), 1121-1130.

Salop, S. and Stiglitz, J. (1977), "Bargains and Ripoffs: A Model of Monopolistically Competitive Price Dispersions", in: Review of Economic Studies 44(3), 493-510.

Stigler, G. (1971), “The Theory of Economic Regulation”, in: The Bell Journal of Economics and Management Science 2(1), 3-21.

Tullock, G. (2004), “The Selected Works of Gordon Tullock, Vol. 1: Virginia Political Economy", edited by Charles K. Rowley. Liberty Fund, Indianapolis.

Varian, H (1980), “A Model of Sales”, in: American Economic Review 70(4), 651-659.

Wilde, L (1980), “The Economics of Consumer Information Acquisition”, in: Journal of Business 53(3), 143-158. 



\section{Chapter II: Masterful Meisters? Voluntary Certification and Quality in the German Crafts Sector}

(with Petrik Runst and Kilian Bizer)

Accepted for publication in German Economic Review.

Download online version: https://onlinelibrary.wiley.com/doi/abs/10.1111/geer.12158 


\begin{abstract}
Voluntary certification systems potentially reduce search costs in markets with imperfect information. Service markets with many heterogeneous firms - such as the crafts market - are prone to information imperfections and can therefore potentially benefit from such informational mechanisms. We examine if the Meister qualification in the German crafts sector improves service quality as perceived by consumers. We find a significant and positive relationship between the Meister title and consumer ratings and conclude that the certificate is a credible sign of quality.
\end{abstract}

JEL Classification: I28, J24, L51

Keywords: Transaction Costs, Search Costs, Voluntary Certification, Service Quality 


\section{Introduction}

In Germany, a reform of the crafts regulation in 2004 - motivated by the aim to increase competition by lowering entry barriers - abolished or lessened the old licensing scheme for a number of crafts trades. In the deregulated trades, the Meister title (an advanced vocational certificate) is now voluntary and no longer a prerequisite to enter the market. Following the reform, popular concerns have been uttered regarding the effectiveness of an optional Meister certificate to safeguard consumer protection in Germany ${ }^{2}$ and some German political parties demand the reintroduction of occupational licensing. ${ }^{3}$

Occupational licensing legislation has indeed been justified by claims of minimum quality protection (Kleiner, 2006). Licensing may in fact be beneficial for consumer protection. For instance, when quality information is not readily available to consumers, or if search costs are prohibitively high, as in the case in markets with strong information failures (see e.g. Akerlof, 1970; and Leland, 1979), as when there is extreme uncertainty over product or service quality as a result of many diverse suppliers being present in the market.

While service markets such as the crafts market may be particularly prone to information imperfections and higher search costs, there are a number of potential mechanisms which could lower search costs for customers, such as advertising, labeling, screening, reputation effects and voluntary certification (see e.g. Ippolito and Mathios, 1990; Dranove and Jin, 2010; and Cabral, 2012), with the latter being the focus of this paper.

We examine whether the optional Meister certificate offers useful information about quality to consumers in German crafts trades, which are no longer subject to a licensing requirement. We estimate the effect of having the Meister certificate on service quality in deregulated crafts trades as perceived by consumers conditional on firm-specific controls. Our finding consistent across all empirical specifications - is that the Meister certification is perceived as a token of quality. We interpret this as a sign that the voluntary certification scheme in deregulated crafts trades reduces information search costs for consumers.

This study is organized as follows. Part two motivates the study by discussing information availability and search costs in the German crafts market, as well as the role of the Meister

\footnotetext{
${ }^{2}$ Traublinger (2014); "Meisterbrief und Meistervoraussetzung: Basis eines starken, innovativen handwerks", in: Ifo Schnelldienst, 16/2014.

3 “CDU will Meisterzwang reanimieren” Handelsblatt, 13.11.2016.
} 
certificate in this context. Part three presents the methodology and the data used. Part four lists the results, before part five concludes by discussing the results from a policy perspective.

\section{Background}

Stiglitz's (2000, p. 1441) essay on the academic contributions of economics of information states that "it is now recognized that information is imperfect, obtaining information can be costly, there are important asymmetries of information, and the extent of information asymmetries is affected by actions of firms and individuals". Our study addresses the cost for consumers related to information procurement, i.e. search costs. The topic is important because economists have shown that market outcomes are sensitive to consumer information acquisition (see e.g. Salop and Stiglitz, 1977, 1982; Varian, 1980 and Wilde, 1980) ${ }^{4}$.

The term "search" was first introduced in the economic literature by Stigler, who depicts it as “canvassing various sellers" (Stigler 1961, p. 213). Nelson (1970) defines "search" as all ways in which consumption options are evaluated. Consumers can search for quality as well as price. This paper focuses on the search for information about quality. Again according to Nelson (1970), information about quality is more costly for consumers to obtain than information about prices.

There are good reasons to believe that high search costs characterize the German crafts market. Service markets such as crafts markets (e.g. hairdresser and optician services or paint jobs) are prone to imperfect information (see e.g. Leland, 1979). First, crafts services are nonstandardized. Quality not only varies among craftsmen but also depends on the specific conditions of the task (e.g. the shape and condition of a roof). In other words, the specific nature of particular tasks makes the search for information about quality costly for consumers. Second, services - as opposed to goods - are purchased before they are provided. This means that consumers cannot observe quality before a purchase, which complicates the search. As it is impossible to assess quality directly, the search process may include indirect sources of information. Examples are other people's evaluations or the checking of educational certificates, such as basic or advanced vocational training degrees. Finally, low frequency purchases, such as house refurbishments, are also associated with higher search costs (see Nelson, 1970).

\footnotetext{
${ }^{4}$ According to Stiglitz (2000, p. 1455), studies on price dispersion under imperfect information "showed that even $[\ldots]$ an epsilon [small] search costs could dramatically change the nature of the market equilibrium".
} 
Information availability and search costs in the German crafts market may have been affected by the deregulation in 2004, which removed the traditional licensing scheme that mandated a Meister degree ${ }^{5}$ (an advanced vocational certificate) for market entry in selected crafts trades. In the affected trades, a voluntary certification scheme has taken its place whereby craftsmen stand free to acquire a Meister degree or not and consumers choose whether or not to purchase from certified craftsmen.

Studies have documented the increased market entry - predominantly of craftsmen without professional qualification - as a result of the reform (see Rostam-Afschar, 2014; RostamAfschar, 2015; Runst et al., 2016; and Koch and Nielen, 2016). Hence, the crafts market is now more competitive and the service providers are more diverse in terms of their formal qualification than before. Theoretically, therefore, the growth in competition may increase consumer surplus by lowering market prices and forcing competitors to strive for higher quality. However, new market entrants and increased supplier diversity may also increase search costs (see Smith et al., 1999). It follows that higher search costs may reduce the positive effects of increased competition.

The effects on consumers of removing occupational licensing appear therefore theoretically undetermined. With regard to the situation in Germany, two points are worth noting. The first point is that "it is unlikely that the number of self-employed will increase in a further deregulation in occupations where the share of self-employment is already quite high" RostamAfschar (2015, p. 21/22). The second point is that various mechanisms that inform consumers may also limit the negative implications of search costs resulting from the de-regulation and market development that has taken place. These include reputations, labeling, minimum quality standards and certification. Our focus is certification and we examine if the 'Meister' certificate can reduce search costs in this market.

Exhaustive economic analysis of the German crafts case has been difficult since there is no avaible data on the quality of the Meister education (see Rostam-Afschar, 2015). This author states that "more evidence on quality and quality uncertainty are needed" (p. 48). Furthermore, it is difficult to rely on evidence from other countries. Empirical studies on professional voluntary certification schemes are scarce and center on the case of teachers in the US (see Kane et al., 2008; Boyd et al., 2007; and Croninger et al., 2007). Since the effects

\footnotetext{
${ }^{5}$ Acquiring the Meister title requires advanced vocational training, which is internationally recognized as tertiary education open only to individuals who have completed apprenticeships or upper secondary vocational schools (see Schneider, 2008, for more information on the German education system).
} 
of certification may be both institution- and market specific, it may not be possible to generalize about them.

There are two channels through which the German Meister certificate - which is easy for consumers to observe - may lower search costs. First of all, higher quality may be a result of higher innate abilities. In this case, the Meister certificate acts as a signal of quality because lower-ability individuals face higher costs in the completion of the qualification and will therefore choose not to pursue this goal (Spence, 1974). According to the signaling hypothesis, the Meister degree does not increase skill, but simply serves as a sorting mechanism. Second, the Meister degree may actually be a productivity enhancing mechanism through which human capital is acquired and individuals become more productive. This is in line with the Becker human capital theory, (see Becker 1964).

In this paper, we estimate the effect of having the Meister certificate on service quality in deregulated crafts trades as perceived by consumers. As stressed in e.g. Caswell and Anders (2009), the effectiveness of certification systems depends on the trust placed in them by consumers. This also depends on existing and significant quality differences between certified and non-certified companies. When this is the case, search costs for consumers are reduced.

\section{Data and methods}

A general lack of attention in the empirical literature on quality effects of professional qualification has been explained by the difficulty in establishing correct measures (see Kleiner, 2000). We use a novel approach to estimate the effects of having a Meister title on service quality as perceived by consumers by exploiting data from an online market platform for crafts services (MyHammer).

Crafts companies sign contracts with MyHammer for a given period and a given price, which varies between the different packages that MyHammer offers. The average contract price is 59 Euros (65 Euros when free trials are excluded), which corresponds to 0.12 Euros per day. The crafts companies can then respond to - and compete for - demands for crafts services that consumers place online. Craftsmen may also be contacted directly by consumers who are interested in the company's profile on the platform. After the job has been completed, consumers can leave an online rating about the crafts company that they employed on MyHammer. 
On entering the platform, craftsmen provide various types of information about their company and activities. MyHammer has provided us with this data - including all customer ratings for all contracts signed from May 1, 2013 to October 29, 2015. For information about when the companies first entered the platform, the data goes back to 2009 .

As we are interested in the effects of voluntary certification, we would like to limit our sample to only deregulated trades. ${ }^{6}$ The activity classification in the data differs from that in the official crafts legislation. Therefore, we proceed by first removing activities with a very high Meister share from the sample (above 80\%). Second, we exclude companies that are not member of a crafts chamber, which is compulsory for crafts companies in Germany. Hence, we exclude from the sample companies that are clearly trades still subject to occupational licensing and companies outside the crafts sector. Furthermore, we remove activity classifications whose names are almost identical to trades that are still subject to licensing in the official crafts legislation. After this data cleaning, we are left with 5,144 firm observations and an average of 35,196 ratings for four indicators of customer satisfaction. Descriptive statistics of our data are presented in table 1.

\footnotetext{
${ }^{6}$ The final sample include the following activities (w/share of Meister-companies in the considered activity classification): "Windows, doors, frames, shutters (23\%)", "tiling (9\%)", "painting, varnishing (39\%)", "various flooring (8\%)" and "interior decoration (12\%)".
} 
Table 1: Descriptive Statistics

\begin{tabular}{|c|c|c|}
\hline & Mean & St.d. \\
\hline Meister & 0.41 & 0.49 \\
\hline Employees 0 & 0.39 & 0.46 \\
\hline Employees 1-3 & 0.39 & 0.49 \\
\hline Employees 4-9 & 0.18 & 0.34 \\
\hline Employees 10-20 & 0.04 & 0.15 \\
\hline Employees 21+ & 0.01 & 0.09 \\
\hline Einzelunternehmen (fully liable) & 0.84 & 0.37 \\
\hline GmbH (limited liability) & 0.08 & 0.26 \\
\hline UG (limited liability) & 0.02 & 0.15 \\
\hline GbR (full liability) & 0.04 & 0.19 \\
\hline Other & 0.02 & 0.14 \\
\hline Foundation year & 2006 & 12.68 \\
\hline Employing a trainee & 0.04 & 0.19 \\
\hline Liability insurance & 0.09 & 0.28 \\
\hline Entry in 2009 & 0.03 & 0.16 \\
\hline Entry in 2010 & 0.11 & 0.32 \\
\hline Entry in 2011 & 0.08 & 0.27 \\
\hline Entry in 2012 & 0.08 & 0.27 \\
\hline Entry in 2013 & 0.20 & 0.40 \\
\hline Entry in 2014 & 0.30 & 0.45 \\
\hline Entry in 2015 & 0.21 & 0.41 \\
\hline Overall Rating & 2.61 & 0.35 \\
\hline Quality Rating & 4.64 & 0.39 \\
\hline $\mathbf{N}$ & $5,144 *$ & \\
\hline
\end{tabular}

According to the German Federal Statistical Office, overall there were 578,013 crafts companies in Germany in 2013, which means that our full sample is a mere 1 percent of the overall population. We have used the official crafts data to assess the representativeness of our sample (see table 2). For most variables, our sample is true for the overall population. Exceptions are the average age of the companies, which is much younger in our sample, and the qualification level, which is much lower in our sample. 
Table 2: Sample representativeness

\begin{tabular}{l|l|l} 
Share of & MyHammer & Overall population \\
\hline Meister & $41 \%$ & $75 \%$ \\
\hline Employees 0 & $39 \%$ & $28 \%$ \\
Employees 1-3 & $39 \%$ & $33 \%$ \\
Employees 4-9 & $18 \%$ & $20 \%$ \\
Employees 10-20 & $4 \%$ & $11 \%$ \\
Employees 21+ & $1 \%$ & $7 \%$ \\
Einzelunternehmen (fully liable) & $84 \%$ & $67 \%$ \\
GmbH (limited liability) & $8 \%$ & $23 \%$ \\
UG (limited liability) & $2 \%$ & $1 \%$ \\
GbR (full liability) & $4 \%$ & $8 \%$ \\
Other & $2 \%$ & $1 \%$ \\
\hline Foundation after 2004 & $72 \%$ & $28 \%$ \\
Employing a trainee & $4 \%$ & $14 \%$ \\
\hline N & $5,144 *$ & 583,668
\end{tabular}

\subsection{Main variables}

Altogether, there are four rating variables in the dataset. These are an overall rating variable and three specific rating variables where the customer judges quality, friendliness and reliability. For the overall rating variable, the customer can give a "negative", "neutral" or "positive" rating of the service rendered, which we numerate on an ordinal scale from 1 to 3. The more specific ratings are scaled from 1 to 5 , with one being the least content and five the most content. Figure 1 shows the distribution of the ratings. Only about one-third of the companies have received a rating and the number of ratings per company varies from 1 to 601 , with a mean of 11 ratings (see figure 2). 
Figure 1: The number of ratings per company

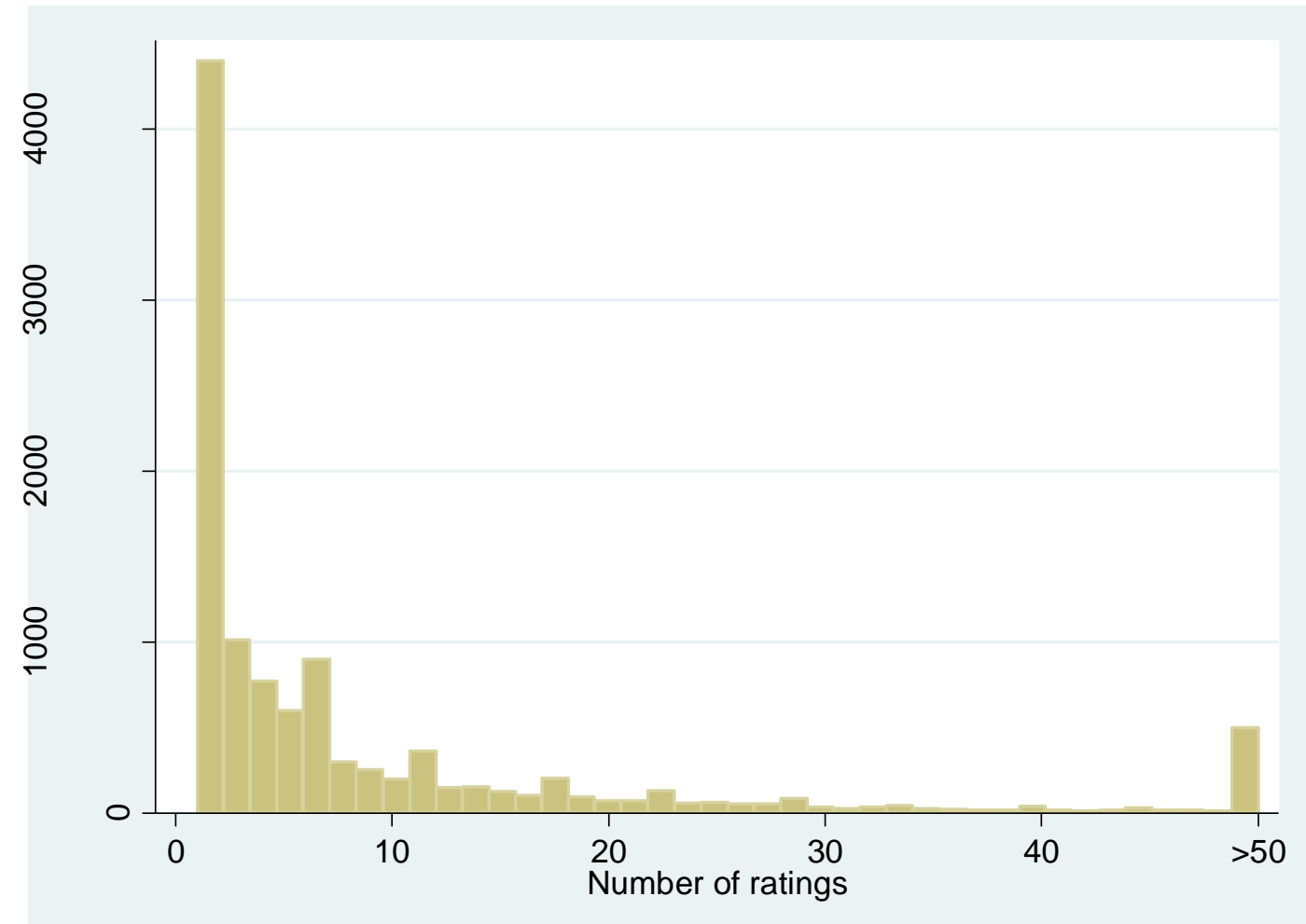

Figure 2: The distribution of the rating variables

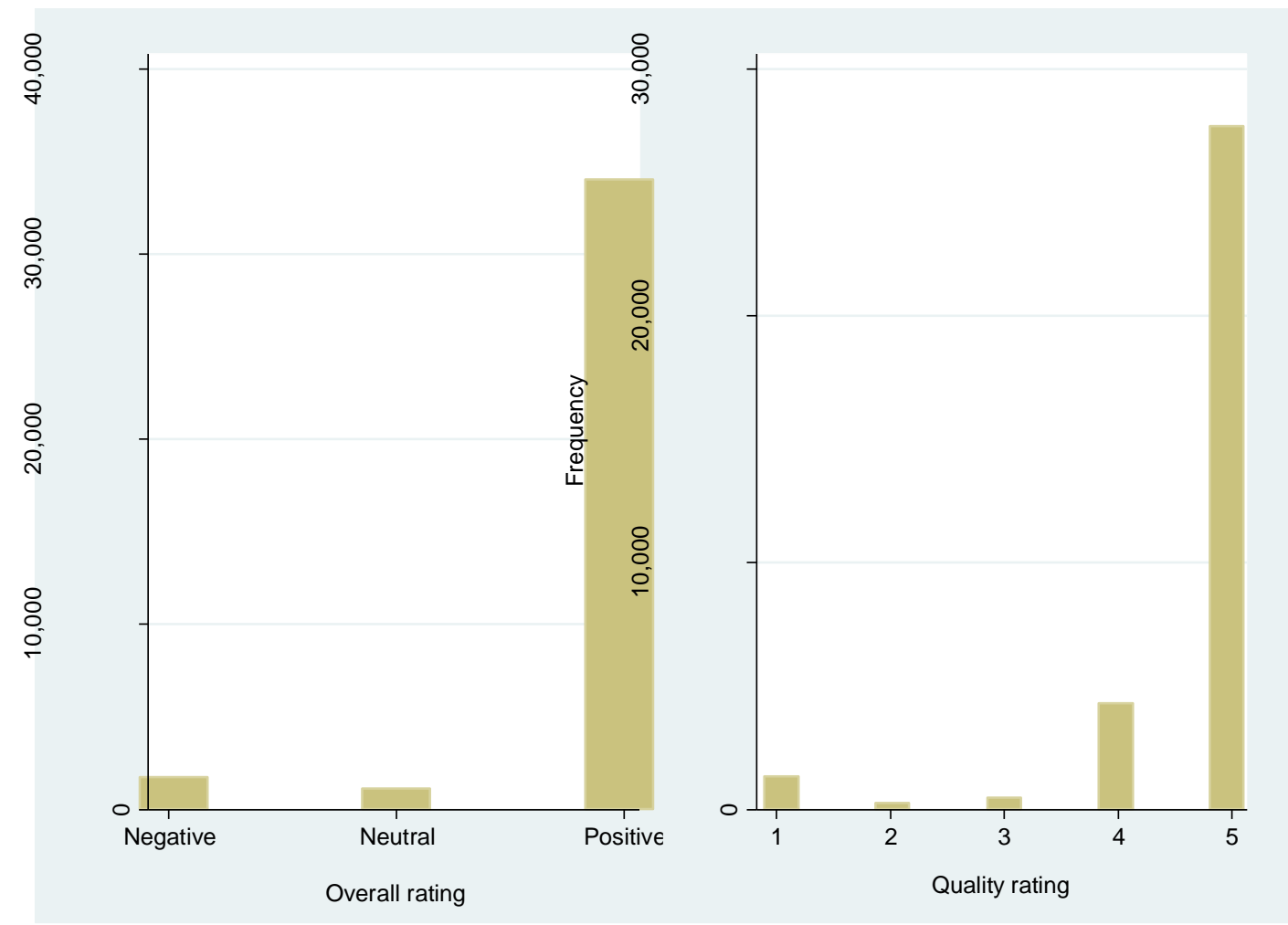


Given that using online ratings to overcome the problem of measuring quality is an innovative approach, we expect - and therefore pre-empt - certain questions related to the meaningfulness of our dependent variable. Strategic manipulation (discussed in e.g. Dellarocas, 2003) can occur in theory, whereby online reviews are falsified or online identities are misused. However, since MyHammer only permits consumers who have had interactions with craftsmen on the platform to submit a rating, this problem is substantially reduced. ${ }^{7}$ There may also be quality aspects that are unobservable to consumers or only become visible over time. However, our data measures short- and medium-term quality observable to consumers. It is reasonable to expect a strong correlation between observed and unobserved quality, although this correlation cannot be calculated.

The order of ratings may also have an influence on the average quality rating, given that a negative first review may prevent subsequent sales and hence yield a lower average rating than would have been the case with a positive initial rating and subsequent accumulation. This problem is diminished by the fact that high-quality companies have a higher probability of obtaining a positive first review compared with low-quality companies and are, therefore, more likely to keep accumulating ratings. In this way, the influence of one negative review on the average outcome is reduced.

The qualification variable is constructed by MyHammer based on documents provided by the companies (Meister certificate if they have it and/or membership in a local crafts chamber ${ }^{8}$ ). Altogether, one-quarter of the companies in the sample have the Meister certification.

We use a variety of empirical estimations to explore the data, namely a linear regression model, a random effects ordered logit model, a negative binomial model, a truncated regression model and finally survival analysis.

\subsection{Initial models}

We start our data analysis with a cross-sectional linear regression where the dependent variable is the average rating obtained by each firm. The independent variable of interest is the qualification variable (having a Meister title or not). Additionally, we control for the number of employees, the legal status, the year of firm establishment as well as the year of

\footnotetext{
${ }^{7}$ We conduct robustness checks where we exclude all companies from the sample that have three or less ratings, which does not change the results.

${ }^{8}$ Not all companies using MyHammer are crafts companies.
} 
entry onto the online platform, having liability insurance and employing a trainee. We also include regional and sector controls. The sector controls are important since we estimate an average effect over a range of different crafts activities, i.e. heterogeneous markets. For the same reason, we calculate clustered standard errors since our observations are likely to be correlated within certain groups (i.e. type of activity).

We continue the data analysis with a random effects ordered logit model. Here, the data is organized as a panel where the time dimension is the sequence of consumer ratings and the dependent variable is each rating obtained by each firm on either a 1-3 Likert scale (in the case of the overall rating variable) or a 1-5 Likert scale (in the case of the specific rating variables). The independent variable of interest is again the Meister qualification variable and the controls are identical to those in the cross-sectional linear regressions. Again, we calculate cluster-robust standard errors.

The advantage of using a panel specification is that by including each rating, as opposed to calculating an average rating, we remain true to the original format of the dependent variable, as well as having many more observations than in our linear model. Since the activity classification in the dataset is relatively broad (each type of activity contains several distinct crafts trades), the sector controls are unlikely to capture all market-specific effects and therefore unobserved heterogeneity is likely to be present in our model. The random effects ordered logit approach models unobserved heterogeneity as a function of time-invariant characteristics, including time-averaged regressors, with an additive error term that is assumed to be independent of the model's covariates (see e.g. Muris, 2016).

If voluntary certification actually increases quality as perceived by consumers, high-quality Meister companies (especially market incumbents) may not have such a strong need to build a high quality reputation via online ratings. This might explain why Meister companies are under-represented on MyHammer in the first place. We estimate a negative binomial model where the dependent variable is the total number of consumer ratings received by each firm to ascertain whether there is a difference in rating accumulation among Meister and non-Meister companies.

An important limit to these initial models stems from the skewness of the rating variables. Few poor ratings ${ }^{9}$ in the data mean little variation in our sample. It is also likely to mean that

\footnotetext{
${ }^{9}$ For instance, the mean scores for the three specific rating variables were 4.7, 4.6 and 4.6, respectively.
} 
our sample is not fully representative of the quality of German crafts services. There are strong reasons to suspect that poor performers are under-represented. Resnick et al. (2006) study reputation effects on eBay and note that consumers only tend to rate when they are satisfied as sellers' ratings are positive $99 \%$ of the time. Furthermore, quality-related selection mechanisms may be at work. Company owners who consider their own quality to be low may not enter the MyHammer platform in the first place because low ratings will lead to fewer contracts (self-selection). Poor-quality companies that choose to enter the platform are likely to realize the sanctioning effect of customer ratings relatively quickly and leave after a short time (market selection), whereas companies providing higher quality services are likely to stay longer on the platform.

Since issues related to selection effects are likely to appear in our sample, we proceed by estimating a truncated regression model, which is appropriate in cases where observations above or below a given threshold are systematically excluded from the sample. We also supplement with a survival model that - instead of looking at ratings - identifies the factors that influence the total time spent on the platform by each company.

\subsection{Extensions}

In the presence of self-selection, low-quality companies are likely never to enter the MyHammer platform. A common method in the literature addressing sample selection bias is the Heckman selection model (see Heckman, 1976). However, in our case the Heckman twostep estimator is not feasible since we have no information about the truncated observations. Instead, we estimate a simple truncated model, which is appropriate when sample data is only obtained for a subset (in our case, higher quality companies) of the true population (in our case, both high- and low-quality companies) (see e.g. Greene, 2008). We use the same setup for our truncated model as for the linear regression model, meaning that the dependent variable is the average consumer rating obtained by each firm.

In our case, truncation due to any self-selection happens from below since the probability of being on MyHammer should decrease with the prospect of accumulating bad ratings. However, there is no predetermined quality level at which the truncation begins. Therefore, we estimate multiple truncated regression models where the truncation begins at different values. The ratings on MyHammer are scaled from 1-3 (overall rating) or 1-5 (quality rating). Altogether, $92 \%$ of consumers have given the top overall rating (3) and $94 \%$ of consumers 
have given the two best quality ratings ( 4 and 5). Therefore, we use both 1 and 2 as the lower bound for the overall rating variable and 1,2 and 3 as the lower bound for the quality rating variable.

In the presence of market selection, high-quality crafts companies are more likely to continue using the MyHammer platform. By changing our dependent variable from customer ratings to the number of days spent on the MyHammer platform, we can use survival analysis to estimate the effects of the covariates from the previous specifications, particularly the qualification variable. We are able to improve our observation number by including companies that have never been rated in the sample.

The focus of survival analysis is time-to-event (in our case, the number of days between the date when crafts companies enter the MyHammer platform and the date when they leave). We calculate the Kaplan-Meier survival function, defined as $S(t)=1-F(t)=P(T \geq t)$, which is the probability of surviving past time $t$ (see e.g. Wooldridge, 2002). In order to estimate the effect of the Meister title, we calculate common parametric survival models (i.e. Exponential, Weibull and Gompertz regression coefficients. We control for company size, legal status, the year of firm establishment as well as having liability insurance and employing a trainee. Again, we also include regional and sector controls.

Censoring - defined in Cleves et. al (2010, p. 29) as "when the failure event occurs and the subject is not under observation" - is a challenge in survival analysis. Right-censoring happens when subjects do not experience the event (here leaving the MyHammer platform) within the duration of our study (see Cleves et. al, 2010). This is a common case and does not pose a problem for the validity of results as long as the censoring is independent of the probability of the event (see Prinja et al., 2010). We consider that the assumption of independent right-censoring holds in our case. Left-censoring happens when the event occurs prior to the subject entering the study (see Cleves et al., 2010). In our case, this is not a problem since the observation period for each company begins at the date when it enters the MyHammer platform.

As before, we fear unobserved heterogeneity in our data. It has been shown that the influence of the observed covariate is underestimated when the presence of omitted covariates is ignored (see e.g. Chamberlain, 1985). As suggested by Jenkins (2008), we therefore run a frailty-model assuming both a Gamma and an inverse Gaussian distribution - as is commonly used for continuous time models. However, since the relevant likelihood ratio test does not 
reject the null hypothesis that the frailty component equals zero, we also present estimates using the non-frailty model.

\section{Results}

\subsection{Masterful Meisters}

Basic descriptive statistics of our dataset suggest a positive association between our qualification variable and our rating variables. Among the companies that have an overall rating above the mean (2.7), 20 percent have the Meister certification. In comparison, the share of certified companies among those that have very low ratings (below 1.5) is 0.2 percent. All of our empirical models confirm this intuition.

We discuss the linear model and the random effect ordered logit model together as they yield similar results. To facilitate the reading of the result tables, we only show the results for the overall rating variable as well as the quality rating variable as dependent variables, although the results for the other specific rating variables are consistent with the results presented. ${ }^{10}$

\footnotetext{
${ }^{10}$ Furthermore, estimations conducted using the full sample of all companies on MyHammer regardless of sector (also not presented) tell a similar story, albeit with slightly higher and more significant effect sizes.
} 
Table 3: Linear regression model

\begin{tabular}{l|l|l} 
& $\begin{array}{l}\text { Overall } \\
\text { rating }\end{array}$ & $\begin{array}{l}\text { Quality } \\
\text { rating }\end{array}$ \\
\hline Meister & $0.04^{* *}$ & $0.08^{*}$ \\
\hline Employees 1-3 & $-0.03^{*}$ & -0.04 \\
Employees 4-9 & $-0.19^{* * *}$ & $-0.16^{* * *}$ \\
Employees 10-20 & -0.10 & $-0.30^{*}$ \\
Employees 21+ & -0.15 & $-0.74^{*}$ \\
GmbH (limited liability) & -0.05 & -0.08 \\
UG (limited liability) & $-0.12^{*}$ & -0.13 \\
GbR (full liability) & -0.02 & 0.01 \\
Other & -0.06 & -0.15 \\
\hline Sector controls & Yes & Yes \\
Geographical controls & Yes & Yes \\
Foundation year & -0.00 & -0.00 \\
Liability insurance & 0.03 & 0.03 \\
Employing a trainee & 0.00 & -0.07 \\
Entry in 2010 & -0.01 & -0.05 \\
Entry in 2011 & 0.04 & -0.04 \\
Entry in 2012 & 0.05 & 0.02 \\
Entry in 2013 & 0.04 & 0.01 \\
Entry in 2014 & 0.08 & 0.09 \\
Entry in 2015 & $0.07 * *$ & 0.10 \\
Number of reviews & 0.00 & 0.00 \\
\hline R-square adjusted & 0.02 & 0.02 \\
N & 1,928 & 1,883 \\
\hline
\end{tabular}

$*, * * * * *$ correspond to 10,5 , and 1 percent levels of statistical significance.

Qualification consistently has a significant impact on ratings. The linear estimate of our Meister variable OLS varies from 0.04 to 0.08 , meaning that having a Meister in the company adds 0.04 to 0.08 to the average consumer rating obtained (see table 3 ). While this may seem like a small effect size, one must keep in mind that most ratings made are between 2 to 3 (overall rating) and 4 to 5 (quality rating). The logit estimates for the qualification variable are also significant (see table 4). According to the average marginal effect calculations, Meister companies have a $2 \%$ higher probability of achieving the best overall rating and a $3 \%$ higher probability of achieving the best quality rating (see table 5). It is interesting to note that Meister companies have a lower probability of achieving the second-best quality rating, meaning that they appear to deliver the very best in terms of quality. In terms of the predicted probabilities of achieving a given rating (displayed in table 6), a first observation is that independent of qualification companies have a very high probability of achieving the best 
rating, which is a result of the skewness of the rating variable. However, there is a difference ${ }^{11}$ in the predicted probabilities according to qualification. Meister companies have a 93\% chance of achieving the best overall rating as opposed to $91 \%$ for non-Meister companies, while they have $83 \%$ chance of achieving the best rating as opposed to $80 \%$ for non-Meister companies.

Table 4: Random effects ordered logit model

\begin{tabular}{|c|c|c|}
\hline & $\begin{array}{l}\text { Overall } \\
\text { rating }\end{array}$ & $\begin{array}{l}\text { Quality } \\
\text { rating }\end{array}$ \\
\hline Meister & $0.32 * *$ & $0.21 * *$ \\
\hline Employees 1-3 & $-0.45^{* *}$ & $-0.15^{*}$ \\
\hline Employees 4-9 & $-0.88 * * *$ & $-0.49 * * *$ \\
\hline Employees 10-20 & $-1.40 * * *$ & $-0.78 * * *$ \\
\hline Employees 21+ & $-0.51 * *$ & $-1.24 *$ \\
\hline GmbH (limited liability) & -0.27 & -0.29 \\
\hline UG (limited liability) & $-0.86^{* *}$ & $-0.42 *$ \\
\hline GbR (full liability) & -0.27 & -0.01 \\
\hline Other & $-0.88 * *$ & $-0.41 *$ \\
\hline Sector controls & Yes & Yes \\
\hline Geographical controls & Yes & Yes \\
\hline Foundation year & -0.01 & 0.00 \\
\hline Liability insurance & 0.24 & 0.09 \\
\hline Employing a trainee & -0.18 & 0.10 \\
\hline Entry in 2010 & -0.07 & 0.04 \\
\hline Entry in 2011 & 0.14 & -0.24 \\
\hline Entry in 2012 & -0.01 & -0.11 \\
\hline Entry in 2013 & 0.10 & -0.01 \\
\hline Entry in 2014 & $0.59 * *$ & 0.21 \\
\hline Entry in 2015 & $0.66 * *$ & $0.28 *$ \\
\hline Number of reviews & 0.00 & -0.00 \\
\hline Prob >chi2 & 0.00 & 0.00 \\
\hline Cut1 & -23.79 & 0.78 \\
\hline Cut2 & -23.18 & 1.00 \\
\hline Cut3 & & 1.28 \\
\hline Cut4 & & 2.69 \\
\hline $\mathbf{N}$ & 29,863 & 27,619 \\
\hline
\end{tabular}

$*, * *, * * *$ correspond to 10,5 , and 1 percent levels of statistical significance.

\footnotetext{
${ }^{11}$ Equal to the estimate of the qualification variable in table 5.
} 
Table 5: Random effects ordered logit model: Average marginal effects

\begin{tabular}{|c|c|c|c|c|c|c|c|c|}
\hline & \multicolumn{3}{|c|}{ Overall rating } & \multicolumn{5}{|c|}{ Quality rating } \\
\hline & Rating=1 & Rating $=2$ & Rating $=3$ & Rating=1 & Rating $=2$ & Rating=3 & Rating $=4$ & Rating $=5$ \\
\hline Meister & $-0.01 * *$ & $-0.01 * *$ & $0.02 * *$ & $-0.01 * *$ & $-0.00 * *$ & $-0.00 * *$ & $-0.02 * *$ & $0.03 * *$ \\
\hline Employees 1-3 & $0.02 * *$ & $0.01 * *$ & $-0.03 * *$ & $0.01 *$ & $0.00 *$ & $0.00^{*}$ & $0.01 *$ & $-0.02 *$ \\
\hline Employees 4-9 & $0.04 * * *$ & $0.01 * * *$ & $-0.05^{* * *}$ & $0.02 * * *$ & $0.00 * * *$ & $0.00^{* * *}$ & $0.04 * * *$ & $-0.07 * * *$ \\
\hline Employees 10-20 & $0.06^{* * *}$ & $0.02 * * *$ & $-0.08 * * *$ & $0.03^{* * *}$ & $0.01 * * *$ & $0.01 * * *$ & $0.06^{* * *}$ & $-0.11 * * *$ \\
\hline Employees 21+ & $0.06 * *$ & $0.02 * *$ & $-0.08 * *$ & $0.05^{* * * *}$ & $0.01 * * *$ & $0.01 * * *$ & $0.10^{* * *}$ & $-0.17 * *$ \\
\hline GmbH (limited liability) & 0.01 & 0.00 & -0.02 & 0.01 & 0.00 & 0.00 & 0.02 & -0.04 \\
\hline UG (limited liability) & 0.01 & 0.00 & -0.02 & $-0.02 *$ & 0.00 & $0.01 *$ & $0.03 *$ & $-0.06^{*}$ \\
\hline GbR (full liability) & $0.04 * *$ & $0.01 * *$ & $-0.05 * *$ & 0.00 & 0.00 & 0.00 & 0.00 & -0.00 \\
\hline Other & $0.04 * *$ & $0.01 * *$ & $-0.05 * *$ & 0.02 & 0.00 & $0.00 *$ & $0.03 *$ & $-0.06^{*}$ \\
\hline Sector controls & Yes & Yes & Yes & Yes & Yes & Yes & Yes & Yes \\
\hline Geographical controls & Yes & Yes & Yes & Yes & Yes & Yes & Yes & Yes \\
\hline Foundation year & 0.00 & 0.00 & -0.00 & -0.00 & -0.00 & -0.00 & -0.00 & 0.00 \\
\hline Liability insurance & -0.01 & -0.00 & 0.01 & -0.00 & -0.00 & -0.00 & -0.01 & 0.01 \\
\hline Employing a trainee & 0.01 & 0.00 & -0.01 & -0.00 & -0.00 & -0.00 & -0.01 & 0.01 \\
\hline Entry in 2010 & 0.00 & 0.00 & -0.00 & -0.00 & -0.00 & -0.00 & -0.00 & 0.01 \\
\hline Entry in 2011 & -0.01 & -0.00 & 0.01 & 0.01 & 0.00 & 0.00 & 0.02 & -0.03 \\
\hline Entry in 2012 & 0.00 & 0.00 & -0.00 & 0.00 & 0.00 & 0.00 & 0.01 & -0.02 \\
\hline Entry in 2013 & -0.00 & -0.00 & 0.01 & 0.00 & 0.00 & 0.00 & 0.00 & -0.00 \\
\hline Entry in 2014 & -0.02 & -0.01 & 0.03 & -0.01 & -0.00 & -0.00 & -0.02 & 0.03 \\
\hline Entry in 2015 & $-0.03^{* *}$ & $-0.01 * *$ & $0.04 * *$ & $-0.01 *$ & -0.00 & $-0.00^{*}$ & $-0.02 *$ & $0.04 *$ \\
\hline Number of reviews & 0.00 & 0.00 & -0.00 & 0.00 & 0.00 & 0.00 & 0.00 & $-0.06^{*}$ \\
\hline
\end{tabular}

$*, * *, * * *$ correspond to 10,5 , and 1 percent levels of statistical significance.

Table 6: Random effects ordered logit model: Predicted outcomes

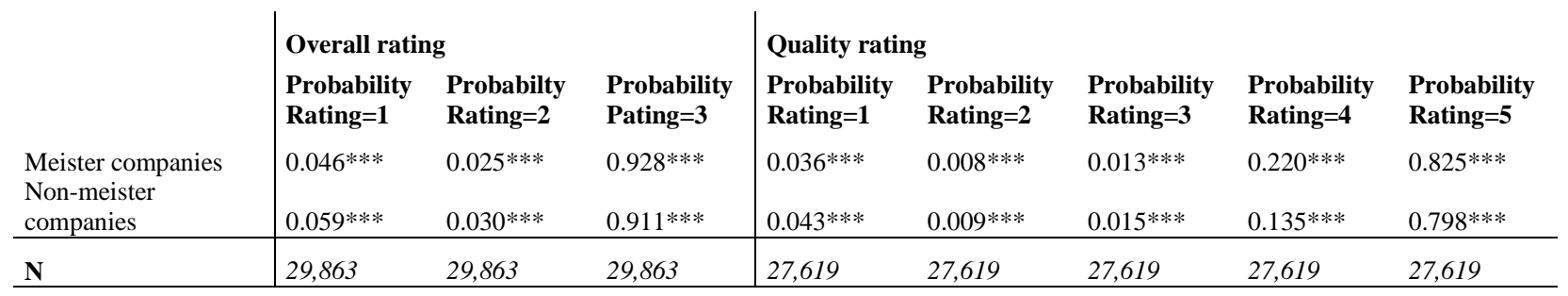

$*, * *, * * *$ correspond to 10,5 , and 1 percent levels of statistical significance.

Turning to the control variables, employing one or more additional workers affects customer satisfaction negatively. An explanation resembling a principal-agent problem could be put forward for this result. That is that smaller companies are more transparent and each person feels more responsible for the company and therefore has higher incentives to be concerned with quality service provision. 
Furthermore, the companies' legal form appears to matter for customer ratings (at least in the logit model). Being an $U G$ (stock corporation) has a mostly significant and negative effect on ratings relative to the comparison group, which is Einzelunternehmen (sole trader or sole proprietorship). The effect of being a $\mathrm{GmbH}$ (private limited company) seems to proceed in the same direction. We find that this result is reasonable given that sole traders or proprietors are held 100 percent personally liable for the financial situation of the company. As such, they will have an additional incentive to be concerned with service quality. The effect of being a $G b R$ (a company constituted under civil law) is mostly insignificant, corroborating our explanation as the owners of such companies also stand personally financially liable.

The variables for the geographical location of the company, the year when it was founded, whether it employs trainees, whether it has liability insurance as well as the number of ratings it has received on MyHammer are not significant. The fact that the foundation year proved insignificant should reduce concerns related to sampling as the main difference between MyHammer companies and the rest of German crafts companies is the companies' age.

Furthermore, having a Meister has a significant and negative effect on rating accumulation (see table 7), although the size of the estimate is very small, with Meister companies accumulating on average half a rating less. This is consistent with the finding that certification affects quality as perceived by consumers. In this case, certified companies are less dependent on reputation mechanisms to fill their order books. The advantage that online platforms offer such companies is primarily to obtain first contact with consumers. The experience of the MyHammer management is that, in a number of cases, the interaction between craftsmen and consumers quickly goes offline. This explains the low consumer propensity to ultimately rate companies online. 
Table 7: Negative binomial model, number of ratings as dependent variable

\begin{tabular}{l|l} 
Meister & $-0.43 * * *$ \\
\hline Employees 1-3 & 0.03 \\
Employees 4-9 & 0.04 \\
Employees 10-20 & $-0.79 * * *$ \\
Employees 21+ & 0.83 \\
GmbH (limited liability) & 0.06 \\
UG (limited liability) & 0.02 \\
GbR (full liability) & $-0.48 * * *$ \\
Other & -0.21 \\
\hline Sector controls & Yes \\
Geographical controls & Yes \\
Foundation year & $0.01 * *$ \\
Liability insurance & -0.16 \\
Employing a trainee & 0.13 \\
Entry in 2010 & 0.30 \\
Entry in 2011 & -0.12 \\
Entry in 2012 & 0.29 \\
Entry in 2013 & -0.07 \\
Entry in 2014 & -0.35 \\
Entry in 2015 & -0.89 \\
\hline Prob >chi2 & 0.00 \\
N & 1,928 \\
\hline$* * * * *$ correspond to 10, 5, and 1 percent levels of statistical significance \\
\hline
\end{tabular}

Our suspicion of selection effects seems to be corroborated by the data. Estimates for the "entry-year" variable show that in comparison to companies that entered in 2009, those that entered in the latest years (2014 and 2015) appear to achieve higher customer satisfaction. This is in accordance with the theory that with more experience using the platform, crafts companies will only choose to enter if they deem their services on par with customer expectations, as the self-selection hypothesis predicts. Furthermore, in line with the market selection hypothesis, companies with no ratings spend the lowest average time on MyHammer, followed by those with very low ratings (overall rating below 1.5). By contrast, companies with an above-average overall customer rating (>2.8) stay on MyHammer for an above-average length of time.

Therefore, we complement our findings with results from a truncated regression model (which addresses the problem of self-selection) and a survival model (which addresses the problem of market selection). 


\subsection{Allowing for selection}

The results from the truncated regression model shown in table 8 are overall consistent with the findings in the previous models. With a lowest truncation limit of 1 , the number of truncated observations is 24 for the regression with the overall rating as the dependent variable. It is 29 for the regression with the quality rating as the dependent variable. With 2 as the lower bound, 98 and 43 observations are truncated, whereas 83 quality ratings are truncated when 3 is our lower bound. In all cases, both the sign and the size of the estimates are similar to the linear cross-section estimates. Most importantly, qualification still has a positive and significant impact on ratings, with an effect size ranging from a 0.02 to 0.07 higher average consumer rating.

Table 8: Truncated regression model

\begin{tabular}{l|l|l|l|l|l} 
& \multicolumn{2}{|l}{ Lower limit=1 } & \multicolumn{2}{l}{ Lower limit=2 } & \multicolumn{2}{l}{$\begin{array}{l}\text { Lower } \\
\text { limit=3 }\end{array}$} \\
\hline & Overall rating & Quality rating & Overall rating & Quality rating & Quality rating \\
\hline Meister & $0.03^{*}$ & $0.07^{* *}$ & $0.02^{* * *}$ & $0.07 * * *$ & $0.05^{* * *}$ \\
\hline Employees 1-3 & -0.02 & -0.04 & $-0.02^{* * *}$ & -0.03 & $-0.03^{*}$ \\
Employees 4-9 & $-0.05^{* *}$ & $-0.11^{* *}$ & $-0.04^{* * *}$ & $-0.07 *$ & $-0.08^{* * *}$ \\
Employees 10-20 & -0.10 & -0.18 & -0.02 & -0.13 & $-0.15^{* *}$ \\
Employees 21+ & -0.16 & -0.42 & 0.01 & -0.05 & -0.11 \\
GmbH (limited liability) & -0.02 & -0.10 & -0.00 & -0.06 & -0.02 \\
UG (limited liability) & $-0.15^{* *}$ & -0.18 & $-0.15^{* *}$ & -0.02 & -0.06 \\
GbR (full liability) & 0.02 & -0.00 & -0.04 & -0.07 & -0.00 \\
Other & -0.09 & -0.11 & -0.07 & -0.13 & -0.12 \\
\hline Sector controls & Yes & Yes & Yes & Yes & Yes \\
Geographical controls & Yes & Yes & Yes & Yes & Yes \\
Foundation year & -0.00 & $-0.00^{* *}$ & $-0.00^{* * *}$ & $-0.00^{* *}$ & $-0.00^{* *}$ \\
Liability insurance & $-0.03^{*}$ & 0.02 & $0.02^{*}$ & 0.02 & $0.05^{* *}$ \\
Employing a trainee & 0.00 & -0.04 & -0.02 & -0.09 & -0.06 \\
Entry in 2010 & 0.01 & -0.00 & 0.00 & -0.05 & -0.01 \\
Entry in 2011 & 0.03 & -0.06 & -0.01 & -0.08 & -0.06 \\
Entry in 2012 & 0.04 & -0.05 & -0.02 & -0.09 & -0.06 \\
Entry in 2013 & 0.03 & -0.01 & -0.00 & -0.04 & 0.01 \\
Entry in 2014 & 0.06 & 0.06 & 0.02 & 0.01 & 0.04 \\
Entry in 2015 & 0.07 & 0.06 & 0.02 & 0.03 & 0.05 \\
Number of reviews & -0.00 & -0.00 & $0.00^{* * *}$ & $-0.00 * *$ & $-0.00^{* * *}$ \\
\hline Prob >chi2 & 0.00 & 0.00 & 0.00 & 0.00 & 0.00 \\
N & 1,904 & 1,852 & 1,830 & 1,902 & 1,800 \\
\hline
\end{tabular}

$*, * *, * * *$ correspond to 10,5 , and 1 percent levels of statistical significance. 
Turning to the survival analysis, there are visible threshold effects in the survival function with steep declines in survival rates after 90 and 455 days (see figure 3), meaning that many companies stay for this duration on the platform. This finding is explained by the type of contracts that MyHammer offers. The MyHammer starter packet - which lasts for three months - is meant as a test before a greater commitment to a longer duration contract. Thereafter, MyHammer offers one-year contracts. After one year and three months, the survival function takes a smoother shape.

Figure 3: The survival function

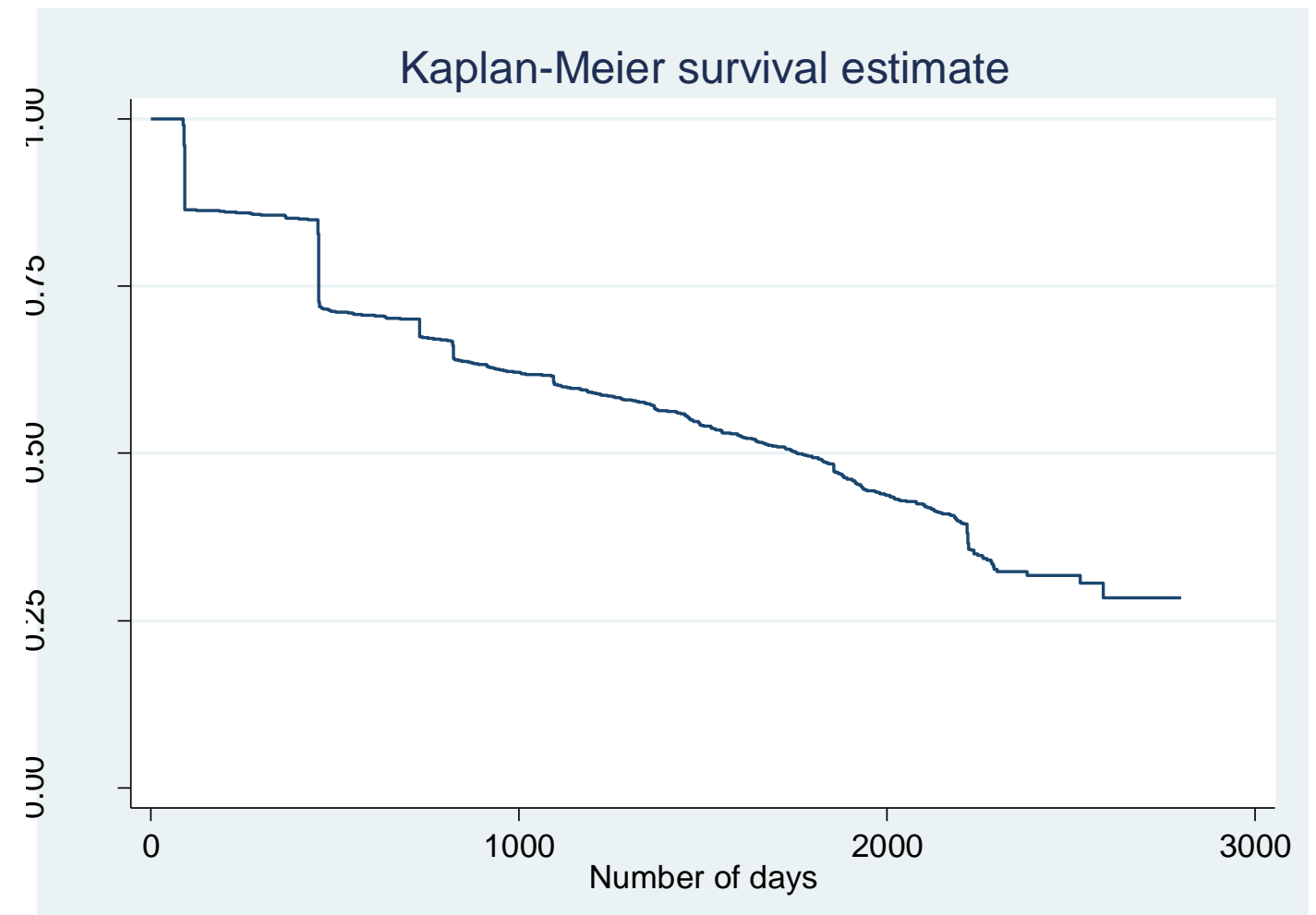


Figure 4: The survival function by group

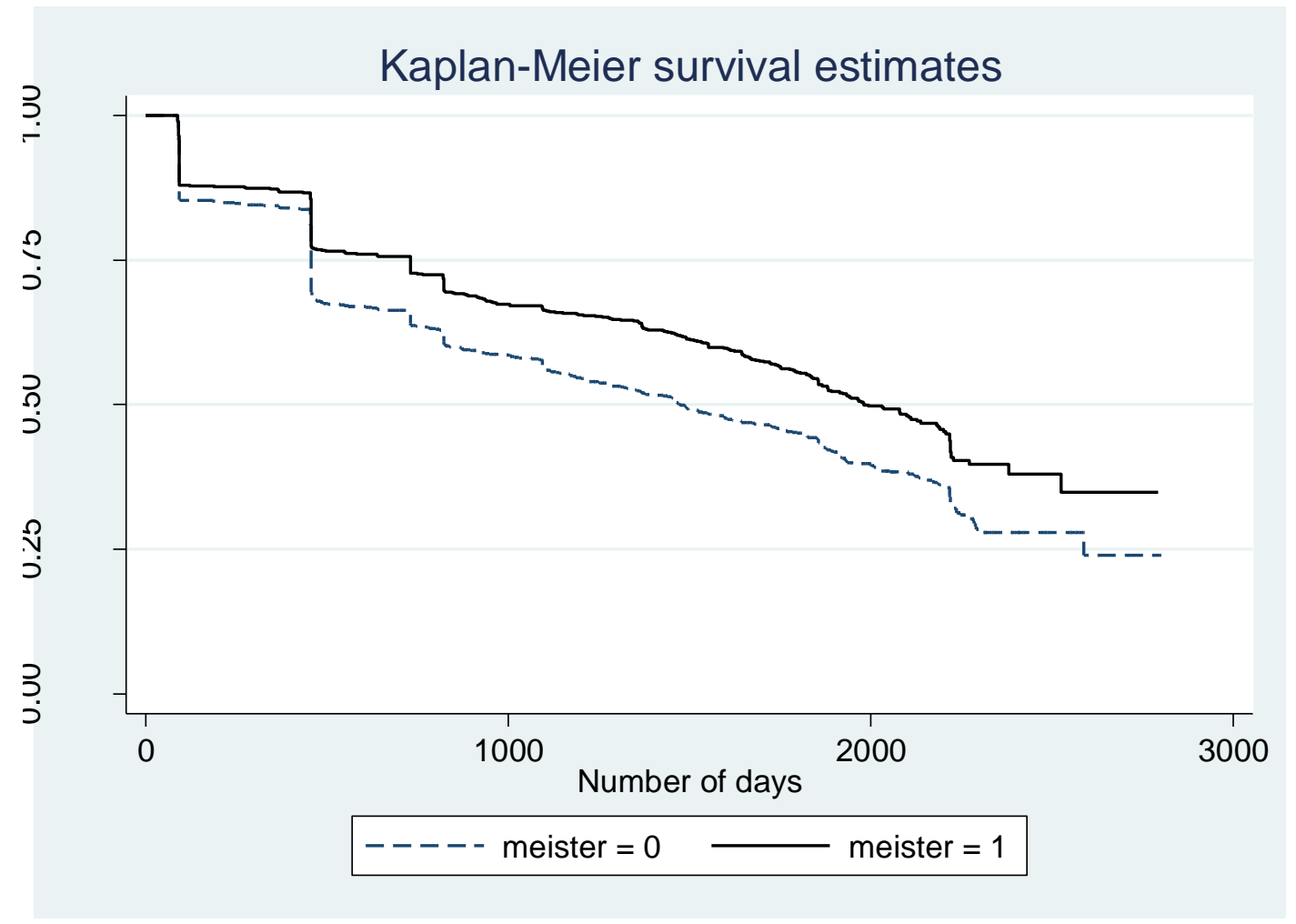

The Kaplan-Meier function by group shows that qualification clearly matters for survival. As can be seen in figure 4, the survival estimate for companies with a Meister employed is noticeably above that of non-Meister companies and the statistical significance of this difference is confirmed through a $\mathrm{Chi}^{\wedge} 2$-test for the equality of survival functions between two groups. It appears that the advantage of having a Meister holds in particular for durations above approximately 90 days. We interpret this as further evidence in favor of the presence of a selection mechanism, since positive ratings for high quality take some time to accumulate and have an effect on the company's wish to stay on the platform.

The higher survival chance for Meister companies is corroborated by our parametric estimations shown in table 8. The margins estimates shown are the difference in median survival time with respect to the comparison group. We see that the median survival time for Meister companies is higher than that of non-Meister companies or - put differently - having a Meister significantly increases the chances of staying on the platform. The statistical significance of the results is similar across all models, both with and without frailty, although there is some variation in effect sizes. The estimated coefficients mainly range between 200 
and 300 days. ${ }^{12}$ This means that being a Meister company on average across the models increases the median survival time on the platform by 256 days.

As for the estimates of the control variables, they are mostly consistent with the results from the previous models. Employing more than ten employees decreases survival and companies with limited liability have lower survival spans than fully-liable companies. Finally, there is a significant positive effect of insurance on survival.

\section{Conclusion and policy implications}

Certifying professionals is an alternative to erecting market entry barriers in markets where information is incomplete. Empirical studies of professional voluntary certification schemes are scarce, although they are in theory an attractive means of reducing consumer search costs.

In the German crafts sector, voluntary certification and occupational licensing have co-existed since 2004. Using data from an online platform for crafts services on which craftsmen and customers interact, we have found that in trades that are subject to a voluntary scheme, the presence of a person with a Meister certificate - i.e. a person with an advanced training degree - improves service quality as perceived by the consumer. This result is confirmed in a variety of empirical specifications.

We argue that our findings show that the Meister certificate is a credible sign of quality for consumers which contribute to reducing search costs in the deregulated market segment. To this, it should be added that the Meister certificate is administered by the German Chamber of Crafts and Trades. This should also positively influence credibility as previous studies have shown that the source of information matters for the cost of acquiring it and that information provided by third parties (rather than directly by the producer) is generally more credible (see e.g. Ippolito and Mathios, 1990).

The topic of search costs in the German crafts sector is by no means exhausted yet. Due to the nature of our data, we are unable to analyze whether the Meister certificate influences consumer behavior. Therefore, this important question is left to future research. Furthermore, quality most likely varies within the group of Meister companies as well as within the group of non-Meister companies. This, we do not address. Its impact on consumer search costs

\footnotetext{
${ }^{12}$ The companies in the sample stay between 88 and 2801 days on the platform.
} 
could only be relieved through other mechanisms than the Meister certificate, such as reputation effects and online consumer rating portals.

Nonetheless, our analysis marks an important starting point in terms of understanding search costs in the German crafts market and the insights gained are relevant for the policy discussions surrounding the common European market. National entry regulations such as occupational licensing stand in the way of labor mobility and market competition. Our findings should ease popular concerns about eroding consumer protection under voluntary certification and weaken the position of those who prefer and even lobby for more activist government approaches. 
Table 9: Parametric estimation results

\begin{tabular}{|c|c|c|c|c|c|c|c|c|c|}
\hline & \multicolumn{3}{|c|}{ Gamma distribution } & \multicolumn{3}{|c|}{ Inverted Gaussian distribution } & \multicolumn{3}{|l|}{ No frailty } \\
\hline & Exponential & Weibull & Gompertz & Exponential & Weibull & Gompertz & Exponential & Weibull & Gompertz \\
\hline Meister & $273.66 * *$ & $270.10^{*}$ & 105.05 & $279.25^{* *}$ & $244.55^{*}$ & $171.55^{*}$ & $247.50 * *$ & $272.04 * *$ & $292.02 * *$ \\
\hline Employees 4-9 & 75.89 & 76.65 & 68.03 & 79.78 & 83.95 & 59.04 & 48.44 & 61.22 & 65.27 \\
\hline Employees 10-20 & $-1006.15^{* * *}$ & $-1000.10 * * *$ & $-481.70^{* *}$ & $-1016.30^{* * * *}$ & $-956.30^{* * *}$ & $-700.63 * * *$ & $-914.01 * * *$ & $-978.63 * * *$ & $-1048.30 * * *$ \\
\hline UG (limited liability) & $-917.78 * *$ & $-876.00 * *$ & -266.02 & $-940.84 * *$ & $-952.65 * * *$ & $-634.90 * *$ & $-956.34 * * *$ & $-1013.03 * * *$ & $-1089.08 * * *$ \\
\hline GbR (full liability) & -455.87 & $-463.55^{*}$ & -274.81 & $-462.27 *$ & $-427.05^{*}$ & $-324.53 *$ & $-370.13 *$ & $-408.67 *$ & -436.16 \\
\hline Other & -290.32 & -270.10 & -89.83 & -315.48 & -335.80 & -229.11 & -301.21 & -336.54 & -356.04 \\
\hline Liability insurance & $1022.94 * * *$ & $1058.50 * * *$ & 931.38 & $1017.08 * * *$ & $890.60 * * *$ & $786.07 * * *$ & $864.03 * * *$ & $891.39 * * *$ & $954.71 * * *$ \\
\hline Employing a trainee & $1524.89 * * *$ & $1540.30 * * *$ & $1032.95 * * *$ & 1557.60 & $1529.35^{* * *}$ & $1151.41 * * *$ & $1302.79 * * *$ & $1416.28 * * *$ & $1518.50 * * *$ \\
\hline Prob>chi^2 & 0.00 & 0.00 & 0.00 & 0.00 & 0.00 & 0.00 & 0.00 & 0.00 & 0.00 \\
\hline $\mathbf{N}$ & 3,483 & 3,483 & 3,483 & 3,483 & 3,483 & 3,483 & 3,483 & 3,483 & 3,483 \\
\hline
\end{tabular}




\section{Literature}

Akerlof, G. A. (1970), "The Market for "Lemons": Quality Uncertainty and the Market Mechanism”, in: The Quarterly Journal of Economics 84(3), 488-500.

Becker, G. (1964), "Human Capital- A Theoretical and Empirical Analysis, with Special Reference to Education", Seond Edition, National Bureau of Economic Research, Inc.

Boyd, D., Goldhaber, D., Lankford, H. and Wyekoff, J. (2007), "The Effect of Certification and Preparation on Teacher Quality", in: Future of Children, 17(1), Princeton University, 45-68.

Cabral, L. (2012), "Reputation on the Internet”, in: M. Peitz and J. Waldfogel (eds.) The Oxford Handbook of the Digital Economy, 343-354.

Caswell, J. and Anders, S. (2009), "The Economics of Market Information related to Standards and Certification in Fisheries", in: Roundtable on Eco-Labelling and Certification in the Fisheries Sector, background paper prepared for the OECD.

Chamberlain, G. (1985), "Heterogeneity, Omitted Variable Bias, and Duration Dependence", in: Longitudinal Analysis of Labour Market Data, pp. 3-38. Edited by Heckman and Singer, Cambridge University Press.

Cleves, M., Gould, W., Gutierrez, R. and Marchenko, Y. (2010), “An Introduction to Survival Analysis Using Stata", Third Edition, Stata Press, USA.

Croninger, R., Rice, J., Rathbun, A. and Nishio, M. (2007), "Teacher qualifications and early learning: Effects of certification, degree, and experience on first-grade student achievement", in: Economics of Education Review, 26(2007), 312-324.

Dellarocas, C. (2003), "The Digitization of Word of Mouth: Promise and Challenges of Online Feedback Mechanisms”, in: Management Science 49(10), 1407-1424.

Dranove, D. and Jin, G. (2010), "Quality Disclosure and Certification: Theory and Practice”, in: Journal of Economic Literature 48(4), 935-963.

Greene, W. (2008), “Econometric Analysis”, Sixth Edition, Prentice Hall.

Heckman, J.J. (1976), “The Common Structure of Statistical Models of Truncation, Sample Selection and Limited Dependent Variables and a Simple Estimator for Such Models", in: Annals of Economic Social Measurement 5(4), 59-74.

Ippolito, P. and Mathios, A. (1990), "Information, Advertising and Health Choices: A Study of the Cereal Market", in: American Economic Review 85(2), 91-95.

Jenkins, S. (2008), "Survival Analysis with Stata", Web site for Survival Analysis with Stata materials: https://www.iser.essex.ac.uk/resources/survival-analysis-with-stata

Kane, T., Rockoff, J. and Staiger, D. (2008), "What does certification tell us about teacher effectiveness? Evidence from New York City", in: Economics of Education Review 27(2008), 615-631.

Kleiner, M. (2000), “Occupational Licensing”, in: The Journal of Economic Perspectives 14(4), 189-202.

Koch, A. and Nielen, S. (2016), “Ökonomische Effekte der Liberalisierung der Handwerksordnung 2004”, in: Wiso Diskurs 05. Friedrich Ebert Stiftung. 
Leland, H. (1979), "Quarks, lemons and Licensing: A Theory of Minimum Quality Standards”, in: Journal of Political Economy, 87(6), 1328-1346.

Muris, C. (2016), "Estimation in the Fixed Effects Ordered Logit Model", in: Review of Economics and Statistics, doi: 10.1162/REST_a_00617.

Nelson, P. (1970), “Information and Consumer Behavior”, in: Journal of Political Economy 78(2), 311-329.

Prinja, S., Gupta, N. and Verma, R. (2010), "Censoring in Clinical Trials: Review of Survival Analysis Techniques", in: Indian J Community Med 35(2), 217-221.

Resnick, P., Zeckhauser, R., Swanson, J. and Lockwood, K. (2006), "The value of reputation on eBay: A controlled experiment”, in: Experimental Economics 9(2), 79-101.

Rostam-Afschar, D. (2015), "Entry regulation and entrepreneurship- A natural experiment in German craftsmanship", Free University Berlin and German Institute for Economc Research, DIW Berlin.

Rostam-Afschar, D. (2014), "Regulatory Effects of the Amendment to the HwO in 2004 in German craftsmanship", in: Empirical Economics 47, 1067-1101.

Runst, P., Thomä, J., Haverkamp, K. and Müller, K. (2016), A replication of 'Entry regulation and entrepreneurship: a natural experiment in German craftsmanship'. Ifh working paper series.

Salop, S. and Stiglitz, J. (1982), "The Theory of Sales: A Simple Model of Equilibrium Price Dispersion with Identical Agents", in: American Economic Review 72(5), 1121-1130.

Salop, S. and Stiglitz, J. (1977), "Bargains and Ripoffs: A Model of Monopolistically Competitive Price Dispersions", in: Review of Economic Studies 44(3), 493-510.

Schneider, S. (2008), "Applying the ISCED-97 to the German educational qualifications", in: Silke S. Schneider (Hrsg.): The International Standard Classification of Education (ISCED97). An Evaluation of Content and Criterion Validity for 15 European Countries. Mannheim: MZES, 76-102.

Smith, G., Venkatraman, and Dholakia, R. (199), "Diagnosing the search cost effect: Waiting time and the moderating impact of prior category knowledge", in: Journal of Economic Psychology 20(1999), 285-314.

Stigler, G. (1961), “The Economics of Information”, in: Journal of Political Economy 69(3), 213225.

Stiglitz, J. (2000), "The Contributions of the Economics of Information to Twentieth Century Economics", in: Quarterly Journal of Economics 115(4), 1441-1478.

Traublinger (2014); „Meisterbrief und Meistervoraussetzung: Basis eines starken, innovativen Handwerks“, in: Ifo Schnelldienst, 16/2014.

Varian, H (1980), “A Model of Sales”, in: American Economic Review 70(4), 651-659.

Wilde, L (1980), “The Economics of Consumer Information Acquisition”, in: Journal of Business 53(3), 143-158.

Wooldridge, J. (2002), "Econometric Analysis of Cross Section and Panel Data". First Edition, MIT Press. 
Chapter III: Does occupational licensing really impact incomes? - The German crafts case 


\begin{abstract}
The empirical literature on occupational licensing finds standard monopoly effects of entry regulations: Less competition and economic rents for professionals. I exploit the natural experimental design of a change in the German crafts regulation in 2004, which removed the traditional licensing requirement only for certain trades, and find no robust effects. I point out that the existing studies on the income effects of occupational licensing suffer from methodological weaknesses. Most studies rely on cross-section estimates that are likely to be biased due to unobserved heterogeneity whereas others do not rigorously define the population of interest. Based on my results, I suggest that demand-effects and market saturation have so far been inadequately discussed in the literature.
\end{abstract}

JEL Classification: I28, I39, J24, L51

Keywords: Labor markets, occupational licensing, monopoly rent, natural experiment, craftsmanship 


\section{Introduction}

Why do some occupations pay more than others? Occupational licensing (i.e. requiring minimum levels of human capital investment by professionals) is the strictest form of regulation to access professions that blocks market access for individuals without the necessary credentials. A large body of literature has found that the subsequent reduction in labor supply generates an income premium for market incumbents (see e.g. Friedman and Kuznets, 1954; and Kleiner and Krueger, 2010). This again is an incentive to lobby for perpetuating licensing requirements at ever-increasing standards (see Rottenberg, 1962).

National occupational licensing schemes have been steadily on the rise since the Second World War, in both Europe and the US (see Kleiner, 2006; and Kleiner and Kueger, 2010) replacing in part the decline in labor union membership. This development is at odds with European institutions' efforts to create a common market area with comparable regulatory frameworks to enable and foster the free movement of labor between countries (see COM, 2013) since costly investment in national specific qualifications precludes cross-country worker mobility.

In line with those efforts and in order to increase market competition by facilitating entry, the German regulator - contrary to the trend observed by Kleiner and colleagues - in 2004 liberalized the traditional occupation licensing scheme in the crafts sector. Since then, craftsmen in a number of crafts trades are no longer required to hold the traditional Meister title (an advanced vocational training certificate) to found a company to facilitate and foster entrepreneurship in craft trades.

Free market skepticism motivated by fear of earning erosion due to low-cost entrants may hinder the process of European integration. Both the EU enlargements of 2004-2013, the Commission's plans of integrating further eastern European states in the common market as well as the continuous extra-European immigration may spark such reservations. As a result, member states and national interest groups could be tempted to demand (and obtain) protective measures, which are thought to avoid a decrease of earnings in groups particularly affected by low-cost competition. An informed policy debate on how measures such as occupational licensing (and its suspension) actually affect incomes is therefore worth striving for.

In recent years, a number of studies have used the 2004 reform for this exact purpose. They have found significant negative income effects of removing occupational licensing in the 
crafts, which may fuel the popular concerns noted above (see Bol, 2014; Bol and Weeden, 2014; Damelang et al., 2017; and Lergetporer et al., 2016). I re-examine the effects of this deregulation and contrary to the existing literature, I find no convincing evidence of reduced incomes. In the explanation of these results, I go beyond the common focus on reduced price competition and thus the appearance of economic rent and propose alternative mechanisms whereby occupational licensing and incomes interact that also include the demand-side. I conclude that in light of my findings viewing occupational licensing as an "active labor market policy" to safeguard living standards is not only be harmful to the common market, but it may also not have the desired effect or - at best - it might affect incomes at random.

The remainder of this paper is organized as follows. Chapter two is a critical review of the related literature, before chapter three describes the data used for the empirical analysis. Chapter four details the methodology used, while chapter five summarizes the results. Finally, chapter six provides possible explanations for the findings, whereas chapter seven concludes.

\section{Related literature}

Human capital models in which individual rewards are a function of education and skills have been supplemented with contributions stressing the role of government regulation to explain income differences. Licensing schemes - which require minimum levels of human capital investment by professionals and as such constitute a market entry barrier - have received particular attention in the literature.

Several theoretical contributions (see e.g. Stigler, 1971; and Friedman and Kuznets, 1954) expect a positive link between occupational licensing and incomes, which empirical studies (see e.g. Kleiner and Kudrle, 2000; and Kleiner and Krueger, 2010) - mainly using US data have confirmed. Recently, several empirical studies concerning licensing and incomes have been conducted using the example of the German crafts sector, reaffirming this positive relationship (see Bol, 2014; Bol and Weeden, 2014; Damelang et al., 2017; and Lergetporer et al., 2016). However, the studies are subject to various methodological and interpretational issues.

Most empirical studies on the effects of occupational licensing use a cross-section study design. Some studies of the German crafts sector also use this methodology and find very strong and significant effects on incomes; for instance, Bol (2014) explores survey data for 2006 and finds that self-employed craftsmen subject to occupational licensing receive $13 \%$ 
higher income. However, in most cases, being subject to occupational licensing is not random, meaning that effect estimates will be biased unless all other factors influencing individual income are controlled for. It is difficult to perfectly control for individual human-level characteristics and differences in occupation-level productivity. The estimates of income differences between licensed und unlicensed professions are therefore likely to be biased due to this unobserved heterogeneity.

The German craft sector however actually presents researchers with a golden opportunity to improve on the cross-section design when examining the effects of occupational licensing, since the scheme was recently reformed in a way that resembles a natural experiment. The German craft sector is regulated by the so-called Trade and Crafts Code (Handwerksordnung) and comprises about 5 million professionals in 93 trades $^{13}$, which make up about $12 \%$ of the working population (Federal Statistical Office, 2016). From 1953 to 2004, all German craft trades were subject to a licensing scheme. Only craftsmen with a Meister title (internationally recognized as tertiary education) could found a company. Since 2004, market entry in certain trades ${ }^{14}$ has been open, although craftsmen in these trades can still choose to acquire the Meister title. In the remaining trades, the licensing requirement remains fully ${ }^{15}$ or partially ${ }^{16}$ intact. $^{17}$

Since the reform only affected certain craftsmen, it is in theory possible to assess the casual effect of removing occupational licensing using difference-in-differences estimation, which some studies have already done. This has the great advantage of eliminating the unobserved heterogeneity bias given certain key assumptions. With this approach, Damelang et al. (2017) find an average treatment effect of minus 13 euros per month in the deregulated trades. Lergetporer et al. (2016) find a significant negative reform effect on the incomes of employed craftsmen of $0.7 \%$ on average each year since the reform, with effect sizes only setting in 5 years after the deregulation. Using a second dataset and looking at total household incomes, they find stronger effect sizes (-8\% to $-12 \%)$, with employed craftsmen being more affected by the reform compared with self-employed craftsmen.

\footnotetext{
${ }^{13}$ The term "trade" pertains directly to the craft sector, whereas the term "occupation" is more general since a given occupation can contain both craft and non-crafts workers, as well as different craft trades. When referring to the German context, I will use the term "trade" to remain true to the German regulation. However, for insights on regulation, I will use the term "occupation" to align with the relevant literature.

${ }^{14}$ Examples of fully deregulated trades are tiles and mosaic layers, coppersmiths and tailors.

${ }^{15}$ Examples of fully regulated trades are roofers, gunsmiths and plumbers.

${ }^{16}$ Examples of partially regulated trades are optometrists, orthopedic and dental technicians.

${ }^{17}$ It was the political intention that both occupations considered hazardousness and/or providing a significant contribution vocational training in Germany should remain regulated. The minutes of the negotiations do however also provide evidence for interest group lobbying (see Bundestag, 2011; Bulla, 2012).
} 
While the authors of these papers conclude that workers in deregulated occupations have been affected negatively by the policy reform, it is worth highlighting the small effect sizes. Also, it is not clear that the observed income reduction from 2009 can actually be attributed to the policy change in 2004. Lergetporer et al. (2016) themselves note that they are planning future work which also includes more recent years in order to see beyond the financial crisis. It is also not clear why the authors use household income to investigate the effects of a reform that affects individual incomes. Again, Lergetporer et al. (2016) themselves point out that in this case, intra-household adjustments may bias results.

Furthermore, while the unbiasedness of the difference-in-difference estimator does not require controlling for every difference (apart from the treatment itself) in the treatment and comparison groups, it does require that in the absence of treatment, the unobserved differences between treatment and comparison groups are the same over time. Since it is not possible for an individual to be simultaneously treated and non-treated, the identifying assumption of the same trend in the absence of treatment cannot be tested. However, researchers can examine whether the assumption of a common trend appears justified in the pre-treatment period. This aspect is not investigated by Damelang et al. (2017), while Lergetporer et al (2016) conclude that the common trends assumption holds after some procedure of observation matching (by which most of the effect size disappears).

Additionally, the allocation of observations into regulated and deregulated craft trades is problematic. The considered datasets often do not contain explicit information about craft membership, which thus must be defined from the occupation variable. However, the line between craft and industry activity in the occupation classification, which does not reflect the legal definition of the crafts, is blurred. This opens up room for discretion. To illustrate this Runst et al. (2016, p. 4) conduct a thorough re-examination of the crafts classification in Rostam-Afschar (2014) and find that: "the demarcation chosen [...] is most probably too broad: While it certainly includes many of the occupations that German craftsmen would practice, it also very likely contains a large proportion of non-crafts individuals who are unaffected by the policy reform".

Finally, in the interpretation of the results, the existing literature fails to recognize that there may be other channels besides economic rents linking occupational licensing and incomes. Also, since the average qualification level of craftsmen may have been affected by the reform, any income reduction may also just be a result of lower productivity. 
In this study, I again exploit the natural experiment provided by the German craft sector to shed light on the link between occupational licensing and incomes using difference-indifferences estimation. I contribute to the existing literature by addressing the aforementioned problems of previous studies.

\section{Descriptive data analysis}

\subsection{Dataset}

I use the microcensus dataset for 2000-2010, which is a representative official sample survey of the German population. ${ }^{18}$ This dataset has many attractive features for economic researchers: one percent of the German population (approximately 800000 individuals) are sampled, a broad range of economic and socio-demographic variables are covered, the data collection is executed by statistical officials through personal interviews and a response is compulsory for most questions. The last two features contribute to a very low unit nonresponse rate of $3 \%$.

The usual problems with data collection for income studies still hold for the microcensus. Notably, the very top or the very bottom of the distribution has a smaller chance of being included in income surveys and well-off individuals have incentives to under-report their income (see Hoeller et al., 2012). Nevertheless, the personal character of the data collection should limit these biases in the case of the microcensus. Furthermore, the extremes of the income distribution are probably less relevant when studying the craft sector.

Furthermore, individual income in the microcensus is reported in 24 intervals and hence not as specific as could be wished. In order to achieve a metric scale for the variable, I use a method described by the Leibniz Institute for Social Sciences ${ }^{19}$ where I assign the mid-point of the respective income interval for each observation. For the unbounded first and last interval, I assign 1.5 times the interval's lower bound and 0.75 times the upper bound, respectively. The more incomes are normally distributed within the intervals, the more accurate that this transformation will be. Although this feature of the microcensus might prevent picking up small changes in individual incomes over time, it also prevents

\footnotetext{
${ }^{18}$ For detailed information about the microcensus, see e.g.: N. Schwarz (2001).

${ }^{19}$ In: GESIS (Hg.): Mikrodaten-Informationssystem MISSY. URL:

http://www.gesis.org/missy/files/documents/MZ/Auswertungsbeispiel_BerechnungDes\%C3\%84quivalenzeinko mmens.pdf (downloaded am 24.07.2017)
} 
overemphasizing effects of very little economic consequence (see my previous critique of Damelang, 2017).

If one is to assess the implications of a particular policy change in the crafts sector, it is paramount that especially the treatment group only comprises individuals within this sector. Like most other datasets, the microcensus does not contain a separate crafts variable, which is a potential pitfall for researchers unfamiliar with the specific legal definition of the German craft sector. Several occupations cover both craft and industry activities, hence solely relying on this variable, which all published studies on the effect of the deregulation on incomes to date do, is unlikely to capture the true population of interest. Runst et al. (forthcoming) show that by using solely the occupation variable to identify the population of interest will lead to including non-craftsmen as well, in particular in the treatment group.

I use the method proposed in Runst et al. (forthcoming) for identifying the crafts, which combines the occupation codes in the microcensus with data from the Federal Institute for Vocational Education and Training on the share of crafts apprentices within each occupational code. Only occupations where this share exceeds $60 \%$ are considered as crafts here, which is an effective procedure for deriving a clean definition for the microcensus data, which excludes individuals in the agricultural or industrial or service sectors of the economy, which are unaffected by changes in crafts legislation. ${ }^{20}$

I restrict my analysis to the self-employed, in line with most studies on the income effects of the reform when self-employment can be identified in the data. Before as well as after the reform, craftsmen could seek employment regardless of their professional degree in all trades. The traditional licensing requirement concerns only craftsmen founding a company. It has however been argued that employees may have been affected by the reform through intra-firm bargaining effects (see notably Damelang et al., 2017). In theory, it is even imaginable that through such mechanisms self-employed are left fully unaffected by removing occupational licensing. In order to make sure that all theoretical effects of the reform are accounted for, I estimate an alternative specification (not presented in the paper) where the population of interest also include all employees in the German crafts sector. The findings do not change; hence I conclude that restricting the analysis to the self-employed is appropriate.

\footnotetext{
${ }^{20}$ The classification scheme in the microcensus (KldB1992) merges about about seven activity profiles related to cleaning into one code (934). According to the crafts classification scheme recently developed by the Federal Employment Agency (BAA, 2014 ), only three of these seven occupations belong to the crafts sector. As in Runst et al. (forthcoming), I therefore do not include cleaners in the analysis.
} 
Also, I distinguish between men and women as well as between part- and full-time workers as labor market studies tend to focus on homogeneous groups with respect to labor market participation (see e.g. Becker and Blossfeld, 2017).

The dataset only contains information on total net income and therefore no information on labor income. This is unfortunate since the reform would have only affected labor income and using total income will likely understate the reduction in income after the reform as public transfers will partly compensate for the reduction. Another reason to regret the absence of an earnings variable is that unobserved factors influencing other income sources may bias the results if they affect craft trades differently. Therefore, I only include in the sample respondents who reported that labor earnings are the primary source of their net individual income. Furthermore, I exclude monthly net incomes below 300 Euros (which are likely only noise) from the full-time working sample.

Finally, the total sample comprises 30,691 observations, of which $17 \%$ work in a fully deregulated trade. According to official German craft statistics ("Handwerkszählung”), my sample make up $7 \%$ of the total German craft population where the share of workers in a deregulated trade amounts to $20 \%$. Table 1 provides a descriptive summary of the sample in this study. 
Table 1: Descriptive statistics of the variables by treatment and control group

\begin{tabular}{|c|c|c|c|c|}
\hline & \multicolumn{2}{|c|}{ Treatment group } & \multicolumn{2}{|c|}{ Control group } \\
\hline & mean & St.d. & mean & St.d. \\
\hline Individual net total income & 1858.93 & 1608.98 & 2112.85 & 1925.82 \\
\hline Age & 45 & 10 & 45 & 10 \\
\hline Female & 0.23 & 0.42 & 0.13 & 0.34 \\
\hline Migrant & 0.10 & 0.31 & 0.06 & 0.23 \\
\hline Hours worked & 47 & 14 & 51 & 14 \\
\hline Part-time & 0.10 & 0.30 & 0.04 & 0.19 \\
\hline Time-in-current-job & 12 & 10 & 12 & 10 \\
\hline Number of employees & 4 & 15 & 5 & 14 \\
\hline \multicolumn{5}{|l|}{ Last labor market status } \\
\hline Unemployed & 0.01 & 0.12 & 0.01 & 0.10 \\
\hline Employed & 0.71 & 0.46 & 0.71 & 0.46 \\
\hline Student & 0.00 & 0.06 & 0.00 & 0.04 \\
\hline Other & 0.01 & 0.09 & 0.01 & 0.07 \\
\hline \multicolumn{5}{|l|}{ Marital status } \\
\hline Single & 0.25 & 0.43 & 0.20 & 0.40 \\
\hline Married & 0.64 & 0.48 & 0.71 & 0.45 \\
\hline Widow(er) & 0.02 & 0.13 & 0.01 & 0.11 \\
\hline Divorced & 0.10 & 0.30 & 0.08 & 0.27 \\
\hline \multicolumn{5}{|l|}{ Number of children } \\
\hline None & 0.63 & 0.48 & 0.58 & 0.49 \\
\hline One child & 0.18 & 0.39 & 0.20 & 0.40 \\
\hline Two children & 0.15 & 0.36 & 0.17 & 0.38 \\
\hline Three+ children & 0.04 & 0.20 & 0.05 & 0.22 \\
\hline \multicolumn{5}{|l|}{ General education } \\
\hline Lower secondary school & 0.51 & 0.50 & 0.62 & 0.49 \\
\hline Intermediate secondary school & 0.25 & 0.44 & 0.26 & 0.44 \\
\hline University entrance qualification & 0.23 & 0.42 & 0.12 & 0.32 \\
\hline \multicolumn{5}{|l|}{ Vocational qualification } \\
\hline None & 0.03 & 0.17 & 0.02 & 0.13 \\
\hline Vocational training & 0.89 & 0.31 & 0.96 & 0.19 \\
\hline Advanced vocational training & 0.08 & 0.27 & 0.02 & 0.15 \\
\hline University & 0.00 & 0.03 & 0.00 & 0.02 \\
\hline $\mathbf{N}(\max -\min )$ & \multicolumn{2}{|c|}{$5819-5235$} & \multicolumn{2}{|c|}{$27079-25456$} \\
\hline
\end{tabular}

Source: Microcensus 2000-2010

\subsection{Incomes in the German crafts sector}

Over the period considered, the average craftsman in Germany received 2066 euros net per month. As figure 1 clearly shows, for all of the sub-population considered and across the entire time span considered, craftsmen in deregulated trades have on average lower incomes than those working in the still regulated trades. 
Furthermore, a visual interpretation of figure 1 may suggest that deregulated occupations have been more strongly affected by certain developments around the time of the 2004 reform than trades subject to occupational licensing for the full-time sample and the male sample. No such effect can be observed for the female- and part-time sample.

However, this provides no conclusive evidence on a possible reform effect for the sub-groups concerned, in particular since incomes among men and full-time workers were already on a downward-sloping trend as the reform took place in both deregulated- and still regulated trades. Furthermore, one would have expected the effects of such a reform to be long-lasting however incomes in the deregulated sector pick up after 2005 and follow the same up-ward sloping trend as income in the still-regulated sector.

Another important insight from figure 1 relates to the years before the reform (2000-2004). As previously underlined, the treatment and control groups must follow identical trends in absence of the policy intervention for the treatment effect to be identifiable, although it is unclear whether this is the case here. For the male- and full-time samples, while the general evolution pre-treatment appears similar, the rise in incomes at the onset of the 2000s appeared earlier in the regulated trades. For the female- and part-time sample, it seems even more questionable that the parallel trends assumption holds. The rest of the paper is dedicated to investigating these intuitions using regression analysis. 
Figure 1: Evolution of incomes of self-employed (male, female, full-time and part-time) in the treatment- and control group
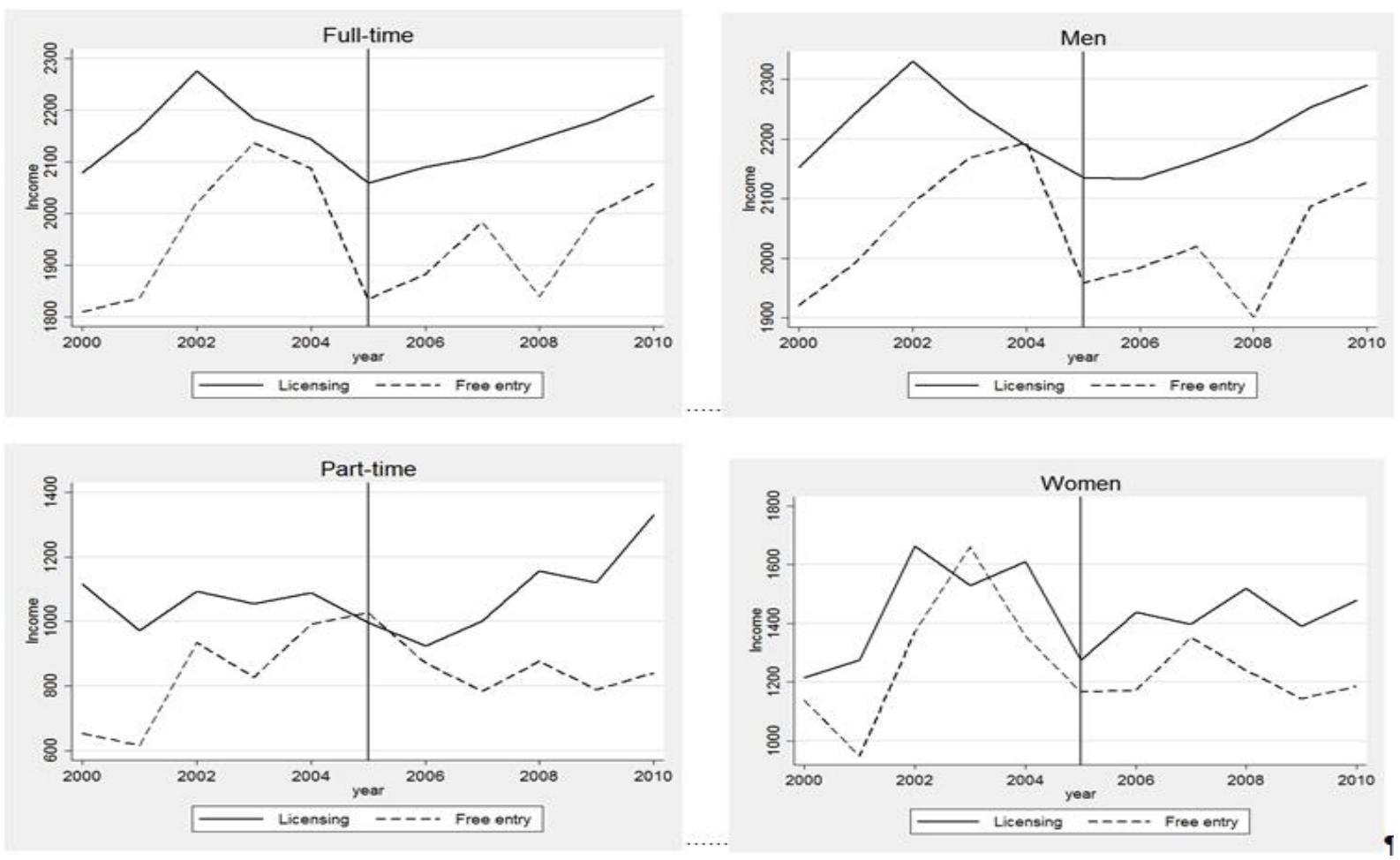

Source: Microcensus 2000-2010.

\section{Empirical approach}

\subsection{Estimation}

By using difference-in-differences (DID), researchers can benefit from the quasi-experimental research design of economic reforms that only affect certain groups. The average treatment effect of the treated is then calculated by comparing the average change over time in the outcome variable for the treatment group with the average change over time for the control group.

This methodological approach has been chosen in several existing studies on the effects of the reform in 2004 on market entry and exit effects and it is the approach that I favor to examine the income effects of the German crafts reform. I therefore estimate the following regression:

\section{[1] $Y_{i t}=\beta 1+\beta 2\left(\right.$ treat $\left._{i}\right)+\beta 3($ time $t)+\rho($ treat $i \cdot$ time $t)+\gamma(\mathbf{X}$ vector of controls $)+\epsilon i t$}

The dependent variable is the natural logarithm of monthly individual income. The treatment group is the fully deregulated B-trades. Trades that are still fully or partially subject to 
occupational licensing form the control group. The reform effect is the interaction term between the treatment groups and time after 2004. Years after 2004 are chosen since microcensus data is collected in April every year and it is unlikely that any income effects of the reform - which entered into force on January 1, 2004 - would have manifested during the first quarter of is year.

A concern in difference-in-differences analysis is that the policy may have been anticipated by the concerned individuals and as a consequence, they would have adjusted their behavior in the pre-treatment years. If the researcher is not aware of this, the estimation will not pick up existing treatment effects. Anticipation effects are very unlikely in the case of the German crafts deregulation. Very long there was great discussion and uncertainties regarding which crafts trades were to be deregulated. The governing coalition presented a reform proposal in in 2003 which it was criticized and rejected by the Federal Assembly, the upper house of the German parliament and as a result the final discussion in the mediation committee occurred on December 10 in 2003 after which many of the trades intended for deregulation would remain regulated or would be only partially deregulated (Runst, 2018). Still, to be on the safe side, I estimate an alternative specification (not presented in the paper) where 2004 is defined as the treatment year. The findings do not change, hence I deduce that choosing 2005 as the treatment year is not erroneous.

The vector of control variables includes general individual attributes, namely age, age squared, gender, having a migration background, state and city size. It also includes human capital measures of the highest obtained general education and vocational qualification. ${ }^{21} \mathrm{I}$ also control for a number of labor market attributes, namely working hours, the number of years spent in the current position, company size, occupation, previous labor market status as well as previous occupation. In addition, household characteristics are included, namely marital status and the number of children.

The Breusch-Pagan/Cook-Weisberg test for heteroscedasticity rejects the null-hypothesis of homoscedasticity. Therefore, I calculate robust standard errors allowing for intra-group correlation between different occupations.

Average effects may hide interesting developments for particular sub-populations. The construction sector may be a special case, in particular with respect to the impact of the

\footnotetext{
${ }^{21}$ The German terms regarding education/degree have been translated using a guide from the Federal Institute for Vocational Education and Training according to G. Batzel, 'Berufsbildungsbegriffe Deutsch-Englisch Terminologiesammlung für Berufsbildungsfachleute’ (2017) Berufsinstitut für Berufsbildung, Bonn.
} 
business cycle. Therefore, I run two separate regressions: one including only construction occupations and one excluding all construction occupations. I also look more closely at the floor-tiling occupation due to its non-negligible size (20\% of all construction craftsmen). Lastly, I look at a sample consisting only of Meister-companies, as means of looking at the effects of the reform on market incumbents. The existing literature on this reform that investigates heterogeneous effects mostly find significant income reductions only for male crafts (see Lergetporer et al., 2016). Hence, these regressions focus on the full-time male craftsmen sample.

I also estimate one specification with yearly interaction terms, which is able to pick up lagged effects as it is possible to consider a situation where reform effects take time to materialize. For instance, Lergetporer et al. (2016) find that significant income effects of the 2004 reform only appear with a five year lag.

The DID approach is only valid as long as unobserved factors are constant over time or change in a similar way for the treatment and control groups. Therefore, as is standard for DID analyses, I test the likelihood of common trends through a placebo test regression, where I exclude all observations in the post-reform period and simulate a treatment in the years preceding the reform.

I also estimate the baseline regression with an alternative control group. One obvious choice here is individuals outside the crafts sector. Additionally, I estimate the baseline DID regression with the fully deregulated trades as well as and partially deregulated trades as treatment groups and only the still fully regulated trades as the control group. Despite still being subject to occupational licensing, some trades were nevertheless affected by the reform in 2004 as subsequently experienced employees without a Meister title in these trades have been permitted to start a business. Moreover, a potential business owner without a sufficient degree was enabled to hire a company manager who possesses a Meister degree to start the business. 


\section{Results}

\subsection{Main findings}

Contrary to previous studies, I find no immediate indication of a negative effect on incomes for male craftsmen as a result of the deregulation in 2004. Surprisingly, a rather sizeable positive income effect for female craftsmen emerges, which is significant at the $10 \%$ level (see table 2, column 1 and 3 ). The adjusted $\mathrm{R}^{2}$ is only 0.22 , although a relatively low coefficient of determination is not uncommon in social sciences and does not exclude that the estimation yields relevant results (see Wooldridge, 2002).

Table 2: Main results

\begin{tabular}{|c|c|c|c|c|}
\hline & $\begin{array}{l}\text { (1) } \\
\text { Men full-time }\end{array}$ & $\begin{array}{l}\text { (2) } \\
\text { Men part-time }\end{array}$ & $\begin{array}{l}\text { (3) } \\
\text { Women full-time }\end{array}$ & $\begin{array}{l}\text { (4) } \\
\text { Women part-time }\end{array}$ \\
\hline Reformeffect & -0.0071 & 0.42 & $0.096^{*}$ & 0.032 \\
\hline Deregulated trade & $-0.13^{* * *}$ & -0.18 & $-0.41 * * *$ & -0.048 \\
\hline Post 2004 & $0.12 * * *$ & -0.18 & $0.15^{* * *}$ & 0.051 \\
\hline Age & $0.027 * * *$ & -0.015 & $0.039 * * *$ & -0.025 \\
\hline Age square & $-0.00032^{* * *}$ & 0.00019 & $-0.00050 * * *$ & 0.00027 \\
\hline Migrant & $-0.071 * * *$ & -0.019 & -0.070 & -0.0091 \\
\hline Time-in-current-job & $0.0069 * * *$ & $0.012 *$ & $0.0084 * * *$ & $0.0065^{* * *}$ \\
\hline Number of employees & $0.045^{* * *}$ & 0.028 & $0.0031 * *$ & 0.0020 \\
\hline \multicolumn{5}{|l|}{ Last labor market status } \\
\hline Unemployed & Comparison & Comparison & Comparison & Comparison \\
\hline Employed & $0.088^{* * *}$ & -0.16 & $0.18^{* * *}$ & 0.16 \\
\hline Student & $-0.18 * * *$ & -0.19 & -0.20 & $0.31 *$ \\
\hline Other & 0.0029 & -0.21 & 0.21 & $-0.20^{*}$ \\
\hline \multicolumn{5}{|l|}{ Marital status } \\
\hline Single & Comparison & Comparison & Comparison & Comparison \\
\hline Married & $0.12 * * *$ & -0.058 & -0.016 & $-0.23 * * *$ \\
\hline Widow(er) & 0.048 & 0.13 & $0.21 * * *$ & 0.24 \\
\hline Divorced & $0.038^{*}$ & -0.11 & $0.11 * * *$ & 0.045 \\
\hline \multicolumn{5}{|l|}{ Number of children } \\
\hline None & Comparison & Comparison & Comparison & Comparison \\
\hline One child & $0.048^{* * * *}$ & 0.078 & -0.026 & -0.043 \\
\hline Two children & $0.11^{* * * *}$ & $-0.26^{*}$ & -0.041 & 0.0034 \\
\hline Three+ children & $0.13^{* * *}$ & -0.17 & 0.13 & $0.14^{*}$ \\
\hline \multicolumn{5}{|l|}{ General education } \\
\hline Lower secondary school & Comparison & Comparison & Comparison & Comparison \\
\hline Intermediate secondary school & $0.063 * * *$ & $0.34 * * *$ & $0.058 * * *$ & 0.084 \\
\hline University entrance qualification & 0.0061 & 0.076 & 0.050 & $0.24 *$ \\
\hline \multicolumn{5}{|l|}{ Vocational qualification } \\
\hline None & Comparison & Comparison & Comparison & Comparison \\
\hline Vocational training & 0.010 & $0.27 * *$ & -0.064 & $0.36^{* * *}$ \\
\hline Advanced vocational training & 0.028 & $0.39 * *$ & -0.030 & $0.32 * * *$ \\
\hline \multirow[t]{2}{*}{ University } & $0.090^{* *}$ & 0.29 & 0.057 & 0.27 \\
\hline & 0.25 & 0.34 & 0.23 & 0.31 \\
\hline $\mathbf{N}$ & 17807 & 452 & 2506 & 547 \\
\hline
\end{tabular}

Source: Microcensus 2000-2010. 
When looking more specifically at different sub-groups of the male, full-time working crafts population, it becomes apparent that distinguishing between construction and nonconstruction occupations is important (see table 3, column 1 and 2). The deregulation appears to have reduced incomes by $6 \%$ in the construction crafts, a result which has high statistical significance. Symmetrically, when construction trades are excluded, there is no income impact of the deregulation for male full-time workers. Excluding the occupation 'floor tilers' changes nothing from the baseline results (see table 3, column 3).

Furthermore, it is interesting to note that in the sample consisting only of Meister-companies, the reform-effect is far from significant (see table 3, column 4). This implies that those companies in the previously regulated market overall have not seen their income drop as a result of the deregulation. This speaks against the predominant view of economic rents in the licensed occupations and favors the explanation that any drop in incomes is a result of changes in the average human capital of supply.

Table 3: Results by sub-group

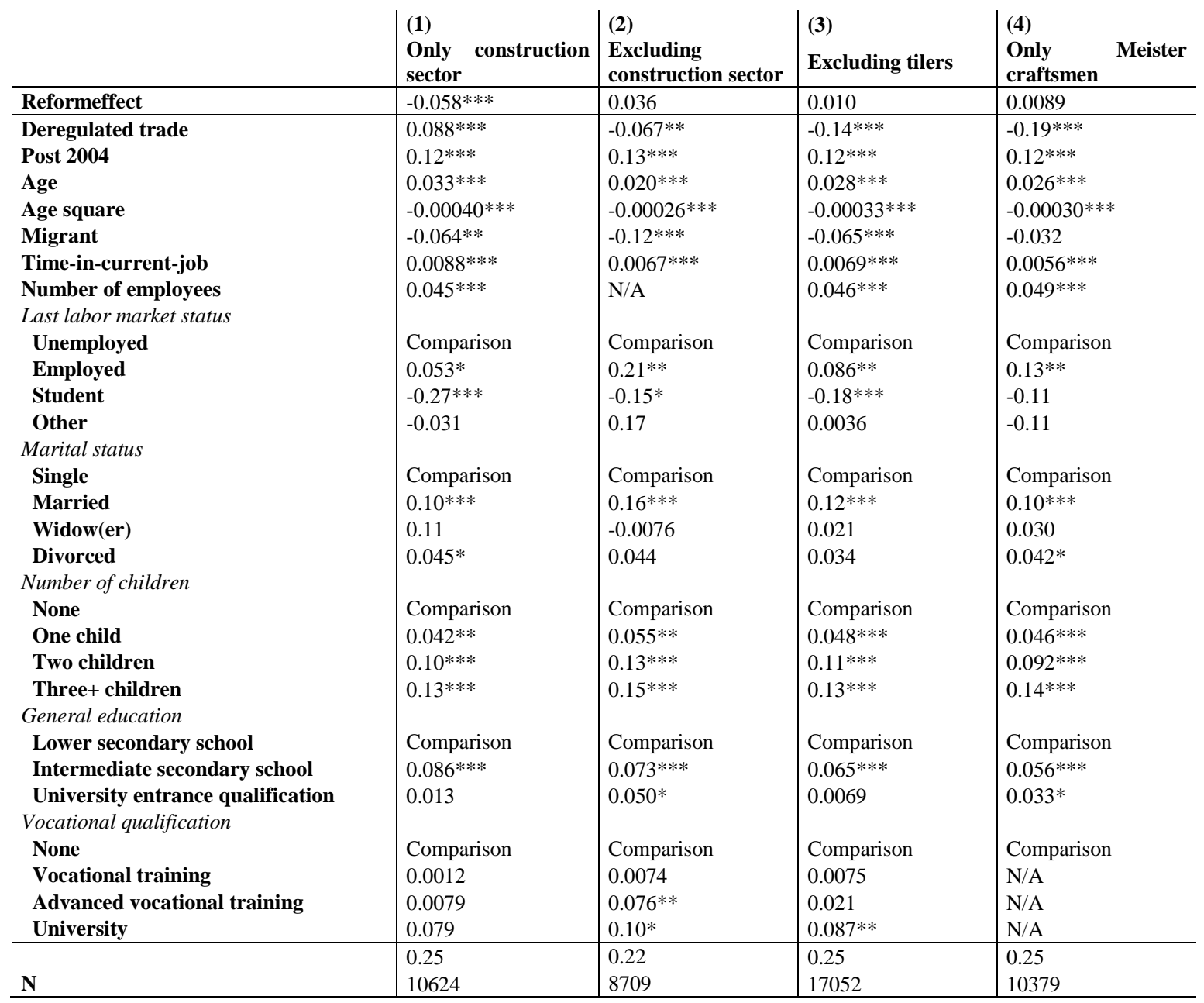

Source: Microcensus 2000-2010. 
Turning to the control variables, they mostly have the expected significance and sign. The estimate for working in one of the deregulated trades is mostly negative and highly significant and the estimate size almost identical to the existing literature $(-10 \%$ in column 1 , table 2 and $-12 \%$ in Bol, 2014).

This is the same finding that Bol (2014) uses to argue the existence of economic rents as a result of licensing in the German crafts sector. However, due to the likely presence of unobserved heterogeneity between trades, these estimates should certainly not be interpreted as a reform effect, nor is it a perfect causal effect of working in a deregulated trade. One important source of heterogeneity is human capital differences, which are inherently very difficult to measure. Beyond individual differences, another important source of heterogeneity is differences in productivity between firms, for which there are no variables in the microcensus dataset.

In full-time samples, age and migrant status both influence earnings, as could be expected from the economic literature. Incomes rise for each additional year of age, whereas migrants face an income penalty. Unsurprisingly, the number of hours worked significantly increases income, as does an additional year spent in the current position.

Household composition also matters for the income, although men and women are somewhat differently affected, not surprisingly. Full-time males as these craftsmen with children have significantly higher incomes than their childless counterparts. This result could in theory be explained by both the public subsidies given to families (as the income variable is net income and not labor income) as well as previous findings in the literature suggesting that high earners are more likely to find a mate (implying reverse causality). Given that this effect can only be found for males and not for the female sample and that for that same sample being married has a significant positive effect on incomes, the latter explanation seems most probable. However, the former could be behind the significant effect of having more than three children on the incomes of part-time working women.

The human capital variables have the expected sign and are sometimes significant. The effect of the intermediate secondary school degree (Realschule) is the most robust, which is also the most prevalent general education among individuals starting a vocational education in the German crafts. $^{22}$ The effect of the Meister-qualification itself in terms of qualification, the

\footnotetext{
${ }^{22}$ Among individuals being educated in the crafts in $2005,40 \%$ had a so-called 'Realschulabschluss', the intermediate school form in the German educational system, see Mueller (2017).
} 
effect of having completed advanced vocational education - which includes Meister craftsmen - is surprisingly not significant.

\subsection{Validity}

The specifications with alternative control groups corroborate the findings above. No significant income effects for male craftsmen are detected regardless of whether noncraftsmen form the control group or if the partially deregulated trades are switched from the control group to the treatment group (see table 4, coloumn 1 and 2). A significant positive income effect for women is found using both alternative control specifications (see table 4, column 3 and 4). The effect size when only fully deregulated trades form the control group is particularly strong. It should, however, be noted that the number of fully deregulated trades is very small, meaning that this specification should be interpreted with caution.

Table 4: Results using alternative control groups

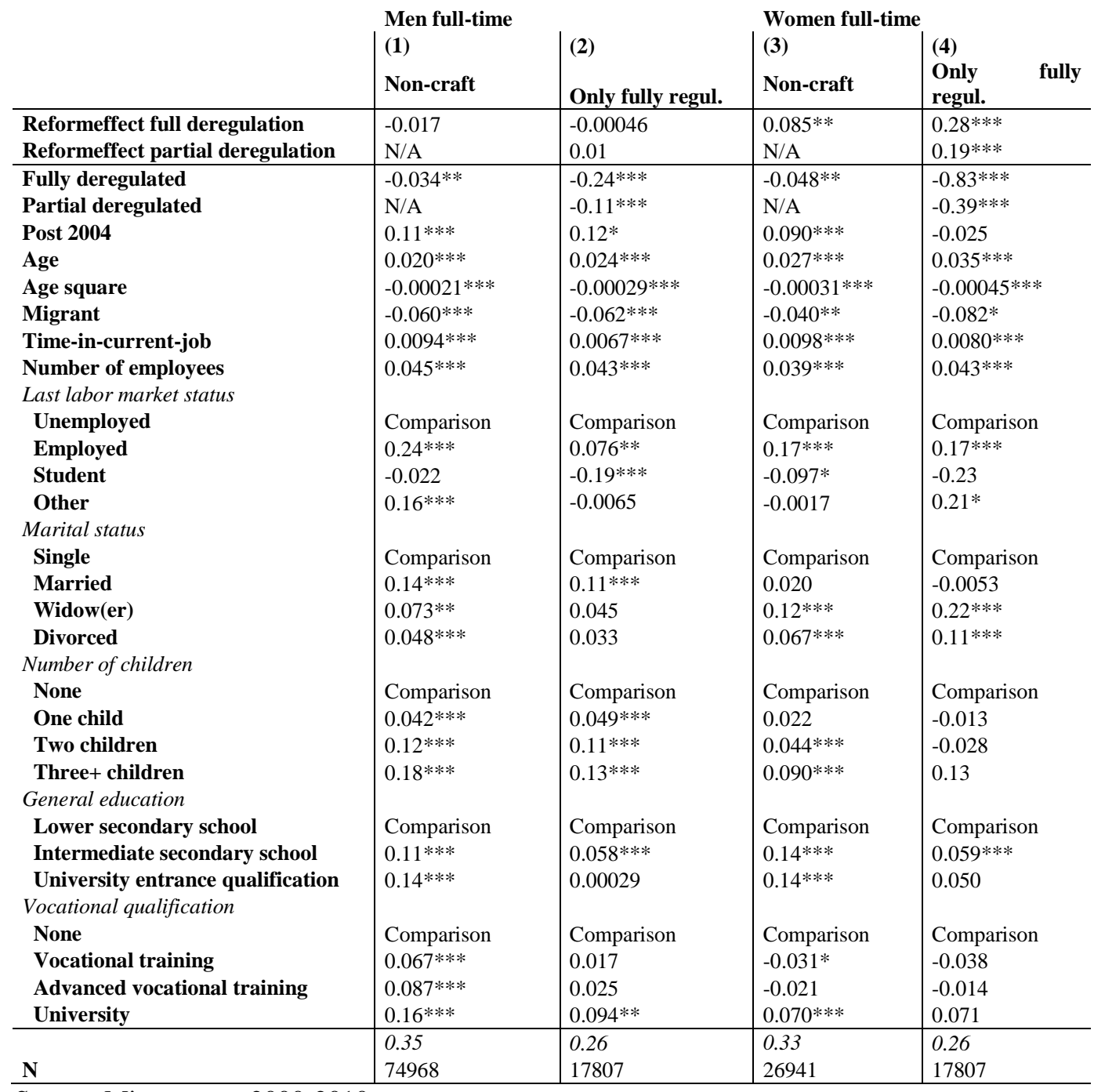

Source: Microcensus 2000-2010. 
Looking at lagged effects over a period of three years does not yield any new substance to the interpretation (see table 5). I would also caution against putting much weight on the interpretation of lagged effects as Lergetporer et al. (2016) do, since the more the analysis moves away from the reform implementation in time, the more one should be concerned that estimates may be picking up irrelevant developments affecting the outcome variable.

Table 5: Results with yearly interaction terms

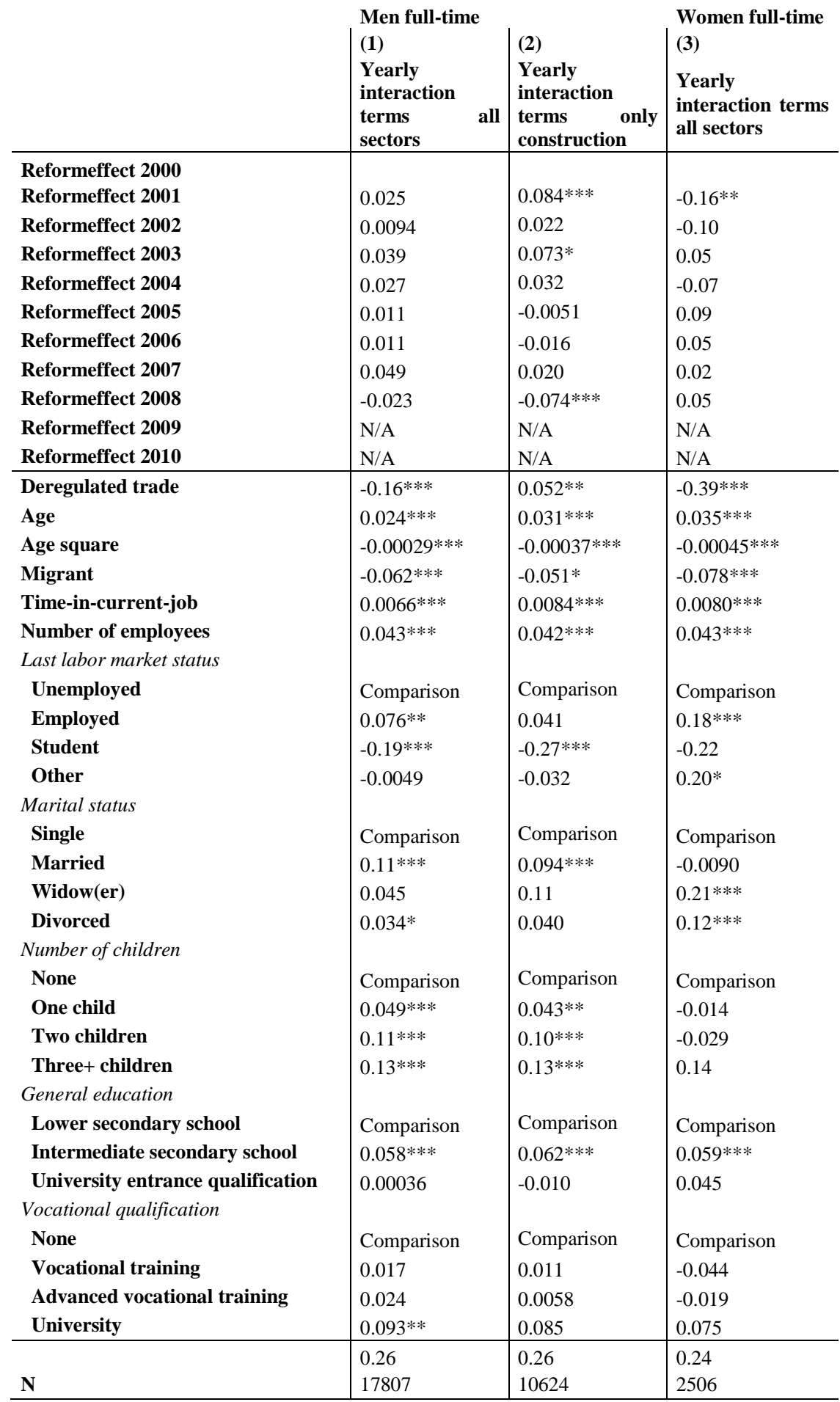

Source: Microcensus 2000-2010. 
The placebo test lends further credibility to the absence of income effects for male craftsmen. Simulated policy changes before 2004 all have insignificant effects on income (see column 1, table 6). The same procedure mostly holds for construction crafts trades, but fails in 2001, where a significant placebo-reform is found (see column 2, table 6). Hence, the significant negative income-effect found in the construction sector should be taken with a grain of salt. As for the female sample, the common trends assumption appears clearly to be violated since the placebo-reform is significant in the two years preceding the deregulation (see column 3 , table 6). This problem is consistent with concerns in Lergetporer et al. (2016) that differences between treatment and control groups may in some cases be too heterogeneous to identify a causal difference-in-difference estimator.

Table 6: Placebo-tests checking whether the common trends assumption holds

\begin{tabular}{|c|c|c|c|}
\hline & $\begin{array}{l}\text { Men full-time } \\
\text { (1) }\end{array}$ & (2) & $\begin{array}{l}\text { Woman full-time } \\
\text { (3) }\end{array}$ \\
\hline & $\begin{array}{l}\begin{array}{l}\text { Placebo-reform all } \\
\text { sectors }\end{array} \\
\end{array}$ & $\begin{array}{l}\text { Placebo-reform only } \\
\text { construction }\end{array}$ & $\begin{array}{l}\text { Placebo-reform } \\
\text { all sectors }\end{array}$ \\
\hline 2001 & 0.03 & $0.06 * *$ & -0.09 \\
\hline 2002 & 0.01 & 0.01 & 0.03 \\
\hline 2003 & 0.02 & 0.03 & $0.09^{* *}$ \\
\hline 2004 & 0.02 & 0.03 & $0.09 * *$ \\
\hline $\mathbf{N}$ & $\begin{array}{l}0.25 \\
9682\end{array}$ & $\begin{array}{l}0.24 \\
5621\end{array}$ & $\begin{array}{l}0.27 \\
1280\end{array}$ \\
\hline
\end{tabular}

Source: Microcensus 2000-2010.

Lergetporer et al. (2016) address this in one of their estimations using propensity score matching. In doing so, the negative effect on incomes as a result of the deregulation all but disappears. This speaks for the results obtained in this study, nevertheless optimizing the chances of casual interpretations remain an important field for future policy research also in the case of the German crafts sector.

\section{Discussion}

This study is one of the first to exploit a natural experiment to examine the income premiums resulting from occupational licensing. This study challenges the mainstream view that there is a significant income premium benefiting professionals in licensed occupations. I find no evidence that reforming the traditional licensing scheme in the German crafts sector negatively affected the incomes of male craftsmen overall. Certain groups may have been affected (men in the construction sector negatively and females positively), however in both 
cases, I find worrying signs that the common trends assumption may not be met, reflecting a potential problem that is for the moment left unaddressed.

Previous studies highlight the mechanism whereby market entry barriers lead to higher prices and hence increase producers' incomes. However, other mechanisms that counterweigh this may be at work, which can help explain my contradictory findings. First, it is possible that there are no - or very low - economic rents in licensed occupations to begin with. Several contributions in the literature have challenged the Cournot theorem, according to which a competitive equilibrium only occurs as the number of firms proceeds to infinity (see e.g. Fama and Laffer, 1972; Stiglitz, 1987 p. 1042; and Bresnahan and Riess, 1991). In the case of Germany, by the end of 2003 - just before the reform took place - there were roughly 75,000 firms operating in the 53 different trades that make up the deregulated market segment (see Mueller, 2006). Hence, competition may already have been (close to) sufficient to ensure prices close to marginal costs.

Moreover, the demand-side should also be considered. Quality may be lower in noncompetitive markets, which over time could have reduced consumers' willingness to pay for the service. The empirical literature on the link between occupational licensing and quality is inconclusive (see e.g. Carroll and Gaston, 1983; Shilling and Sirmans, 1988; and Angrist and Guryan, 2007). Higher prices under licensing could also have led consumers to other means of acquiring the service or simply resigning to an inadequate status quo and purchasing no service at all. In both cases, demand for crafts services would be lower under occupational licensing putting a downward pressure on the incomes of licensed professionals and free entry could have sparked new earning potentials.

A licensing requirement may also increase incomes simply due to increased human capital and/or as a result of signaling to consumers that the occupation provides services of a particular quality (see Weeden, 2002). In this case, licensing would indeed lead to higher incomes and, vice versa, deregulation would lead to lower incomes. However, these developments are then a result of changes in productivity of professionals and not economic rents. The results in this study lend some credibility to this thesis as the removal of occupational licensing in the German craft sector did not affect Meister-companies, i.e. incumbents in the market.

Also, other (and less restrictive) education policies and means to signal quality such as screening, reputation mechanisms or voluntary certification could achieve the same outcome 
as licensing. If consumers have the means to find the quality that they seek, market entrants that propose a lower price/quality bundle should not pose a threat to incumbents. In the German case, the Meister-certificate still exist in the deregulated segment and indeed consumers of crafts services perceive that Meister craftsmen in deregulated trades offer higher quality than their non-Meister counterparts (see Fredriksen et al., forthcoming).

\section{Conclusion}

The insights from this study are relevant for the current policy discussions of harmonizing national labor markets in Europe where proponents stress the importance of achieving a unified European labor market whereas opponents worry about the potential adverse effects of a race to the bottom in terms of government regulation. This study criticizes the methodology and interpretations in existing studies on the income effects of the German deregulation and generally the established findings in the literature on occupational licensing and incomes.

The standard explanation for why occupational licensing increases incomes of licensed professional is reduced competition, which allows them to charge higher prices. Two different stories may however be told depending on the degree of competition in the regulated market: If competition is a regulated market is nonetheless high, there is no room to charge higher prices. If competition is low, so might productivity and incentives to innovate be. If the quality of products suffers, the demand-side will put a stop on the scope to raise prices. In either of these two cases, licensing would not lead to higher incomes.

The main implication that can be derived from my results is that public regulation is likely to affect economic outcomes through a variety of channels where some are more present in the policy debate than others. On top of this, effects may well vary across population groups. For these reasons, regulatory interventions in markets should not be taken lightly, but enacted with care and continually evaluated as the consequences unfold.

\section{Literature}

Akerlof, G. A. (1970), "The Market for "Lemons": Quality Uncertainty and the Market Mechanism", in: The Quarterly Journal of Economics 84(3), 488-500.

Angrist, J. and Guryan, J. (2007), "Entry of men into the labour market in West Germany and their career mobility", Journal for Labour Market Research 50(1), 113-130. 
Becker, R. and Blossfeld, H-P. (2017), "Income from Independent Professional Practice", National Bureau of Economic Research, Inc.

Batzel, G. (2017), "Berufsbildungsbegriffe Deutsch-Englisch Terminologiesammlung für Berufsbildungsfachleute". Berufsinstitut für Berufsbildung, Bonn.

Bol, T. (2014), "Economic returns to occupational closure in the German skilled trades", in: Social Science Research 46(2014), 9-22.

Bol, T. and Weeden, K. (2014), "Occupational Closure and Wage Inequality in Germany and the United Kingdom”, in: European Sociological Review 19(2014), 1-16.

Bresnahan, T. and Reiss, P. (1991), "Entry and Competition in Concentrated Markets", in: Journal of Political Economy 99(5), 977-1009.

Bulla, Simon (2012) 'Ist das Berufszulassungsregime der Handwerksordnung noch verfassungsgemäß?' Gewerbearchiv, 12:470-476.

Bundestag [German Parliament] (2011) Protokolle des Vermittlungsausschusses des Deutschen Bundestages und des Bundesrates für die 13. bis 15. Wahlperiode (1994 bis 2005): DVD-Edition der ... mit Materialien zur Erschließung, C.H.Beck, ISBN: 9783406617997.

Carroll, S. and Gaston, R. (1983), "Occupational Licensing and the Quality of Service: An Overview”, in: Law and Human Behavior 7(2/3), 139-146.

COM (2013), 676 Communication from the Commission to the European Parliament, the council and the European Economic and Social Committee on Evaluating national regulations on access to professions. Brussels, 02.10.2013.

Damelang, A., Haupt, A. and Abraham, M. (2017), „Economic consequences of occupational deregulation: Natural experiment in the German crafts", in: Acta Sociologica, 1-16.

Fama, E.F. and Laffer, A.B. (1972), "The Number of Firms and Competition", in: The American Economic Review 62(4), 670-674.

Fredriksen, K., Runst, P. And Bizer, K. (2016), "Masterful Meisters? Quality Effects of the Deregulation of the German Crafts Sector". Ifh working paper series.

Friedman, M. (1962), “Capitalism and Freedom”, University of Chicago Press.

Friedman, M. and Kuznets, S. (1954), "Income from Independent Professional Practice", National Bureau of Economic Research, Inc.

Hoeller, P., Joumard, I., Pisu, M. and Bloch, D. (2012), "Less Income Inequality and More Growth- Are They Compatible? Part 1. Mapping Income Inequality across the OECD”, OECD Economics Department Working Papers, No. 924, OECD Publishing, Paris.

Kleiner, M. (2000), “Occupational Licensing”, in: The Journal of Economic Perspectives 14(4), 189-202.

Kleiner, M (2006), “Licensing Occupations: Ensuring Quality or Restricting Competition?" Kalamazoo, MI: W.E. Upjohn Institute for Employment Research.

Kleiner, M. and Kudrle, R. (2000), „Does Regulation Affect Economic Outcomes? The case of Dentistry", in: Journal of Law and Economics 43(2), 547-582. 
Kleiner, M. and Krueger, A. (2010), „The Prevalence and Effects of Occupational Licensing”, in: British Journal of Industrial Relations 48(4), 676-687.

Lergetporer, P., Ruhose, J. and Simon, L. (2016), „Labor Market Effects of Entry Barriers to Self-Employment: Evidence from Deregulating the German Crafts Sector", Ifo Center for the Economics of Education, Ifo Institute.

Mussa, M. and Rosen, S. (1978), "Monopoly and Product Quality", in: Journal of Economic Theory 18, 301-317.

Müller, K. (2017), "Die Stellung des Handwerks innerhalb der Gesamtwirtschaft", in: Göttinger Handwirtschaftliche Studien, Band 99.

Müller, K. (2006), “Erste Auswirkungen der Novellierung der Handwerksordnung von 2004”, in: Göttinger Handwirtschaftliche Studien, Band 74.

OECD (2015), „In It Together: Why Less Inequality Benefits All“, OECD Publishing.

Rostam-Afschar, D. (2015), "Entry regulation and entrepreneurship- A natural experiment in German craftsmanship", Free University Berlin and German Institute for Economic Research, DIW Berlin.

Rostam-Afschar, D. (2014), "Regulatory Effects of the Amendment to the HwO in 2004 in German craftsmanship", in: Empirical Economics 47, 1067-1101.

Rottenberg, S. (1962), „The Economics of Occupational Licensing“, in: Aspects of Labor Economics, Princeton University Press, 3-20.

Runst, P. (2018), "Does the Deregulation of Occupational Licensing affect the Labor Market Participation of Migrants in Germany?, in: European Journal of Law and Economics, 45(3), 555-589.

Runst, P., Thomä, J., Haverkamp, K. and Müller, K. (forthcoming), "A replication of 'Entry regulation and entrepreneurship: a natural experiment in German craftsmanship", in: Empirical Economics.

Schwarz, N. (2001), “The German Microcensus”, in: Schmollers Jahrbuch 12, 649-654.

Shilling, J. and Sirmans, C. (1988), "The Effects of Occupational Licensing on Complaints against Real Estate Agents", in: The Journal of Real Estate Research 3(2), 1-9.

Stigler, G. (1971), "The Theory of Economic Regulation", in: Bell Journal of Economics and Management 2(1), 3-21.

Stiglitz, J. (1987), "Competition and the Number of Firms in a Market: Are Duopolies More competitive than Atomistic Markets", in: Journal of Political Economy 95(5), 1041-1061.

Spence, A.M. (1975), "Monopoly, Quality and Regulation", in: The Bell Journal of Economics 6(2), 417-429.

Weeden, K.A. (2002), "Why do some occupations pay more than others", in: American Journal of Sociology 108(1), 55-101.

Weeden, K.A. and Grusky, D. (2014), "Inequality and market failure", in: American Behavioral Scientist 58(3), 473-491.

Wooldridge, J. (2002), "Econometric Analysis of Cross Section and Panel Data". First Edition, MIT Press. 


\section{Chapter IV: Are estimates of the "natural experiment" in the German crafts sector causal?}

(with Petrik Runst) 


\begin{abstract}
Difference-in-difference estimation is a popular tool to gauge the effects of economic policies. In recent years, many papers have applied this tool to the German deregulation of the crafts sector in 2004 to draw lessons regarding the economic effects of occupational licensing. However, a difference-in-difference estimator is only valid when the treatment and comparison units would have evolved similarly in absence of the reform, an assumption which is non-testable. This paper investigates whether the policy insights based on existing studies hold water when the synthetic control method is used whereby comparison units are selected in systematic ways in order to resemble treated units. Overall, this robustness-check confirms the findings using difference-in-differences estimation, yet it also yields some interesting nuances notably regarding market exits.
\end{abstract}

\title{
JEL Classification:
}

Keywords: Synthetic control, Selection on observables, Occupational licensing, Craftsmanship 


\section{Introduction}

The German crafts sector presents researchers with a golden opportunity to examine the effects of occupational licensing since the scheme was recently reformed in a way that resembles a natural experiment. Prior to 2004, all German craft occupations were subject to a licensing scheme through the so-called "Meisterpflicht", a requirement to hold a Meister-title (an advanced vocational certificate) in order to found a company. The reform abolished the licensing scheme for certain craft occupations whereas others remain subjected to the traditional licensing scheme.

In recent years there has therefore been a surge of studies using the German crafts case and the deregulation in 2004 in other to examine economic effects of occupational licensing by means of the conventional difference-in-differences estimator (e.g. Rostam-Afschar, 2014; Runst et al. forthcoming; Runst, 2018; Koch and Nielen, 2016; Lergetporer et al., 2016; Damelang et al., 2017; Fredriksen, 2018).

Difference-in-differences estimation is a popular methodology among economists in order to gauge the effects of policy interventions that affect only a sub-group of the total population. A survey of economic studies published in 6 economic journals from 1990 to 2000 identifies 92 papers using this methodology (see Bertrand et al., 2004). There is good reason for this as it can circumvent the problem of unobserved heterogeneity. By comparing the difference in the treated group and the control group before and after a given intervention, the difference-indifferences estimator neither requires a perfectly randomized experiment nor controlling for systematic differences between the two groups.

However, the difference-in-differences estimator is only a casual effect of a given policy intervention when, in absence of the treatment, both treatment and control group would have followed the same trends over time, commonly referred to as the parallel trends assumption. A major concern in the policy evaluation is therefore whether in practice, the parallel trends assumption is plausible (Ryan et al., 2015).

A critical investigation of the validity of difference-in-differences estimation in the studies of the German crafts reform in 2004 has however so far not gone beyond standard placebo-tests. Yet, the parallel assumption depends on the non-treatment outcome for the treatment group after an intervention, which by definition is not observable, and hence it is in fact nontestable. Thus, investigating alternative methods that avoid this assumption altogether are warranted (Krief et al., 2016). 
This study therefore re-examines the effects of the 2004 deregulation on market entry and exits, the share of migrants and incomes using the synthetic control method. Synthetic control estimation addresses the above-mentioned methodological concerns of conventional difference-in-differences estimation by carefully selecting comparison units in order to reduce bias. As such, this study contributes to the existing literature by investigating the robustness of results obtained.

The use of occupational licensing in the crafts sector is still part of the German policy debate und one of the leading parties (CDU) favors a reversal of the 2004 reform. Making sure that views on the deregulation are founded on solid scientific evidence is therefore important. Also, this paper contributes to a general debate on the reliability of difference-in-differences estimates. Given the frequent use of this methodology to advice policymakers on the effects of their actions, such research is warranted.

This paper is organized as follows: Part two acquaints the reader with the use of occupational licensing in the German crafts and existing studies on the deregulation that came into effect in 2004. Part three details the synthetic control method used as robustness-checks for current findings in the literature regarding the 2004 deregulation. Part four presents the results and part five concludes.

\section{The German crafts sector and the 2004-reform}

The German craft sector is regulated by the so-called Trade and Crafts Code (Handwerksordnung) and comprises about 5 million professionals in 93 trades $^{23}$, which make up about $12 \%$ of the working population.

The Meister-title plays an important role in the German crafts. It is the highest degree of vocational training and internationally recognized as tertiary education. In order to acquire it a professional must first undergo basic training (typically 3 years), which takes place both in a private company and in college, and become a so-called Geselle. Thereafter, additional training and exams involving occupation specific knowledge as well as knowledge about business management and pedagogy must be passed to acquire and associated exams in order to become a Meister, (see Mueller, 2014).

\footnotetext{
${ }^{23}$ The term "trade" pertains directly to the craft sector, whereas the term "occupation" is more general since a given occupation can contain both craft and non-crafts workers, as well as different craft trades. When referring to the German context, I will use the term "trade" to remain true to the German regulation. However, for insights on regulation, I will use the term "occupation" to align with the relevant literature.
} 
Between 1953 and 2004, having a Meister-title was mostly a prerequisite to found a company in the crafts. The so-called "Hartz Reforms" of 2004 removed (fully or partially) the licensing requirements for certain trades in the German crafts sector.

Recently, a number of studies have been published that evaluate the economic effects of this reform (see Rostam-Afschar, 2014; Runst et al., forthcoming; Lergetporer et al., 2016; Koch and Nielen, 2016; Damelang et al. 2017; Zwiener, 1997; and Fredriksen, 2018). In particular, the studies by Runst et al. (forthcoming), Runst (2018) and Fredriksen (2018) are interesting since they rely on a novel classification scheme to isolate the crafts in population-wide datasets, which is vital in order to identify the effects of the policy intervention.

To summarize, these three studies provide policy-makers with the following insights: Removing occupational licensing leads to market entry, especially of low-qualified craftsmen, as well as market exits (Runst et al., forthcoming). The proportion of self-employed migrants as well as migrants employee increases, the latter effect however only concerns untrained individuals (Runst, 2018). No significant income effects of removing occupational licensing could be detected (Fredriksen, 2017).

Contrary to other case studies on occupational licensing, the German crafts studies could all exploit the fact that the reform only affected some individuals and therefore apparently provides researchers with a "natural" control group. Hence, common to these studies is a reliance on difference-in-differences estimation to gauge the effects of the 2004 regulation.

However, in contrast to laboratory experiments, natural experiments rarely fulfill the random treatment condition. In the case of the German crafts deregulation, the original bill relied on objective criteria such as hazardousness and contribution to vocational training in the crafts. If a trade was deemed to be potentially hazardous to third parties it would remain fully regulated or would only be partially deregulated and likewise if it made significant contributions to vocational training in Germany (see Bundestag, 2003a; and Bundestag, 2003b). Furthermore, there is evidence for interest group lobbying during the parliamentary discussions (see Bundestag, 2011; Bulla, 2012). ${ }^{24}$ This speaks against random treatment assignment.

Yet, none of the existing studies on the German deregulation go beyond conventional difference-in-differences estimation. Possible identification problems are assessed based on

\footnotetext{
${ }^{24}$ One member of parliament made the following statement concerning a trade which was intended to be deregulated: "Surgical device mechanics [Chirurgiemechaniker] play an important role in my local election district. Many of them vote for SPD [Social Democratic Party]", (Bulla, 2012).
} 
outcome observations in the pre-treatment period, although what matters for casual interpretation is what might have occurred in post-reform period. Also, while the placebo-test is in most cases passed, Zwiener (2017) and Fredriksen (2018) find worrying indications of the opposite. A further cause for concern are the findings in Lergetporer et al. (2016), who attempt to correct for differences in the treatment and control group and as a result see their estimated reform effect on incomes greatly influenced.

This calls for a robustness-check of the established findings using data driven procedures to construct the best possible counterfactual, which is the aim of this paper. More specifically, insights from Runst et al. (forthcoming) on market entry and exit after the German reform as well as in Runst (2018) on migrant (self)-employment and Fredriksen (2018) on incomes, are proofed using the synthetic control method first introduced to the economic science in Abadie and Gardeazabal (2003) and Abadie et al. (2010).

Several papers have shown that this is a useful endeavor. In their pioneering work on the synthetic control method, Abadie et al. (2010) re-evaluate the effects of California's tobacco control program and find much stronger effects that reported in earlier studies relying on cross-section estimates. In their re-analysis of a pay-for-performance initiative in the British health sector, Kreif et al. (2016) also uses the synthetic control method and find, in contrast to previous studies using difference-in-differences estimation, that mortality was not reduced and in some case even increased. O'Neill et al. (2016) re-examines the best practice tariffs scheme also in the British health sector using both the synthetic control method, a lagged dependent variable approach and matching on past outcomes. Finally, Peri and Yasenov (2018) using again the synthetic control method to confirm existing findings that influx of Cuban immigrants into Miami in 1980 had no effect on local wages.

\section{Methodology}

\subsection{Data}

To conduct the empirical analysis German microcensus data is used. There are several reasons for choosing the microcensus. Firstly, many of the existing studies on the 2004-deregulation use the microcensus and since this analysis complements existing results in the literature, it is preferable to use similar data set-up in order to achieve a comparable a robustness analysis. 
Secondly, when attempting to make the treatment- and comparison groups as similar as possible, it is beneficial to have many potential covariates at disposal. The microcensus is a broad survey which covers personal information (gender, year of birth, family status, citizenship etc.), labor market information (labor market status, occupation), human capital accumulation (schooling, further qualifications), total net income, retirement provisions) and household characteristics (marital status, number of children etc.).

Finally, as always when making comparative policy analysis, it is important to have reliable and representative data. The German microcensus is a representative official sample survey of the German population. It covers $1 \%$ of the population and is conducted annually. The mandatory nature of the census survey guarantees a low rate of item-non-response for most questions.

If one is to assess the implications of a particular policy change in the crafts sector, it is paramount that the sample - and in particular the treatment groups - only comprise individuals within this sector. The microcensus does not contain direct information on whether a professional works in the crafts sector. However, craftsmen can be distinguished from noncraftsmen on the basis of the occupational classification code (KldB1992). Most existing studies on the German crafts deregulation do this by the "eye-balling method".

For the purpose of this paper, a more rigorous method first proposed in Runst et al. (forthcoming) for identifying the crafts is employed, which combines the occupation codes in the microcensus with data from the Federal Institute for Vocational Education and Training on the share of crafts apprentices within each occupational code. Only occupations where this share exceeds $60 \%$ are considered as crafts here, which excludes individuals in the agricultural or industrial or service sectors of the economy, which are unaffected by changes in crafts legislation.

Cleaners as an occupational group are also excluded from the sample as there are reasons to doubt that this occupation code in the dataset can be considered a craft trade. ${ }^{25}$ Furthermore, owing to its size (45\% of all individuals in deregulated trades in the microcensus dataset), wrongfully including the cleaner occupation would severely bias any general conclusions about the reform.

\footnotetext{
${ }^{25}$ As in: P. Runst, J. Thomä, K. Haverkamp and K. Müller, ,A replication of 'Entry regulation and entrepreneurship: a natural experiment in German craftsmanship‘ (forthcoming).
} 
The traditional occupational licensing scheme was only ever relevant for self-employed. Hence, the analysis is mostly restricted to this sub-group. However, in the case of migrants, effects on the self-employed and their employees are assessed separately as the literature seems to suggest that in this case, employees might be indirectly affected by regulations directed at employers.

Lastly, as this analysis pertains to labor market participation, individuals younger than 18 or older than 66, are excluded from the sample.

Runst et al. (forthcoming), Runst (2018) and Fredriksen (2018) use the microcensus dataset with these same adjustments pooled for the period 2000-2010. For the synthetic control estimations, it is however necessary to transform the data into a panel dataset. Hence individual observations are first aggregated into one observation for each of the 92 occupations. Furthermore, all the 52 deregulated trades are then aggregated into one treated unit as suggested in Abadie et al. (2010). Finally, since the length of the pre-treatment period is particularly important for synthetic control estimations, the period considered is extended back to 1995 , which yields 9 pre-treatment years. ${ }^{26}$

The final sample for the robustness-check presented in this analysis consists of ca. 1000-5000 observations (depending on the variable considered), one for each occupation at each point in time where 16 observations are in the treatment group. Table 1 provides a descriptive summary of the variables used for this study. The market exit and exit variables are constructed as described by Rostam-Afschar (2014), based on the non-mandatory question about the employment status in the previous year, by comparing the current employment status with the one in the previous year. This non-mandatory question was included before 2005 for $0.45 \%$ of the German population and for $1 \%$ of the German population in 2005 and 2009. The migrant variable is the likelihood of being a migrant. It is equal to one if an individual migrated to Germany at some point in their life and zero otherwise. The income of self-employed craftsmen is based on the answer to the question "how high was your personal net total income last month"?

\footnotetext{
${ }^{26}$ In the case of market entry and exit, it was not possible to include the year 1996 due to a lack of observations.
} 
Table 1: Outcome- and predictor means

\begin{tabular}{l|cc} 
& $\begin{array}{c}\text { Average of all } \\
\text { deregulated } \\
\text { occupations }\end{array}$ & $\begin{array}{c}\text { Average of all } \\
\text { control } \\
\text { occupations }\end{array}$ \\
\hline Dependent variables & & \\
Market entry & 0,02 & 0,04 \\
Market exit & 0,13 & 0,18 \\
Share of self-employed migrants & 0,10 & 0,08 \\
Share of all migrant employees & 0,14 & 0,09 \\
Share of untrained migrant & 0,21 & 0,17 \\
employees & 1282,45 & 1583,26 \\
Incomes & & \\
\hline Predictors & 41,94 & 40,83 \\
Age & 0,62 & 0,65 \\
Male & 37,28 & 37,77 \\
Hours worked & 0,61 & 0,59 \\
Being married & 0,41 & 0,41 \\
Having children & 0,68 & 0,49 \\
Lower secondary school & 0,22 & 0,22 \\
Intermediate secondary school & 0,10 & 0,30 \\
University entrance qualification & 0,10 & 0,08 \\
No professional qualification & 0,74 & 0,61 \\
Vocational training & 0,13 & 0,12 \\
Advanced vocational training & 0,03 & 0,19 \\
University entrance qualification & &
\end{tabular}

Source: Microcensus 1995-2010.

\subsection{The synthetic control framework}

The synthetic control method relaxes the difficult parallel trend assumption necessary for unbiased difference-in-differences estimates. The general principle behind the method is to weight the outcomes of the comparison units in order to construct a superior counterfactual for the treated unit, with the weights being chosen such that the synthetic control best reproduces the outcome variable of the treated unit in the pre-treatment period. The set of possible comparison units is commonly referred to as "donor pool".

The formal framework ${ }^{27}$ of synthetic control estimation can be summarized as follows: The method takes as starting point a balanced panel dataset with $t=1, \ldots, T$. Pre-intervention periods are noted $T_{0}$ and post-intervention periods are noted $T_{1}$. This means that a treatment

\footnotetext{
${ }^{27}$ The explanations and notations of the theoretical framework are identical to those in Abadie et al. (2010).
} 
unit is exposed to the treatment during periods $\mathrm{T}_{0+1}, \ldots, \mathrm{T}$ and not in the period $1, \ldots, \mathrm{T}_{0}$. The synthetic control is defined as a weighted average of the units in the donor pool. It is

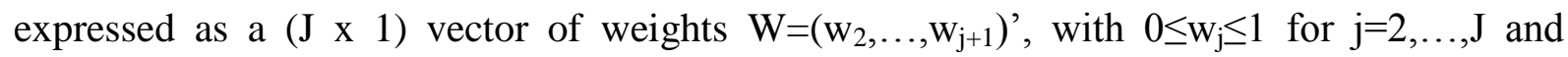
$\mathrm{w}_{2}+\ldots+\mathrm{w}_{\mathrm{j}}=1$.

The values of $\mathrm{W}$ are selected such that the characteristics of the treated unit best resemble the characteristics of the synthetic control. Consider $\mathrm{X}_{1}$, which is a ( $\left.\mathrm{k} \times 1\right)$ vector containing the pre-intervention characteristics of the treated unit and $\mathrm{X}_{0}$, which is an identical vector for the units in the donor pool. The differences between the treated- and comparison units are then given by $\mathrm{X}_{1}-\mathrm{X}_{0} \mathrm{~W}$. The synthetic control selected, $\mathrm{W}^{*}$, minimizes the size of this difference.

$$
\sum_{m=1}^{k} v_{m}\left(X_{1 m}-X_{0 m} W\right)^{2}
$$

$v_{m}$ is here the weight assigned to each control unit in the donor pool.

The synthetic control estimator is then given by the comparison between the outcome for the treated unit and the outcome for the synthetic control at that period. The outcome of unit $\mathrm{j}$ at time $t$ is noted $Y_{j t}$. $Y_{i}$ is a $\left(T_{1} \times 1\right)$ vector of the post-intervention values for the treated unit. $\mathrm{Y}_{0}$ is a $\left(\mathrm{T}_{1} \times \mathrm{J}\right)$ matrix containing the post-intervention values for the comparison units. The treatment effect is the given by:

$$
Y_{i t}-\sum_{j=2}^{J+1} w_{j}^{*} Y_{j t}
$$

The synthetic control approach has many advantages. Firstly, it allows the effects of unobserved confounders to vary over time, by reweighting the comparison group so that it has similar characteristics as the treatment group. Difference-in-differences estimation in contrast assumes that the effects of confounding variables are constant over time. Secondly, synthetic control estimation is very transparent. It is apparent whether the treated unit is sufficiently matched by the synthetic control and on this basis, the analyst can decide whether or not to go forth with the analysis. With conventional difference-in-differences estimation, estimate uncertainty is commonly reported by the standard error. The standard error however gives no information about the overlap (or lack thereof) between the treatment- and the control group, although these models have been shown to perform poorly when it is not the case (see e.g. Dehejia and Wahba, 1999/2002). 
The synthetic control method also has certain disadvantages. Notably, a systematic selection of comparison units can of course only be done on the basis of observed characteristics. Hence, idiosyncratic shocks affecting the outcome variable may make the synthetic control only appear similar and hence bias results. Abadie et al. (2010) show that this problem is alleviated when the pre-intervention period is long. In the case of the German crafts deregulation, our pre-treatment period is 9 years (from 1995 to 2004). Also, it will lead to a loss of observations as in our case individual observations need to be aggregated to the crafts trade level. However, this is a cost we are willing to pay as it has been said that "the main barrier to quantitative inference in observational studies is not the small-sample nature of the data, but rather the absence of an explicit mechanism that determines how comparison units are selected" (Abadie et al., 2015, p. 496).

\subsection{Identifying predictors of the outcome variable}

The synthetic control estimation is performed by the command synth in Stata. The program selects the comparison units, which are most similar to the treatment units based on observable characteristics that predict the outcome in the pre-treatment period. Researchers must however make the important choice of which predictors to include in the selection procedure. The principle aim is to include predictors that have a stable relationship with the outcome variable (McCelland and Gault, 2017). For the purpose of this analysis, several combinations of predictors are considered and the preferred predictor-specification will be the one with the lowest Root Mean Squared Percentage Error (RMSPE), which measures the pretreatment fit.

An obvious predictor is the lagged outcome variable because most structural economic outcomes, and certainly those considered in this analysis, do not vary much over time. Also, the lagged outcome variable will capture unobserved characteristics that influence the outcome variable. Athey and Imbens (2006) argue that including other variables rarely matter. Hence, in a first set of specifications, lags of the outcome variables are the only predictors in the synthetic control estimation. The recommendation from Ferman et al. (2016) to try different sets of lags and report the results from all of them is here followed. A first estimation includes the first, middle and last lag of the outcome variable as predictor as Gault (2017) recommend including only a few lags. A second estimation includes the last three lags of the treatment period as predictors, which is one of the recommendations in Kaul et al. (2016). A 
final estimation, inspired by the recommendations in both Kaul et al. (2016) ${ }^{28}$ and McClelland and Gault (2017) ${ }^{29}$, includes lags of the two years when the outcome variable is closest to its average in the pre-treatment period.

It has been pointed out that if other observables outcomes help predict the outcome, omitting them can bias the synthetic control outcome in the post-treatment period (Kaul et al, 2016). This is a serious critic as it relates to the credibility of the counterfactual, which is the aim of the synthetic control method to ensure. In order to address this possibility, a second set of specifications uses both the above-mentioned combinations of lags and other economic variables from the microcensus dataset that have predictive power for explaining the dependent variable (subsequently called "covariates") as predicators.

The findings in Heckman (1997) support a generous selection of covariates since the lowest bias values were obtained when the covariate vector included a rich set of variables relevant to modeling the probability of treatment. Also, Hahn and Shi (2017) recommend a relatively large number of predictors compared to the number of comparison units. Hence, the aim was to use all the significant covariates from the difference-in-differences in Runst et al. (forthcoming), Runst (2018) and Fredriksen (2018) as predictors. However, some control variables used in the original papers had to be dropped in order to be able to construct a synthetic control.

In the case of market entry and exit, the following covariates are included: Age, gender, a dummy for being married, a dummy for having children, education, professional qualification, a dummy for residing in former Eastern-Germany and the size of the resident city. In the case of migrants, the only covariates included are age, gender, marital status, the number of children and city size. Finally, in the case of incomes, the covariates included are age, age squared, gender, having a migration background, hours worked, highest obtained general education and vocational qualification, marital status and the number of children.

Concerns have been raised that including lagged outcomes as predictors may eliminate the effect of the other predictors (Kaul et al. 2016). A final predictor specification therefore only includes the covariates listed above as predictors without including lags of the outcomes. Due to the encompassing nature of the microcensus, the large number of variables at disposal should reduce the concern that important unobservable predictors are omitted.

\footnotetext{
${ }^{28}$ Kaul et al. suggest using an average of the outcome across all treatment years.

${ }^{29} \mathrm{McClelland}$ et al. recommend choosing a small number of lags that follow the outcome trend in the pretreatment period.
} 
For all these calculations, the donor-pool consists of both fully regulated trades and partially regulated trades. The reasons for this is that only considering the still fully regulated trades as comparison units would imply relying on very few craft observations in the control group. Also, previous studies typically find no reform effects in the partially deregulated trades. However, the sensitivity analysis addresses this issue further.

\subsection{Sensitivity analysis}

A general concern for comparative policy evaluation is that the intervention may have "spread" to units that were originally unaffected (Abadie et al., 2010). Avoiding such "tainted" units in the donor-pool is important for synthetic control estimation. The same procedure used in this paper to identify the crafts also sorts the German crafts trades into one of three groups: Fully deregulated in 2004, partially deregulated in 2004, or still regulated.

In the 52 occupations classified as fully deregulated trades, market entry is now free. These trades form the treatment group. The traditional licensing scheme remains unchanged for the 6 in the data categorized as still fully regulated. These are ideal comparison units; however there are few of them. The final 35 trades are classified as partially deregulated in 2004. For these trades, the law allows the crafts chambers to permit experienced employees without a Meister-degree to start a business. ${ }^{30}$ Prerequisites to be granted permission are that the employee have worked in the field for six years or more and have worked in a managerial position for four years or more or intend to hire a third-party company manager that meets the same criteria. ${ }^{31}$ An alternative specification removes these partially deregulated trades from the donor-pool.

Also, the policy literature has pointed out the danger of fake treatment effects (see e.g. Angrist and Krueger, 1999; Peri and Yasinov, 2018). This is particularly true with case studies that involve a small number of units of observation. Since the dataset had to be aggregated to the occupation-level in order to conduct the synthetic control method, a large observation loss occurred. Hence, as suggested in Abadie et al. (2003 and 2010), inference is analyzed through placebo tests. The placebo-tests are done using the specification including the best predictors and all occupations in the donor-pool. The basic idea is to apply the synthetic control method iteratively to every potential control in the donor pool (so-called "in-

\footnotetext{
${ }^{30} \mathrm{HwO} \S 7 \mathrm{~b}$, Altgesellenregel.

${ }^{31}$ Betriebsleiterregelung.
} 
space placebos"). Thus, it becomes apparent if any treatment effect detected is large relative to the distribution of placebo effects estimated for occupations not affected by the deregulation.

\section{Results}

\subsection{Results in the original studies using difference-in-differences}

Runst et al. (forthcoming) find that as expected the reform did cause a surge of new entrepreneurship in fully deregulated trades since it is found that market entry has increased between 1.0 to 1.8 percentage points. Contrary to Rostam-Afschar $(2014,2015)$, which this study replicates among other things by using a different classification scheme for the crafts, no effect was found on market entry with regards to trades where occupational licensing still exists in a milder form. Also in contrast to Rostam-Afschar $(2014,2015)$ who finds no effect of the deregulation on market exit, Runst et al. (forthcoming) find that the deregulation has increased exit probabilities in the fully deregulated trades by between 2.0 and 2.5 percentage points.

Runst (2018) concludes that the deregulation of occupational licensing has led to an increase in the proportion of self-employed migrants in the crafts sector. He finds an economically sizeable effect as the share of migrants has increased by 5 percentage points on average since the deregulation took place in the fully trades. Furthermore, it is found that the reform increased the likelihood of migrants to work as untrained employees in the crafts but not among highly trained employees or mid-range training levels. No significant effect of the reform was found on the share of migrants (whether self-employed or employed) in the trades that are still partially deregulated.

Fredriksen (2018) examine income effects only for self-employed and finds, contrary to Lergetporer et al. (2016) and Damelang et al. (2016), which also examine changes in incomes as a result of the deregulation, no convincing evidence of a significant negative effect. No overall significant negative effect on the incomes of all male craftsmen as a result of the deregulation in 2004. A closer look reveals that the deregulation appears to have reduced incomes by $6 \%$ in the construction crafts; however the standard placebo-test for parallel trends in the treatment and comparison group is not passed in this case. Surprisingly, a rather sizeable positive income effect for female craftsmen emerges, which is significant at the $10 \%$ 
level. However, also in this case, the placebo-test simulating an intervention in the pre-reform period is not passed.

These results using conventional difference-in-differences estimation is summarized in table 2 .

Table 2: Overview of original studies

\begin{tabular}{|l|l|l|}
\hline \multicolumn{1}{|c|}{ Study } & \multicolumn{1}{|c|}{ Outcome variable } & \multicolumn{1}{c|}{ Main findings } \\
\hline $\begin{array}{l}\text { Runst et al. } \\
\text { (forthcoming) }\end{array}$ & 1) Market entry & $\begin{array}{l}\text { 1) 1,0-1,8 percentage points higher entry in } \\
\text { fully deregulated trades }\end{array}$ \\
\cline { 2 - 3 } & 2) Market exit & $\begin{array}{l}\text { 2) 2-2,5 percentage points higher } \\
\text { likelihood of market exit }\end{array}$ \\
\hline \multirow{5}{*}{$\begin{array}{l}\text { Fredriksen } \\
(2017)\end{array}$} & $\begin{array}{l}\text { Net monthly income } \\
\text { for self-employed }\end{array}$ & $\begin{array}{l}\text { No overall significant effects on incomes } \\
\text { of self-employed. Possible negative effects } \\
\text { for males in the construction sector do not } \\
\text { pass placebo-tests }\end{array}$ \\
\hline \multirow{5}{*}{ Runst (2018) } & $\begin{array}{l}\text { 1) Self-employed } \\
\text { migrants }\end{array}$ & $\begin{array}{l}\text { 1) +5 percentage point higher share of } \\
\text { migrants }\end{array}$ \\
\cline { 2 - 3 } & $\begin{array}{l}\text { 2) Total migrant } \\
\text { employees }\end{array}$ & $\begin{array}{l}\text { 2) +4 percentage point higher share of } \\
\text { migrants }\end{array}$ \\
\cline { 2 - 3 } & $\begin{array}{l}\text { 3) Untrained vs. } \\
\text { trained migrant } \\
\text { employees }\end{array}$ & $\begin{array}{l}\text { 3) 5-7 percentage points increase in the } \\
\text { share of untrained migrants, no significant } \\
\text { effects for trained migrants }\end{array}$ \\
\hline
\end{tabular}

Source: Original studies.

\subsection{The synthetic control}

The novelty of this study is to apply the synthetic control method to the German crafts case instead of difference-in-differences estimations. Hence, we begin the presentation of our results by looking at the obtained pre-treatment fit of the synthetic control estimations (RMSPE), which is useful when comparing different specifications of the same model, as well as the composition of the synthetic controls in the case of the different outcome variables.

The combination of predictors that yields the best pre-treatment fit varies between the estimations. It is however noteworthy the absolute differences between the estimated RMSPE values is not large, meaning that the choice of the predictor specification should a priori not have a large impact on the validity (or lack thereof) of the synthetic control method. Furthermore, predictor specifications that include both a covariates and a combination of lagged outcomes consistently perform best. 
In the case of market entry, the preferred specification is combining the covariates from the microcensus dataset with the lagged outcome variables for the first, middle and last year of the pre-treatment period, see table 3 column 1. This particular specification yields a RMSPE of 0,00059 . In the case of market exit, using covariates and the two outcome lags most similar to the pre-treatment mean gives the best fit, see table 3, column 2. For incomes the best the best fit (lowest RMSPE) is achieved using covariates as well as the outcome variable in the first, middle and last year of the pre-treatment period (table 3, column 6), which is also the case when the reform-effect on self-employed migrants is assessed (table 3, column 3). For the analysis of migrant employees, the best fit is achieved when using only covariates or covariates in combination with the two lagged outcomes closest to the pre-treatment year (table 3, column 4). The synthetic control estimations of the reform-effect on untrained migrant employees is the only case where relying solely on lagged outcomes yields the best pre-treatment fit (table 3, column 5).

Table 3: Pre-treatment fit

\begin{tabular}{l|c|c|c|c|c|c} 
& $\begin{array}{l}\text { RMSPE } \\
\text { entry }\end{array}$ & $\begin{array}{l}\text { RMSPE } \\
\text { exit }\end{array}$ & $\begin{array}{l}\text { RMSPE } \\
\text { migrant } \\
\text { self- } \\
\text { emp } \\
\mathbf{( 1 )}\end{array}$ & $\begin{array}{l}\text { (2) } \\
\text { RMSPE } \\
\text { migrant } \\
\text { employees } \\
\mathbf{( 4 )}\end{array}$ & $\begin{array}{l}\text { RMSPE } \\
\text { migrants } \\
\text { untrained } \\
\mathbf{( 5 )}\end{array}$ & $\begin{array}{l}\text { RMSPE } \\
\text { incomes }\end{array}$ \\
\hline $\begin{array}{l}\text { Only outcome lags } \\
\text { LAG_A }\end{array}$ & 0,00266 & 0,03410 & 0,00928 & 0,01053 & 0,03816 & 0,02691 \\
$\begin{array}{l}\text { LAG_B } \\
\text { LAG_C }\end{array}$ & 0,00290 & 0,03332 & 0,00758 & 0,00813 & 0,02266 & 0,14187 \\
$\begin{array}{l}\text { Only individual } \\
\text { characteristics }\end{array}$ & 0,00296 & 0,03269 & 0,00816 & 0,00575 & 0,04175 & 0,04048 \\
$\begin{array}{l}\text { vars } \\
\text { Combination of the }\end{array}$ & 0,00279 & 0,09274 & 0,01146 & 0,00490 & 0,03921 & 0,02690 \\
above & & & & & & \\
vars+LAG_A & 0,00059 & 0,01858 & 0,00933 & 0,01004 & 0,05117 & 0,01781 \\
vars+LAG_B & 0,00177 & 0,01541 & 0,00999 & 0,00784 & 0,03206 & 0,02591 \\
vars+LAG_C & 0,00202 & 0,01208 & 0,01146 & 0,00490 & 0,03921 & 0,02456 \\
\hline
\end{tabular}

Note: For Lag_A, the first, middle and last lags of the outcome variable are predictors. For Lag_B, the three last lags of the treatment period are predictors. For Lag_C, the two lags closest to the pre-treatment mean are predictors. For Lag_x+vars, lag specification x and covariates are predictors.

Source: Microcensus 1995-2010.

The composition of the synthetic control varies between the various specifications and outcome variables, which the tables in annex 1 clearly illustrate. For market entry, non-crafts occupations make up more than $2 / 3$ of the synthetic control, whereas in the case of market 
exits, the synthetic control is solely comprised of craft occupations. In the case of incomes, non-crafts occupations is still one of the biggest contributors to the synthetic control, however in the preferred specification with covariates the main contributor are gunsmiths, an occupation with is part of the German crafts sector that was partially deregulated in 2004. In the case of migrants, very few occupations contribute more than $1 \%$ to the synthetic control. Among those that do, non-craft occupations again make up the most important part.

It is interesting to note that in some cases, the synthetic control is very diverse. We have chosen not to include occupations that contribute less than $1 \%$ to the synthetic control. A sum of weights far from 100 therefore indicates that many different occupations contribute in a minuscule way to the synthetic control. In most cases, these tiny contributions to the synthetic control aggregated actually makes up more than half of the synthetic control.

The fact that the synthetic controls predominantly consists of non-crafts occupations is also interesting. Whereas the three difference-in-differences studies highlighted in this paper do include non-craft occupations in the control group for sensitivity analysis, other published studies on the German crafts deregulation do not even consider non-crafts occupations in the analysis.

\subsection{Effects of removing occupational licensing in the German crafts}

The already well-established negative link between occupational licensing and market entry are negatively is confirmed also with the synthetic control method. However, it is worth noting that while the market entry reform-effect (gap between deregulated trades and their synthetic control) is positive, it still evolves very erratically in the post-reform period (figure 1). It is interesting to note a drop around 2008, which was not visible in the original study using difference-in-differences that seems to indicate that market entry was negatively affected by the financial crisis 
Figure 1: Gap in market entry between deregulated trades and synthetic control

\section{A: Only lags as predictors}

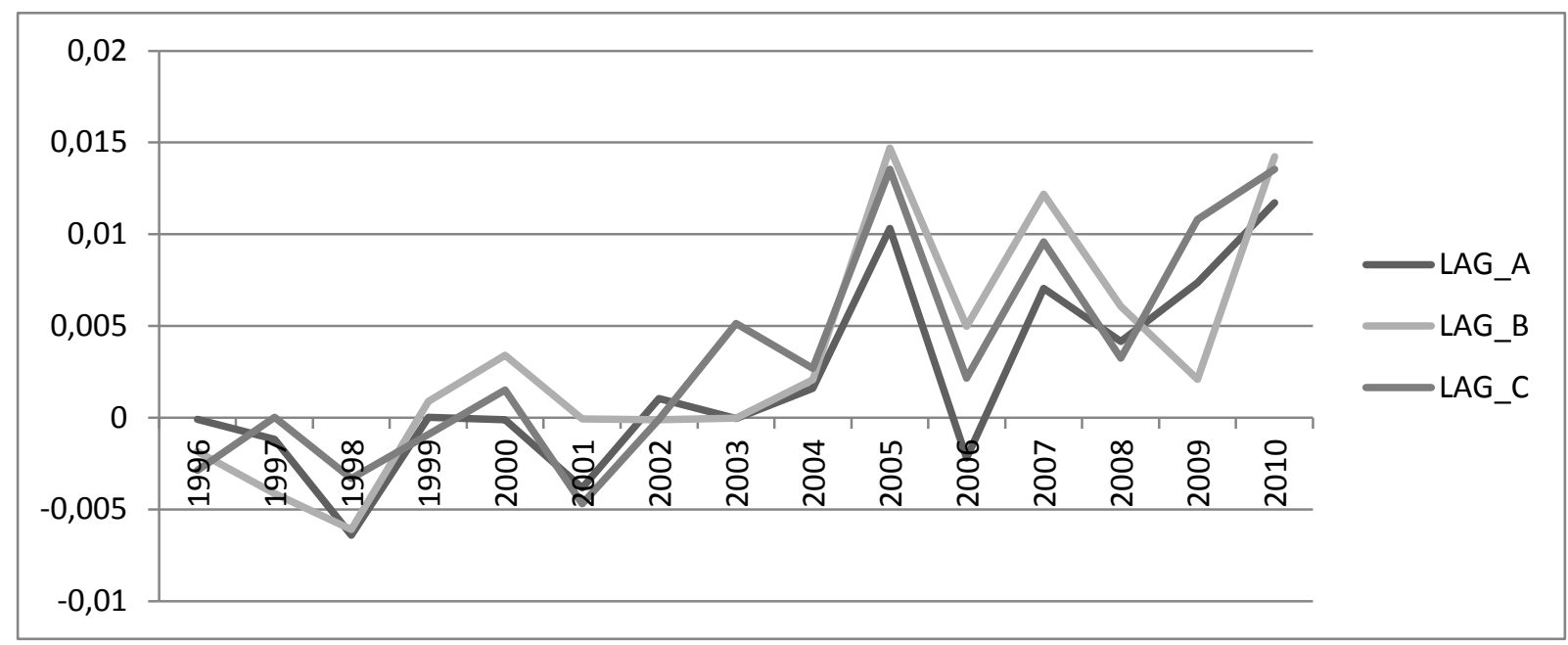

B: Combination of lags and covariates as predictors

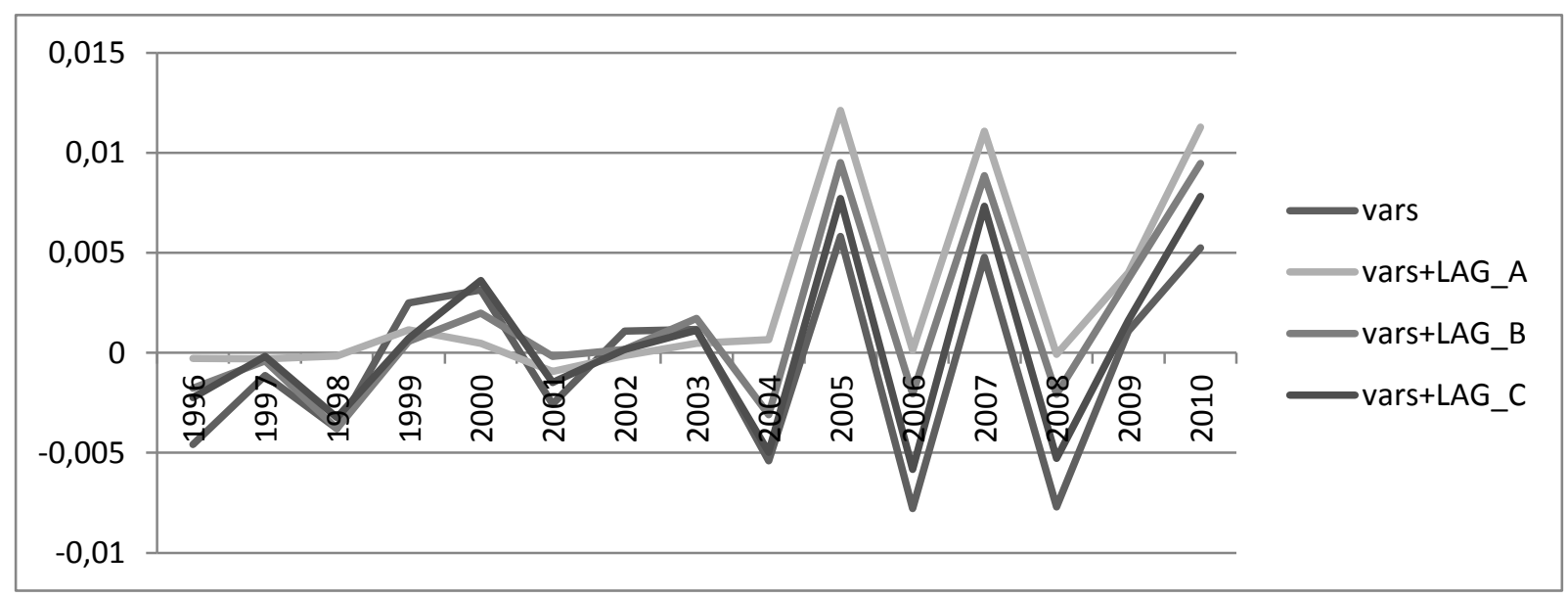

Note: For Lag_A, the first, middle and last lags of the outcome variable are predictors. For Lag_B, the three last lags of the treatment period are predictors. For Lag_C, the two lags closest to the pre-treatment mean are predictors. For Lag_x+vars, lag specification $\mathrm{x}$ and covariates are predictors.

Source: Microcensus 1996-2010.

It has been investigated whether the above-mentioned effect on market entry only concerns entrants from outside of German that have not had the same access to the German qualification system. In line with the findings in Runst et al. (forthcoming) and RostamAfschar (2014) we however also find that market entry has increased among self-employed craftsmen of German origin (see figure 2). 
Figure 2: Gap in market entry between deregulated trades and synthetic control- Only German craftsmen

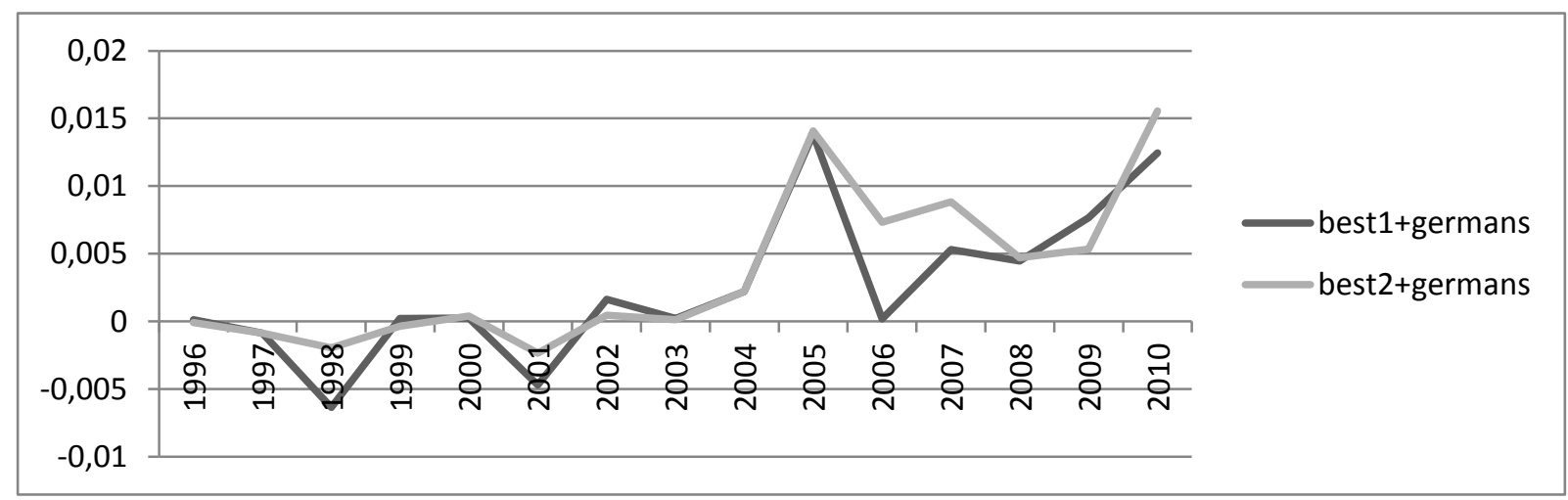

Note: Best1 refers to the specification with only lagged outcome variables as predictors that achieved the lowest RMSPE. Best2 refers to the specification with lagged outcome variables and covariates that achieved the lowest RMSPE:

Source: Microcensus 1996-2010.

On the more controversial issue of market exit, we are unable to confirm the positive effect reported in Runst et al. (forthcoming), see figure 3. The synthetic control estimations appear rather to confirm the findings in Rostam-Afschar (2014) who could not detect any exit effects.

Figure 3: Gap in market exit between deregulated trades and synthetic control

A: Only lags as predictors

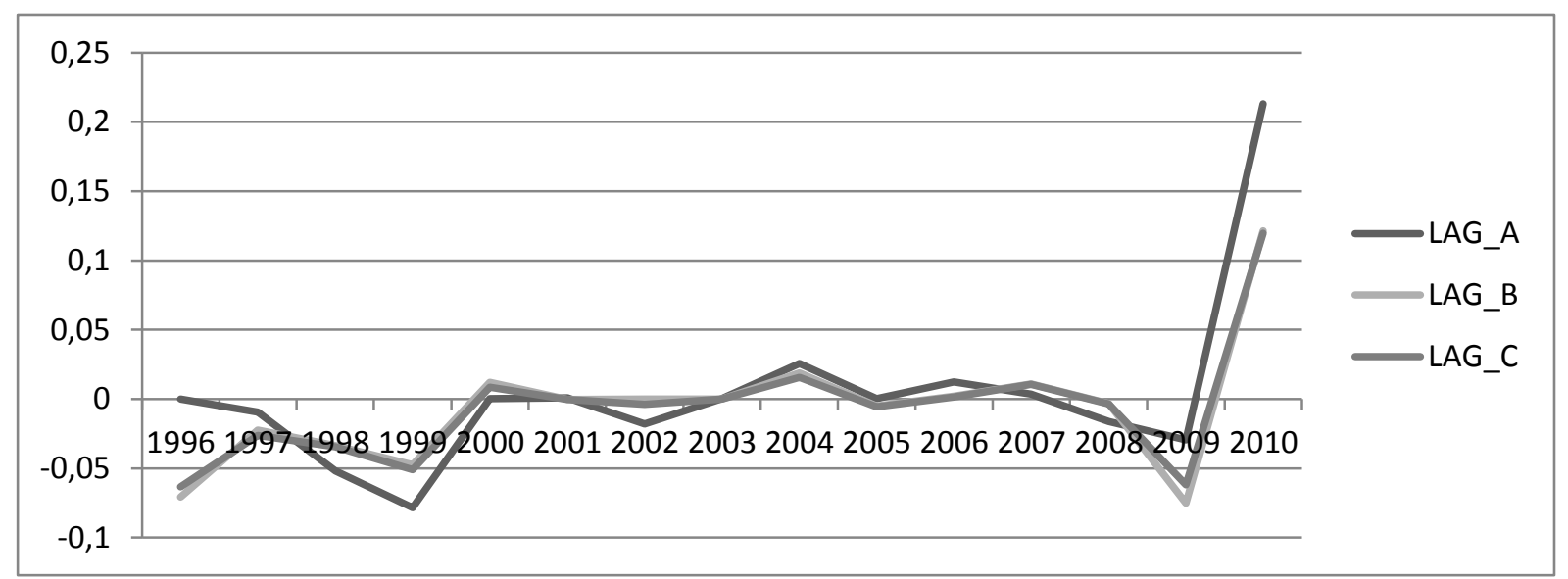


B: Both lags and covariates as predictors

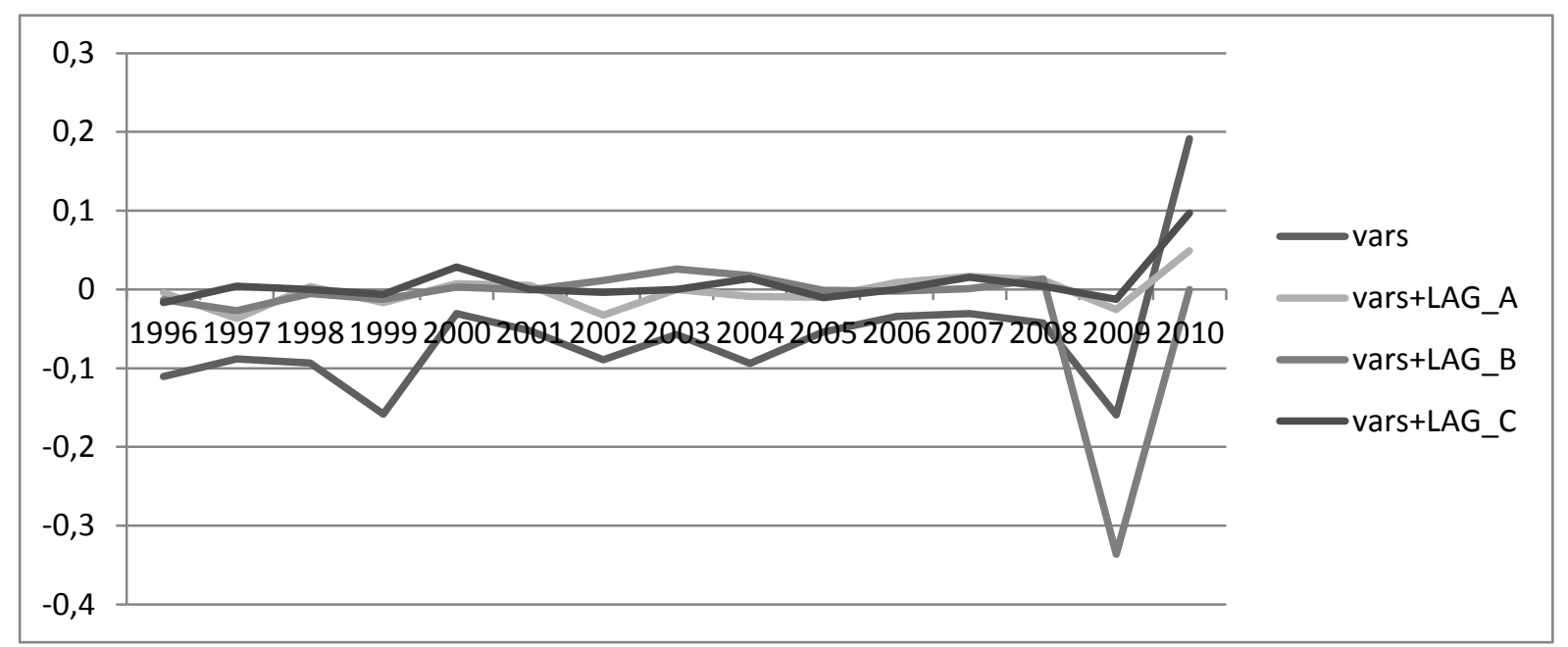

Note: For Lag_A, the first, middle and last lags of the outcome variable are predictors. For Lag_B, the three last lags of the treatment period are predictors. For Lag_C, the two lags closest to the pre-treatment mean are predictors. For Lag_x+vars, lag specification $\mathrm{x}$ and covariates are predictors.

Source: Microcensus 1996-2010.

The share of self-employed migrants has more or less continuously increased since 2004 (figure 4), which is not surprising given that the traditional licensing requirement only concerned founding a company. Hence, this is the direct effect of the deregulation in 2004. However, the effect is almost as strong for migrant employees, which confirms the existence of an indirect effect of the regulation coming from employment practices (figure 5). Contrary to the findings in the original paper, an effect on untrained migrants cannot be detected (results not presented). However, this is likely due to the low number of observations in the synthetic control estimations when the sample is thus reduced. 
Figure 4: Gap in the share of self-employed migrants between deregulated trades and synthetic control

\section{A: Only lags as predictors}

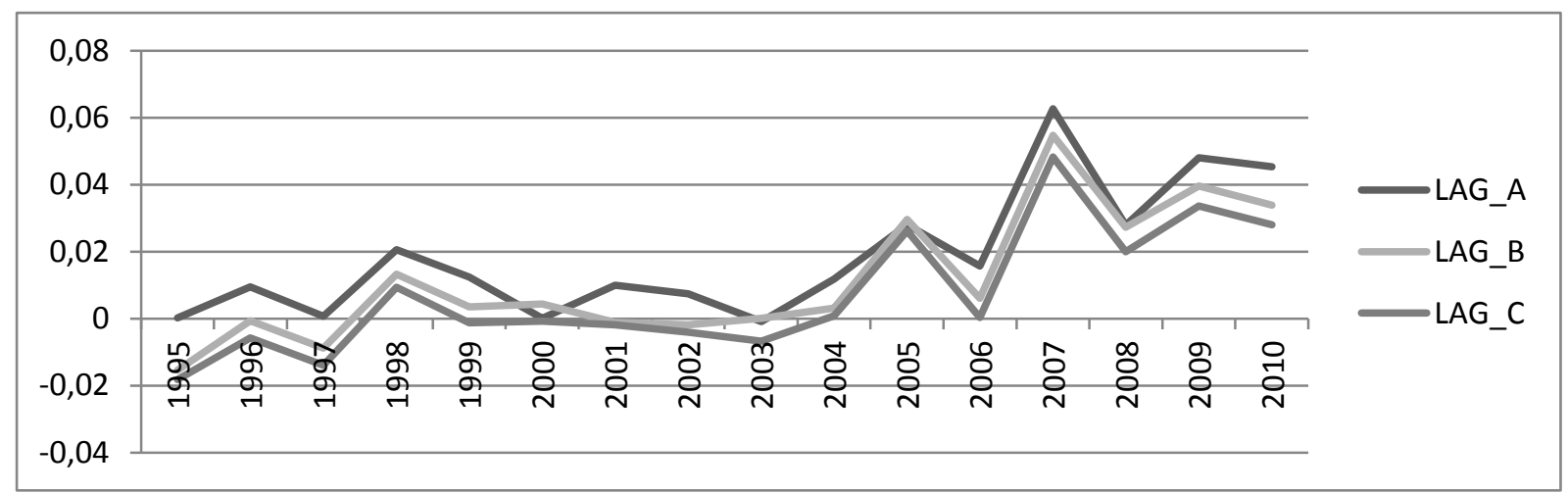

B: Combination of lags and covariates as predictors

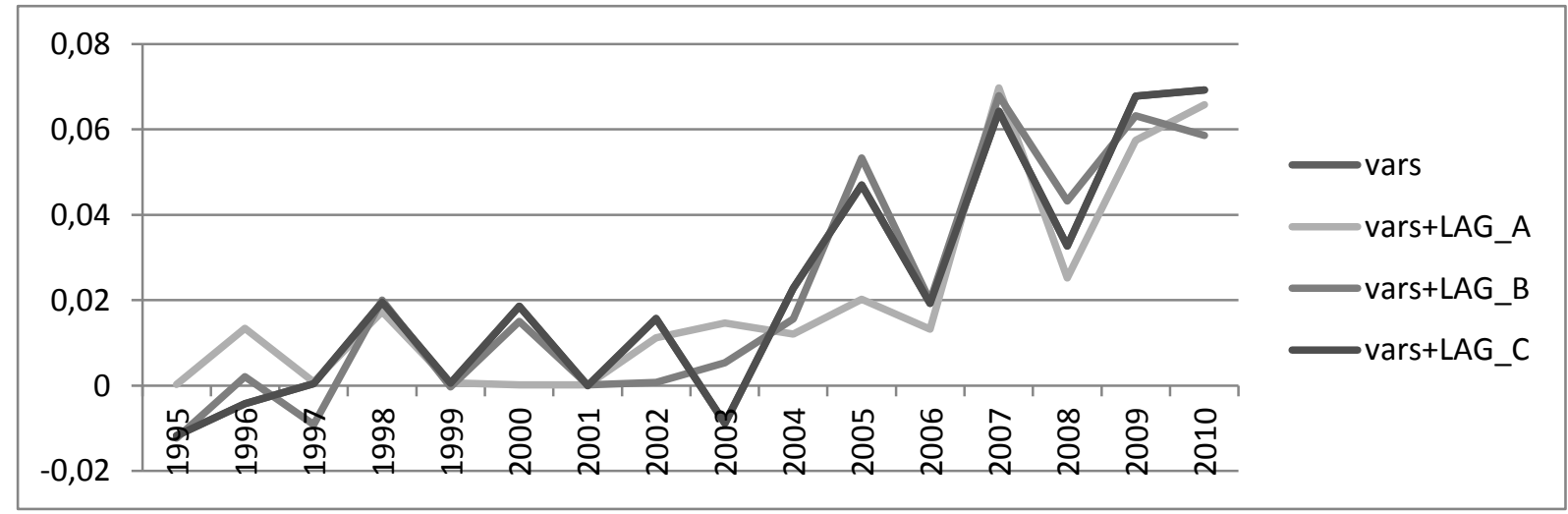

Note: For Lag_A, the first, middle and last lags of the outcome variable are predictors. For Lag_B, the three last lags of the treatment period are predictors. For Lag_C, the two lags closest to the pre-treatment mean are predictors. For Lag_x+vars, lag specification $\mathrm{x}$ and covariates are predictors.

Source: Microcensus 1995-2010. 
Figure 5: Gap in the share of all migrant employees between deregulated trades and synthetic control

\section{A: Only lags as predictors}

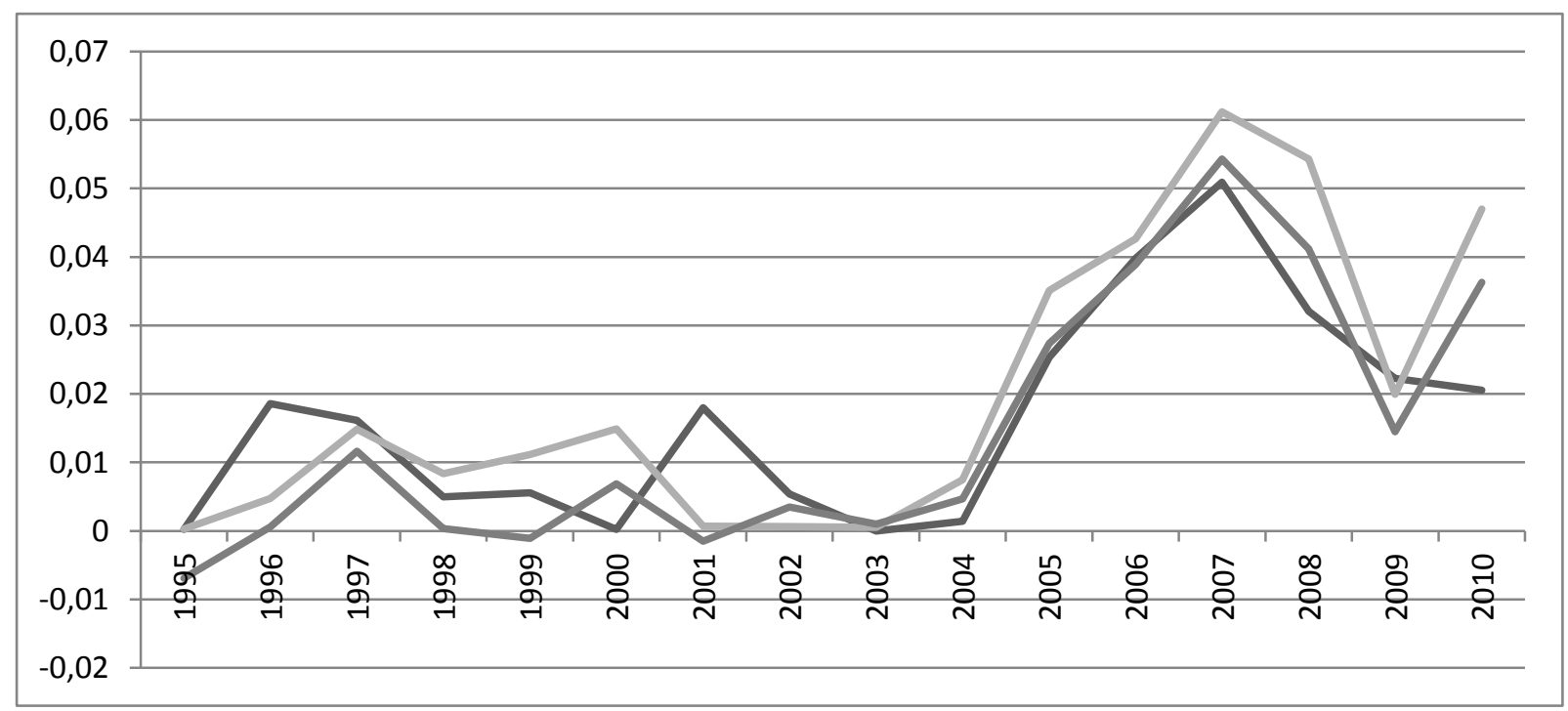

B Combination of lags and covariates as predictors

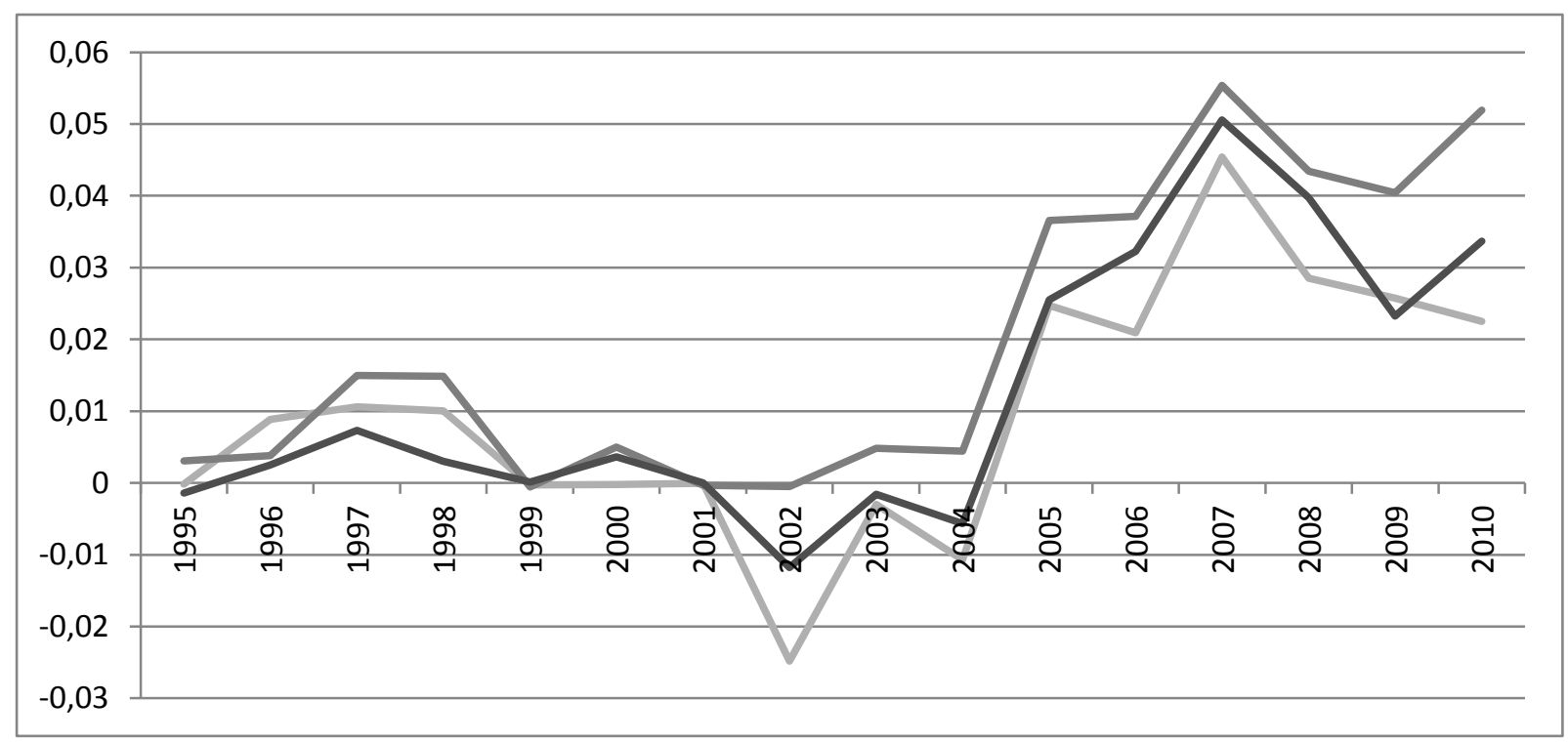

Note: For Lag_A, the first, middle and last lags of the outcome variable are predictors. For Lag_B, the three last lags of the treatment period are predictors. For Lag_C, the two lags closest to the pre-treatment mean are predictors. For Lag_x+vars, lag specification $\mathrm{x}$ and covariates are predictors.

Source: Microcensus 1995-2010. 
It is again interesting to note a drop in the share of migrants in the crafts sector in 2007/2008 that is not apparent in the difference-in-differences calculations in the original paper. Again, this is likely due to the financial crisis that worsened the general labor market situation in Germany in those years.

The income estimations are particularly interesting since here Fredriksen (2017) finds a result which is contrary to what the existing literature has claimed. Will the synthetic control estimation confirm no effect or will a negative effect of the deregulation emerge? The results show no decline in incomes as a result of removing occupational licensing in the German crafts sector (figure 6). If anything, there appears to be a rise in incomes in the specification where covariates are included as predictors (figure 6B).

Figure 6: Income gap between deregulated trades and synthetic control

\section{A: Only lags as predictors}

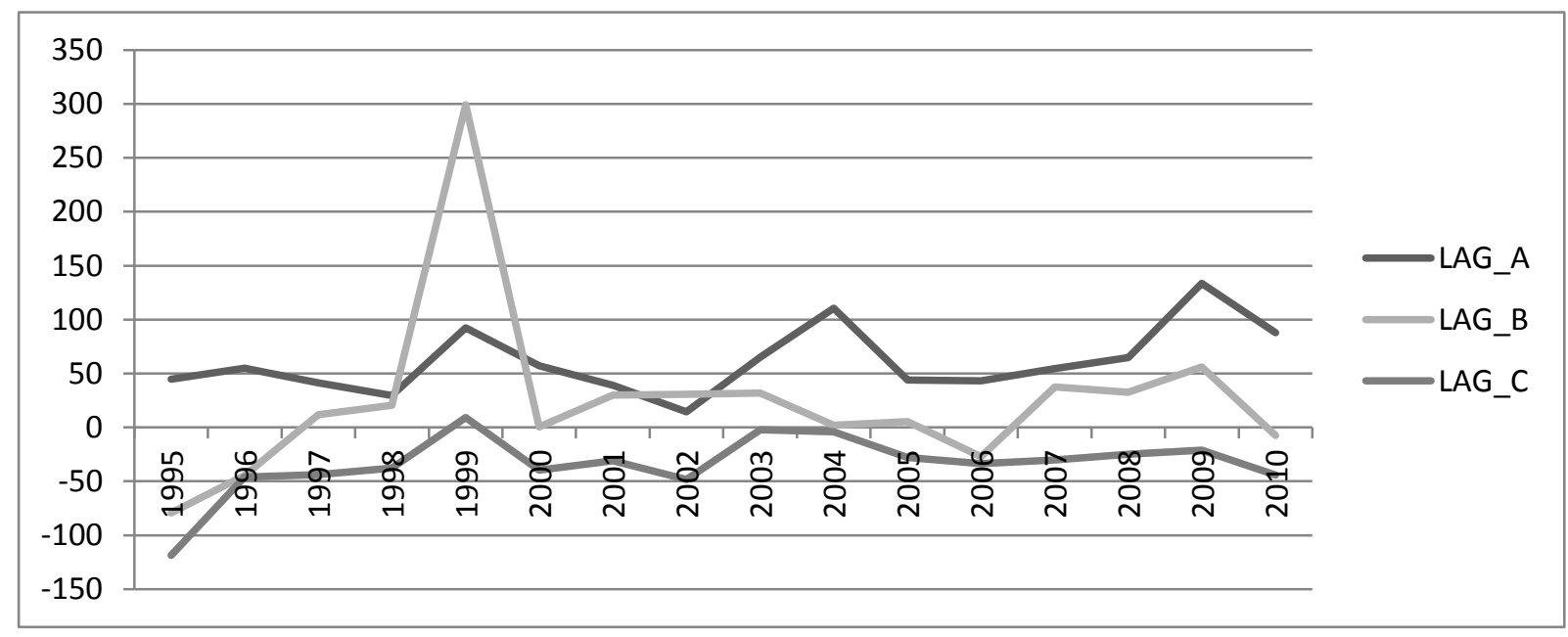


B: Both covariates and lags as predictors

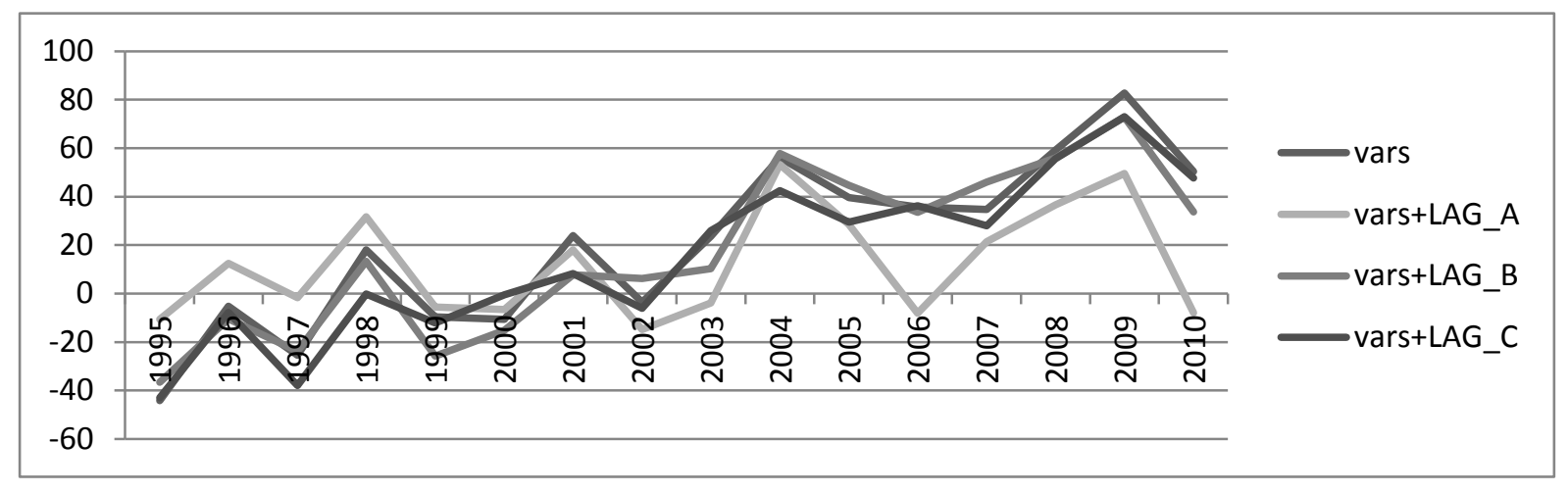

Note: For Lag_A, the first, middle and last lags of the outcome variable are predictors. For Lag_B, the three last lags of the treatment period are predictors. For Lag_C, the two lags closest to the pre-treatment mean are predictors. For Lag_x+vars, lag specification $\mathrm{x}$ and covariates are predictors.

Source: Microcensus 1995-2010.

The results in Fredriksen (2018) suggest that male craftsmen working in the construction sector may have been (as opposed to all craftsmen seen together) affected by the reform. However, the synthetic control specification on this particular sub-sample (not presented here) yields very erratic curves, which may again be due to the loss of power when reducing the sample and a rather poor pre-treatment fit and it is our assessment that this specification does not add to the analysis.

Notice that in the case of incomes, the fit in the pre-treatment years is generally not fully convincing. The income difference between the deregulated trades and their synthetic control is large and varies substantially as opposed to being a constant line equal to zero which is desirable. Additionally, the specification with only individual characteristics and no lags (not shown here) was immediately dropped because of the lack of pre-treatment fit. Abadie et al. (2015, p. 500) warn "we do not recommend using this [aka: Synthetic control] method when the pretreatment fit is poor".

There is no definition of "poor fit" in the context of synthetic control estimation. We therefore use a published study looking at incomes using synthetic control for reference. Peri and Yasinov (2018) in their analysis of the income effect of migration influx on incomes using synthetic control estimations obtain a maximum difference in the (log of) wage between the treatment- and synthetic control of about 0,07 points and characterize this pre-treatment fit as "reasonably good". In the case of the German crafts, the maximum difference in logs obtained 
is lower for all retained specifications, hence the pre-treatment fit is considered to be good enough to trust the results obtained.

\subsection{Senstivity analysis}

When we exclude the crafts occupations that were partially deregulated in 2004, our main results do not change, hence the donor-pool does not appear to contain treated units. The figures in annex 2 show that a reform-effect is still present for market entry and migrants whereas no effect is detected on incomes or market exits.

A number of placebo-test were furthermore conducted in order to check whether differences between treatment and control group can occur by pure chance. For these tests, similarly to the results presented before, the synthetic control method is applied successively to outcomes market entry, market exit, share of migrants and incomes. The donor pool consists of both fully regulated and partially deregulated crafts trades.

However, this time the treatment groups are all of the in reality untreated observations. This makes for a lot of treatment effects as the number of control occupations is large. We remove from the result figures placebo-interventions where the pre-treatment fit is particularly poor based on a comparison of their mean and standard deviation in the pre-treatment period to that of the true treatment group. This not only increases the visual interpretability of the resulting graphics, it is also in line with Abadie et al. (2010, p. 502) that point out that such placebo estimations ,do not provide information to measure the relative rarity of estimating a large post-intervention gap“.

The placebo-tests confirm the main findings in this paper. The gray lines in the graphs show the difference in outcome between each occupation in the donor pool and its respective synthetic version. The superimposed black line denotes this gap for the actual treatment group.

In the case of market entry, figure 7 shows that the true treatment effect shows one of the strongest increases compared to the synthetic control in the post-treatment period. In the case of market exit, figure 8 shows that the true treatment group does not stand out compared to the placebo-interventions. An exception to this are the last two years of the period under consideration where market exits in the true treatment group increase markedly compared to their synthetic control. However, whether this is due to the reform is uncertain since a time lapse of 5 years is considerable. 
Figure 7: Gaps in the share of market entries in deregulated trades compared to synthetic control for 32 placebo interventions

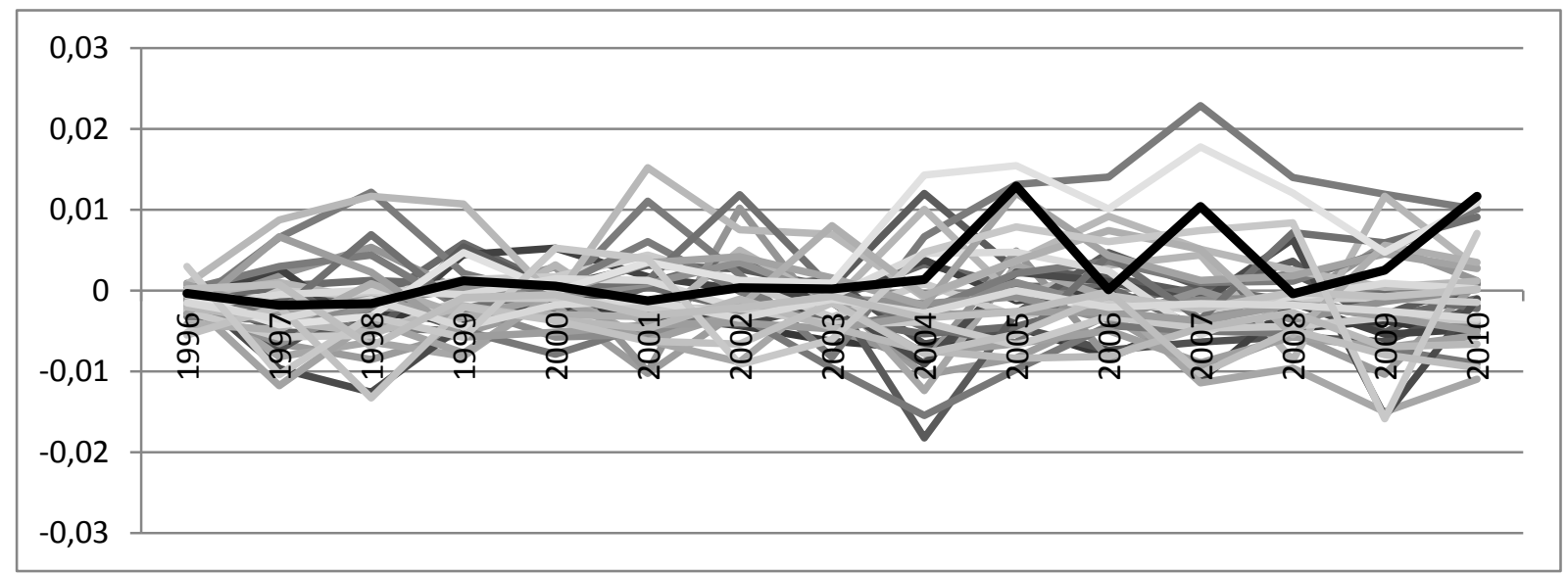

Note: The predictor specification used is the combination of lagged outcome variables and covariates that yielded the lowest RMSPE.

Source: Microcensus 1995-2010.

Figure 8: Gaps in the share of market exits in deregulated trades compared to synthetic control for 28 placebo interventions

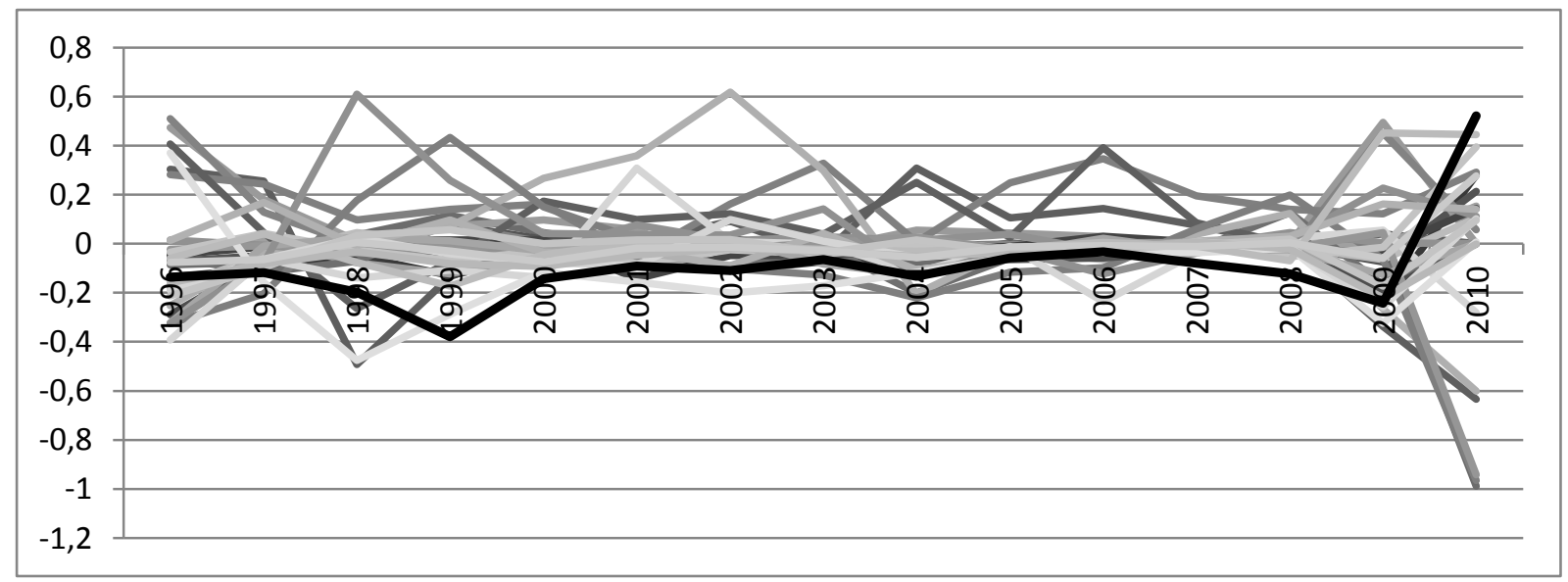

Note: The predictor specification used is the combination of lagged outcome variables and covariates that yielded the lowest RMSPE.

Source: Microcensus 1995-2010.

In the case of migrants, the placebo-test also suggests that the estimated treatment effect is a true treatment effect (see figure 9 and figure 10). These calculations for the sub-sample of untrained employees are left out as the calculations showed no treatment-effect for this group. The estimated gap for the deregulated trades during the post-treatment period is unusually 
large relative to the distribution of the gaps for non-affected occupations, a finding which is particularly true for all migrant employees.

Figure 9: Gaps in the share of self-employed migrants in deregulated trades compared to synthetic control for 31 placebo interventions

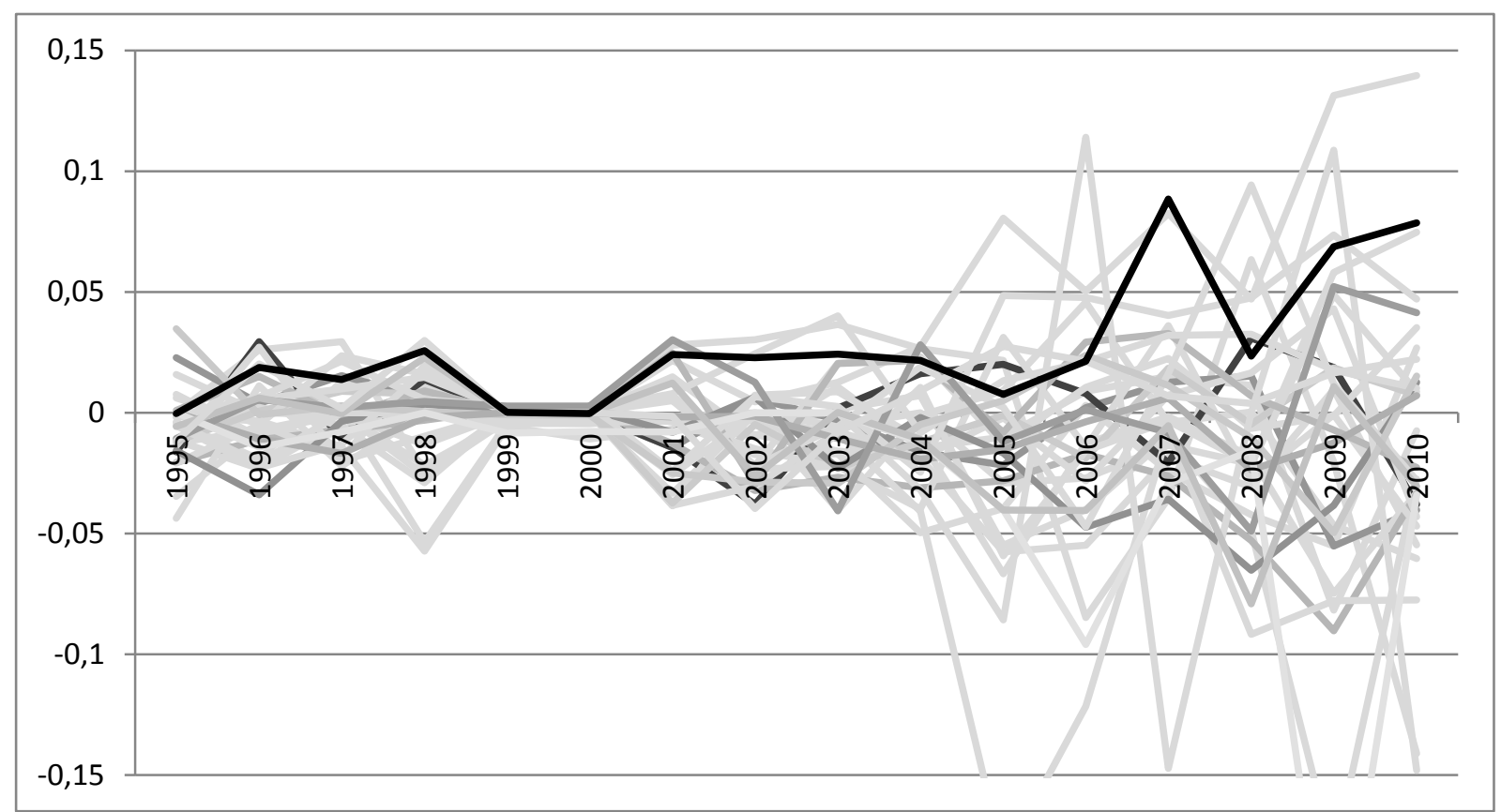

Note: The predictor specification used is the combination of lagged outcome variables and covariates that yielded the lowest RMSPE.

Source: Microcensus 1995-2010. 
Figure 10: Gaps in the share of migrant employees in deregulated trades compared to synthetic control for 59 placebo interventions

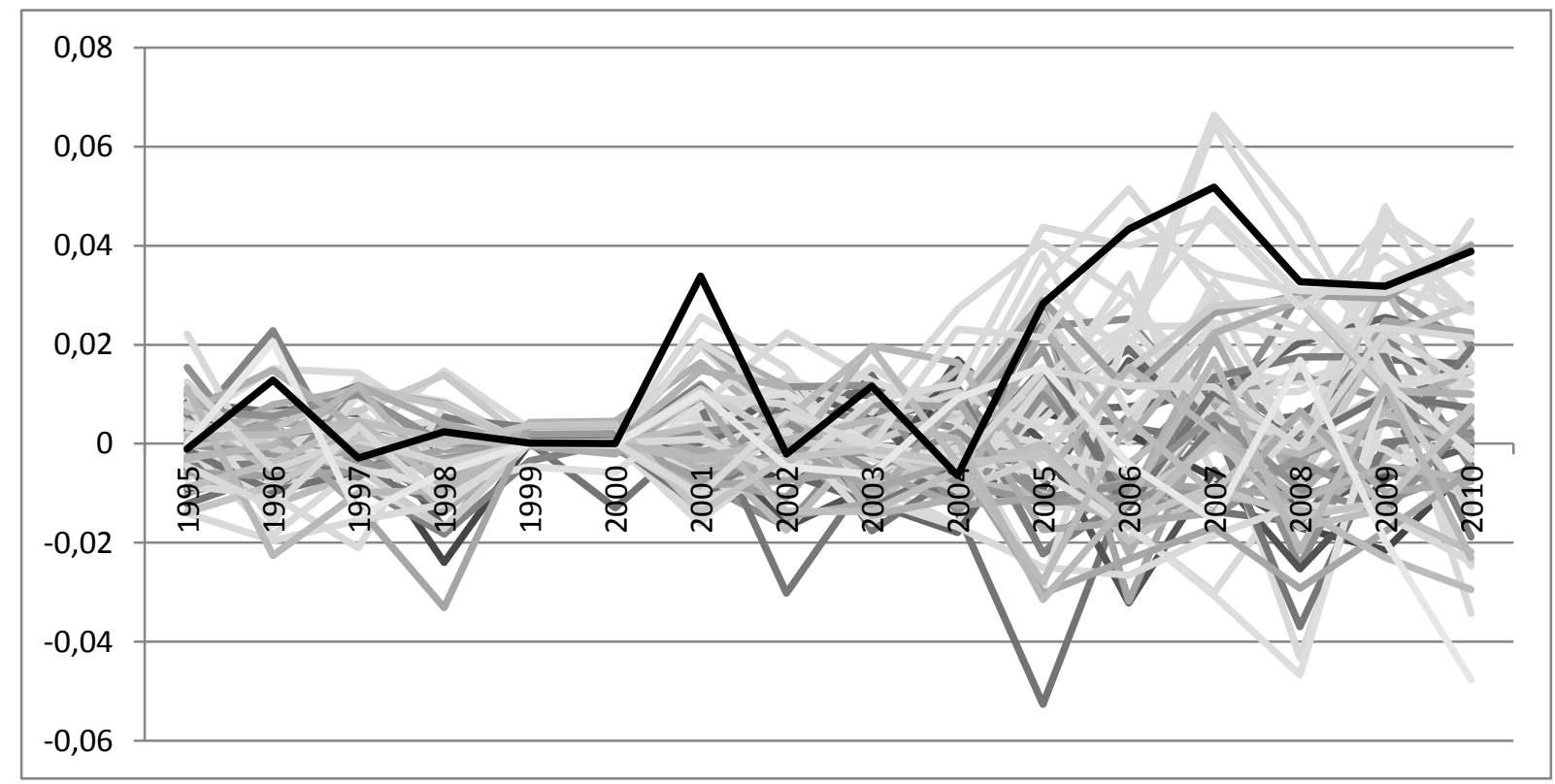

Note: The predictor specification used is the combination of lagged outcome variables and covariates that yielded the lowest RMSPE.

Source: Microcensus 1995-2010.

A placebo-test in the case of incomes seems less necessary as a treatment-effect could not be detected in the first place. Since an effect of occupational licensing on incomes has often been found in the literature, we however still present the placebo calculations in figure 11. Again, the true treatment group is represented by the black line. It appears evident that removing occupational licensing has not led to a decrease in incomes in deregulated trades, as one could have expected based on existing studies on occupational licensing. Possible reasons explaining this finding are detailed in Fredriksen (2018). 
Figure 11: Income gaps to synthetic control for deregulated crafts trades and 35 placebo interventions

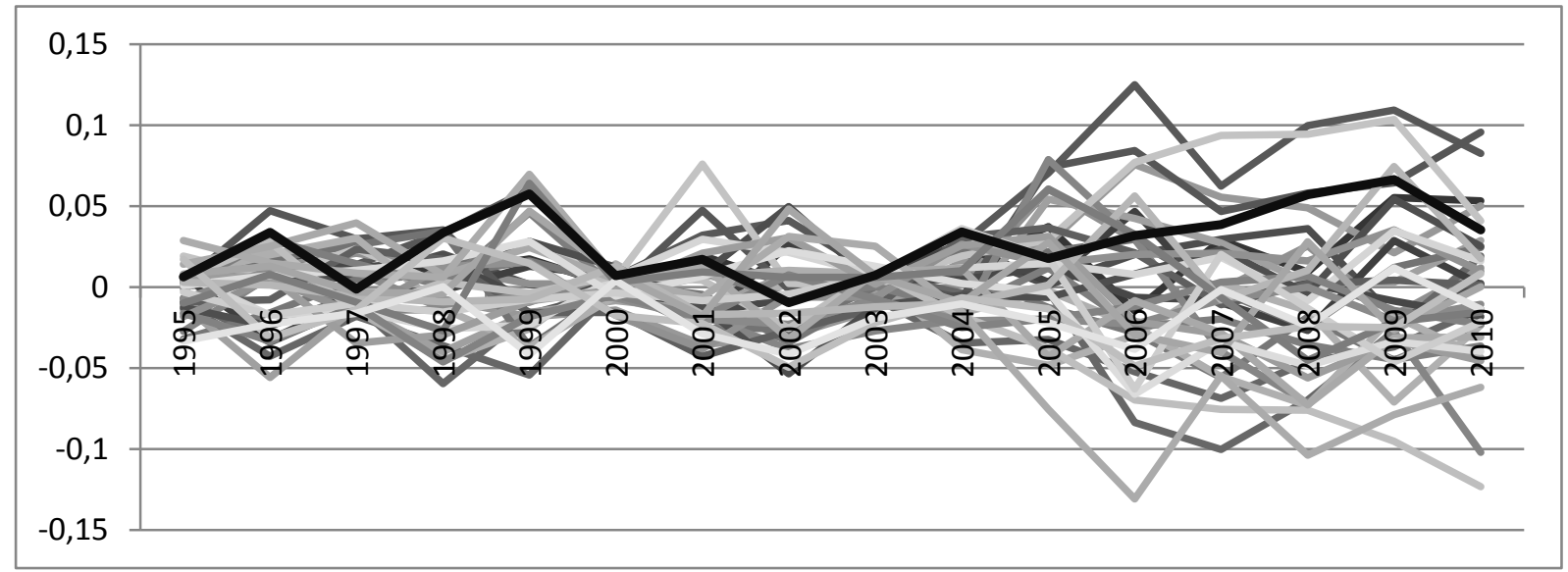

Note: The predictor specification used is the combination of lagged outcome variables and covariates that yielded the lowest RMSPE.

Source: Microcensus 1995-2010.

\section{Conclusion}

Using adequate comparison units is crucial in policy evaluation studies. If comparison units are not sufficiently similar to those subjected to the intervention of interest, any difference in the outcomes may simply be due to different characteristics of the groups.

O'Neill et al. (2016) find that there is no one policy evaluation methodology that delivers correct results in every situation. Based on this, the authors recommends "that the base case analysis should present results from the method(s) that uses the 'most plausible' identification assumption, but then the sensitivity analysis should present findings from method(s) that make alternative, but still 'somewhat plausible' identification assumption.

This paper has tried to accommodate the second part of this quote. Three existing studies looking into economic effects of removing occupational licensing regulation in certain German crafts trades in 2004 using difference-in-differences estimation are replicated using the synthetic control method. The latter methodology is an interesting tool to gauge the effects of economic policies since it constructs based on available data the best possible counterfactual and makes apparent whether an appropriate control could be created or not. Overall, using synthetic control estimation does not significantly alter conclusions drawn based on difference-in-differences estimations (table 4). 
Table 4: Reform effects using synthetic control versus difference-in-differences

\begin{tabular}{|l|l|l|}
\hline \multicolumn{1}{|c|}{ Outcome } & \multicolumn{1}{c|}{$\begin{array}{c}\text { Difference-in-differences } \\
\text { estimation }\end{array}$} & \multicolumn{1}{|c|}{ Synthetic control estimation } \\
\hline Market entry & Increase & Increase \\
\hline Market exit & Increase & No effect \\
\hline Migrant self-employment & Increase & Increase \\
\hline Migrant employment & Increase & Increase \\
\hline $\begin{array}{l}\text { Migrant untrained } \\
\text { employment }\end{array}$ & Increase & No effect \\
\hline Incomes & No effect & No effect \\
\hline
\end{tabular}

However, using a different methodology has provided some interesting new insights. Firstly, additional information was revealed regarding the negative effects of a general economic downturn on market entry in the crafts sector and migrant integration via the crafts. Secondly, the positive effect on market exit found in the original study does not appear to be robust. The reform-effect on market exits has been contested in the literature. The findings in this study confirm those in Rostam-Afschar (2014), the first study to use difference-in-differences in order to estimate the effects of the 2004-deregulation, that did not pick up any effect on exits. It should however be mentioned that the increase in exit found in Runst et al. (forthcoming) primarily stem from a specification using a different dataset. An alternative conclusion could therefore be that the microcensus is not suited to study market exits in the crafts. Thirdly, the previous finding that reform effects have been concentrated on untrained migrants could not be confirmed.

Finally, it is interesting to note that while difference-in-differences appears appropriate to study the deregulation in 2004, referring to the reform as a "natural experiment in the crafts sector" as Damelang et al. (2017) does is not correct. In fact, using a more transparent method like synthetic control estimation reveals that non-crafts occupations appear to be the better counterfactual. This shows that the issue of the counterfactual may be trickier than one might expect. 


\section{Literature}

Abadie, A. and Gardeazabal, J. (2003), "The Economic Costs of Conflict: A Case Study of the Basque Country”, in: American Economic Review, 93(1), 113-132.

Abadie, A., Diamond, A. and Hainmueller, J. (2010), "Synthetic Control Methods for Comparative Case Studies: Estimating the Effect of California's Tobacco Control Program", in: Journal of the American Statistical Association 105(490), 493-505.

Abadie, A., Diamond, A. and Hainmueller, J. (2015), "Comparative Politics and the Synthetic Control Method", in: American Journal of Political Science 59(2), 495-510.

Angrist, J.D. and Pischke, J.S. (2009), "Mostly Harmless Econometrics: An Empiricist's Companion", in: The Stata Journal 2(4), 358-377.

Athey, S. and Imbens, G.W. (2006), "Identification and Inference in Nonlinear Difference-inDifference Models", in: Econometrica 74(2), 431-74.

Bertrand, M., Duflo, E. and Mullainathan, M. (2004), "How much should we trust differencein-differences estimates?”, in: Quarterly Journal of Economics 119(1), 249-275.

Damelang, A., Haupt, A. and Abraham, M. (2017), „Economic consequences of occupational deregulation: Natural experiment in the German crafts", in: Acta Sociologica, 1-16.

Dehejia, R. and Wahba, S. (1999), "Casual Effects in Nonexperimental Studies: Reevaluating the Evaluation of Training Programs", in; Journal of the American Statistical Association, 94(448), 1053-1062.

Dehejia, R. and Wahba, S. (2002), "Propensity Score-Matching Methods for Nonexperimental Causal Studies", in; The Review of Economics and Statistics, 84(1), 151-161.

Fredriksen, K. (2018), "Does occupational licensing really impact incomes? - The German crafts case", Ifh Working Paper Series.

Hahn, J. and Shi, R. (2017), "Synthetic Control and Inference”, in: Econometrics, 5(4), 52.

Heckman, J. (1997), "Matching as an econometric evaluation estimator: Evidence from evaluating a job training program", in: Review of Economic Studies 64(4), 605-654.

Kaul, A., Kloessner, S., Pfeifer, G, and Schieler, M. (2016), "Synthetic Control Methods: Never Use All Pre-Intervention Outcomes as Economic Predictors", Working paper. Saarbuecken, Germany: Saarland University.

Kleiner, M (2006), “Licensing Occupations: Ensuring Quality or Restricting Competition?" Kalamazoo, MI: W.E. Upjohn Institute for Employment Research.

Kleiner, M. M. (2015), "Border Battles: The Influence of Occupational Licensing on Interstate Migration", in: Employment Research Newsletter, 22(4), 4-6, W.E. Upjohn Institute for Employment Research.

Kleiner, M. and Kudrle, R. (2000), „Does Regulation Affect Economic Outcomes? The case of Dentistry", in: Journal of Law and Economics 43(2), 547-582.

Kleiner, M. and Krueger, A. (2010), „The Prevalence and Effects of Occupational Licensing”, in: British Journal of Industrial Relations 48(4), 676-687. 
Koch, A. and Nielen, S. (2016), "Oekonomische Effekte der Liberalisierung der Handwerksordnung von 2004”, in: WISO Diskurs 05/2016, Friedrich Ebert Stiftung.

Kreif, N., Grieve, R., Hangartner, D., Turner, A.J., Nikolova, N. and Sutton, M. (2016), "Examination of the Synthetic Control Method for Evaluating Health Policies with Multiple Treated Units", in: Health Economics 25, 1514-1528.

Law, M. T. and Marks, M. S. (2009), "Effects of Occupational Licensing Laws on Minorities: Evidence from the Progressive Era", in: Journal of Law and Economic, 52, 351-366.

Lergetporer, P., Ruhose, J. and Simon, L. (2016), „Labor Market Effects of Entry Barriers to Self-Employment: Evidence from Deregulating the German Crafts Sector", Ifo Center for the Economics of Education, Ifo Institute.

McClelland, R. and Gault, S. (2017), "The Synthetic Control Method as a Tool to Understand State Policy", Research Report, Urban Institute.

O’Neill, S. Kreif, N., Grieve, R., Sutton, M. and Sekhon, J. (2016), "Estimating casual effects: Considering three alternatives to difference-in-differences estimation", in: Health Services Outcomes Research Methodology 16, 1-21.

Pashigian, P. B. (1979), "Occupational Licensing and the Interstate Mobility of Professionals", in: The Journal of Law \& Economics, 22(1), 1-25.

Peri, G. and Yasenov, V. (2018), “The Labor Market Effects of a Refugee Wave: Synthetic Control Method Meets the Mariel Boatlift", in: The Journal of Human Resources, published online before print.

Rostam-Afschar, D. (2014), "Regulatory Effects of the Amendment to the HwO in 2004 in German craftsmanship”, in: Empirical Economics 47, 1067-1101.

Rottenberg, S. (1962), „The Economics of Occupational Licensing“, in: Aspects of Labor Economics, Princeton University Press, 3-20.

Runst, P. (2018), "Does the Deregulation of Occupational Licensing affect the Labor Market Participation of Migrants in Germany?", in: European Journal of Law and Economics, 45(3), 555-589.

Runst, P., Thomä, J., Haverkamp, K. and Müller, K. (forthcoming), “A replication of 'Entry regulation and entrepreneurship: a natural experiment in German craftsmanship", in: Empirical Economics.

Rubin, D. (1976), “Inference and missing data”, in: Biometrika 63(4), 581-592.

Rubin, D. (1974), "Estimating casual effects of treatments in randomized and nonrandomized studies”, in: Journal of Educational Psychology 66, 688-701.

Ryan, A.M., Burgess, J.F. and Dimick, J.B. (2015), "Why we shouldn't be indifferent to specification in difference-in-differences models", in: Health Service Research 50(4), 1211-1235.

Tullock, G. (2004), “The Selected Works of Gordon Tullock, Vol. 1: Virginia Political Economy", edited by Charles K. Rowley. Liberty Fund, Indianapolis.

Zwiener, S. (2017), "Essays on the German Labor Market", Dissertation Humboldt University, Berlin. 
Annex 1: Composition of the synthetic control

The following tables show composition of the synthetic control for the specification with the lowest RMSPE both solely comprising of lags and the best-treatment fit with both lags and other covariates. Occupations that contribute to less than $1 \%$ of the synthetic control are not included.

Table A.1: Market entry

\begin{tabular}{lc|lc}
\multicolumn{2}{c|}{ LAG_A } & \multicolumn{2}{c}{ vars+LAG_A } \\
\hline Occupation & Weight & Occupation & Weight \\
Non-crafts & 61,2 & Non-crafts & 77,3 \\
& & Butcher & 6,8 \\
& & Plasterer & 9,3 \\
& & Chimney & 6,1 \\
\hline Sum & & sweeper & 100
\end{tabular}

Source: Microcensus 1996-2010. 
Table A.2: Market exit

\begin{tabular}{|c|c|c|c|}
\hline \multicolumn{2}{|l|}{ LAG_C } & \multicolumn{2}{|l|}{ vars+LAG_C } \\
\hline Occupation & Weight & Occupation & Weight \\
\hline Non-crafts & 0 & Non-crafts & 0 \\
\hline Precision mechanic & 1,7 & Precision mechanics & 5,5 \\
\hline Metal worker & 2,2 & $\begin{array}{l}\text { Installer and heating } \\
\text { manufacturer }\end{array}$ & 29 \\
\hline Plumber & 3,1 & Dispensing optician & 11,6 \\
\hline Installer and heating manufacturer & 3,1 & Electrical technician & 3,9 \\
\hline Automotive technician & 3,1 & Electrical engine manufacturer & 1,6 \\
\hline $\begin{array}{l}\text { Mechanic for agricultural and } \\
\text { construction machinery }\end{array}$ & 2,9 & Baker & 4,7 \\
\hline Gunsmith & 2,7 & Hairdresser & 43,7 \\
\hline Dental technician & 3,4 & & \\
\hline Dispensing optician & 3,6 & & \\
\hline Orthopaedic technician & 1,8 & & \\
\hline Electrical technician & 3,8 & & \\
\hline Electrical engine manufacturer & 2,3 & & \\
\hline Hearing aid acousitician & 3,1 & & \\
\hline Communication technician & 1,3 & & \\
\hline Baker & 3,5 & & \\
\hline Butcher & 27,1 & & \\
\hline Oven and air heating manufacturer & 2,3 & & \\
\hline Hearing aid acousitician & 1,6 & & \\
\hline Roadbuilder & 2 & & \\
\hline Thermal and acousticinsulation fitter & 3,3 & & \\
\hline Glazier & 2,3 & & \\
\hline Carpenter & 4,5 & & \\
\hline Roof tiler & 2,8 & & \\
\hline Joiner & 4,6 & & \\
\hline Hairdresser & 4,5 & & \\
\hline Sum & 97 & Sum & 100 \\
\hline
\end{tabular}

Source: Microcensus 1996-2010. 
Table A.3: Migrants- Self-employed

\begin{tabular}{lc|lc} 
& LAG_B & \multicolumn{2}{c}{ vars+LAG_A } \\
\hline Occupation & Weight & Occupation & Weight \\
Non-crafts & 2,1 & Non-crafts & Mechanic for tyres and \\
& & vulcanization & 40 \\
& & Gunsmith & 1,1 \\
\hline Sum & 2 & Sum & 4,9 \\
\hline
\end{tabular}

Source: Microcensus 1995-2010.

Table A.4: Migrants- All employees

\begin{tabular}{lc|lc}
\multicolumn{2}{c|}{ LAG_C } & \multicolumn{2}{c}{ vars+LAG_C } \\
\hline Occupation & Weight & Occupation & Weight \\
Non-crafts & 28,1 & Non-crafts & 43,7 \\
\hline Sum & 28 & Sum & 44
\end{tabular}

Source: Microcensus 1995-2010.

Table A.5: Migrants- Untrained employees

\begin{tabular}{lc|lc}
\multicolumn{1}{c|}{ LAG_B } & \multicolumn{2}{c}{ vars+LAG_B } \\
\hline Occupation & Weight & Occupation & Weight \\
Non-crafts & 24,7 & Non-crafts & 45,2 \\
& & Mechanic for tyres and & 1,1 \\
& & vulcanization & Precision mechanic \\
\hline Sum & 25 & Sum & 53 \\
Source: Microcensus $1995-2010$. & & &
\end{tabular}

Table A.6: Incomes

\begin{tabular}{|c|c|c|c|}
\hline \multicolumn{2}{|l|}{ LAG_A } & \multicolumn{2}{|l|}{ vars+LAG } \\
\hline & Weigh & & Weigh \\
\hline Occupation & $\mathrm{t}$ & Occupation & $\mathrm{t}$ \\
\hline Non-crafts & 30 & Non-crafts & 24,4 \\
\hline & & Glass blower and glass apparatus & \\
\hline Glass blower and glass apparatus builder & 16,4 & $\begin{array}{l}\text { builder } \\
\text { Metalworker }\end{array}$ & $\begin{array}{l}6,7 \\
12\end{array}$ \\
\hline & & Coachbuilder & 1,9 \\
\hline & & Gunsmith & 36,1 \\
\hline & & Orthopaedic technician & 6,4 \\
\hline & & Painter and laquerer & 2,9 \\
\hline Sum & 46 & Sum & 80 \\
\hline
\end{tabular}

Source: Microcensus 1995-2010. 


\section{Annex 2: Composition of the donor pool}

The following figures show the gap between the deregulated trades and their synthetic control when the trades that where partially deregulated in 2004 (referred to as A-trades) are excluded from the donor pool.

Figure A.1: Market entry

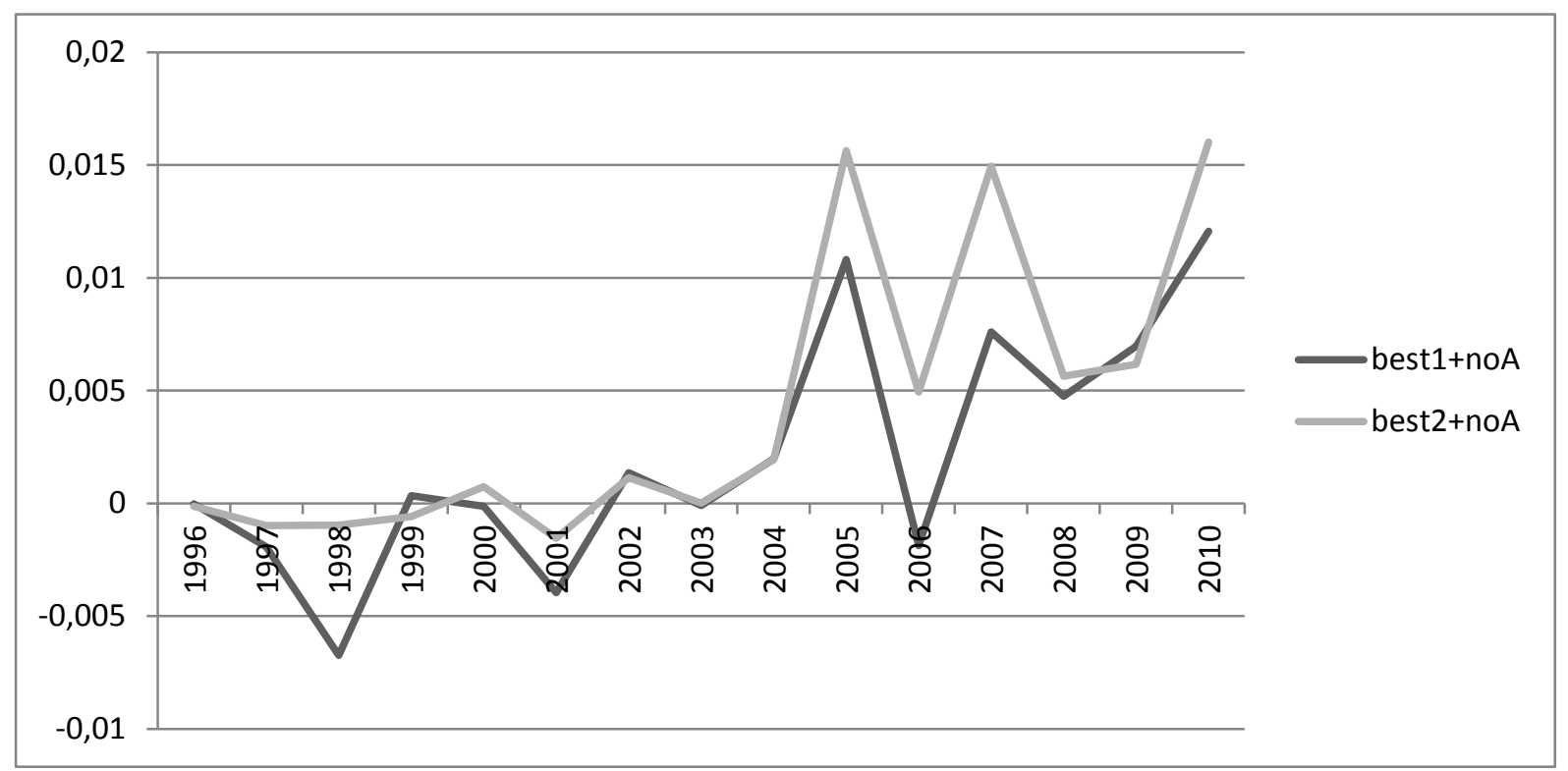

Note: Note: Best1 refers to the specification with only lagged outcome variables as predictors that achieved the lowest RMSPE. Best 2 refers to the specification with lagged outcome variables and covariates that achieved the lowest RMSPE:

Source: Microcensus 1996-2010. 
Figure A.2: Market exit

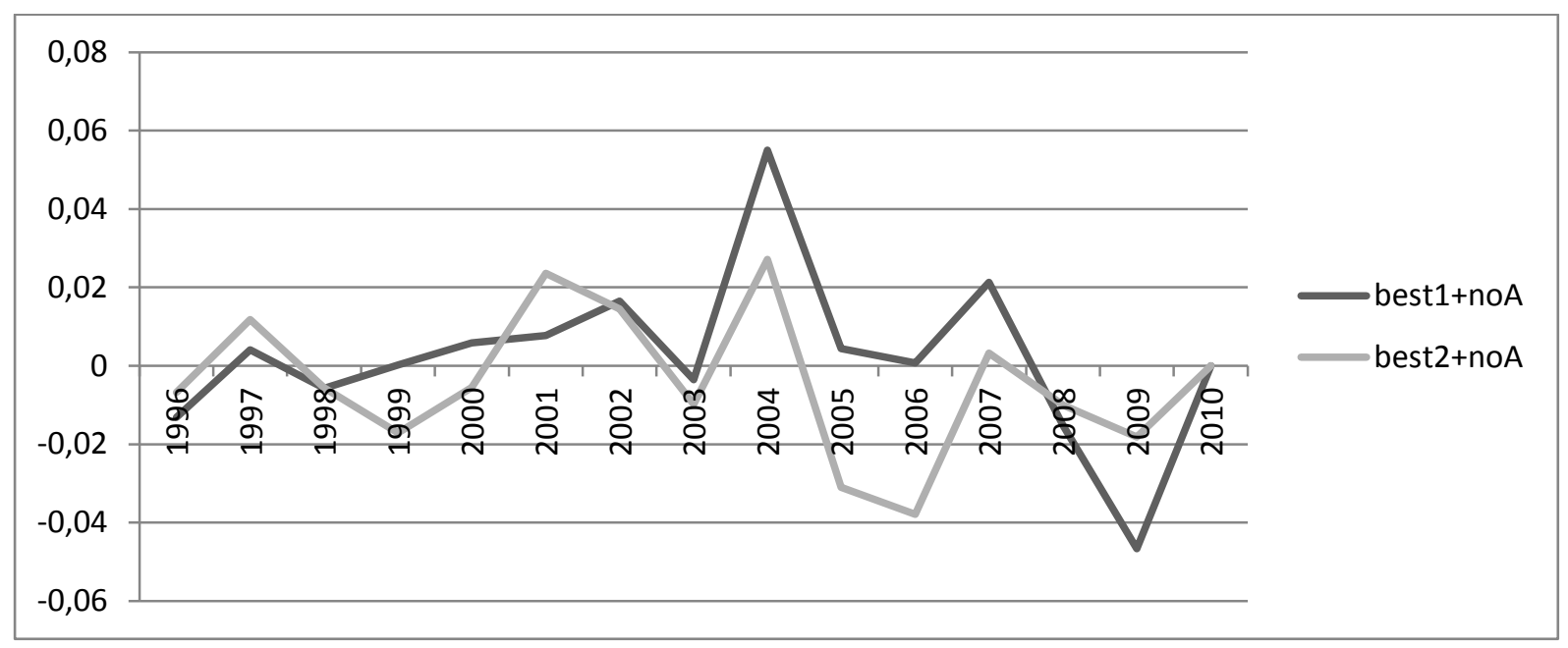

Note: Note: Best1 refers to the specification with only lagged outcome variables as predictors that achieved the lowest RMSPE. Best 2 refers to the specification with lagged outcome variables and covariates that achieved the lowest RMSPE:

Source: Microcensus 1996-2010.

Figure A.3: Migrants- Self-employed

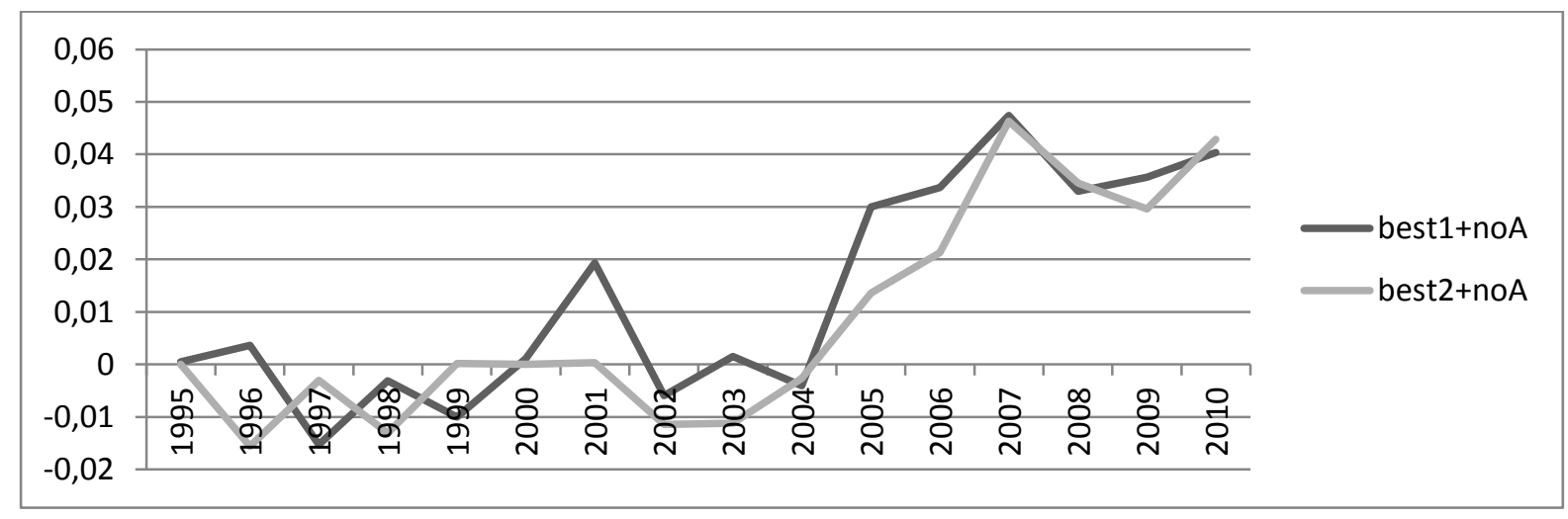

Source: Microcensus 1995-2010. 
Figure A.4: Migrants- Employees

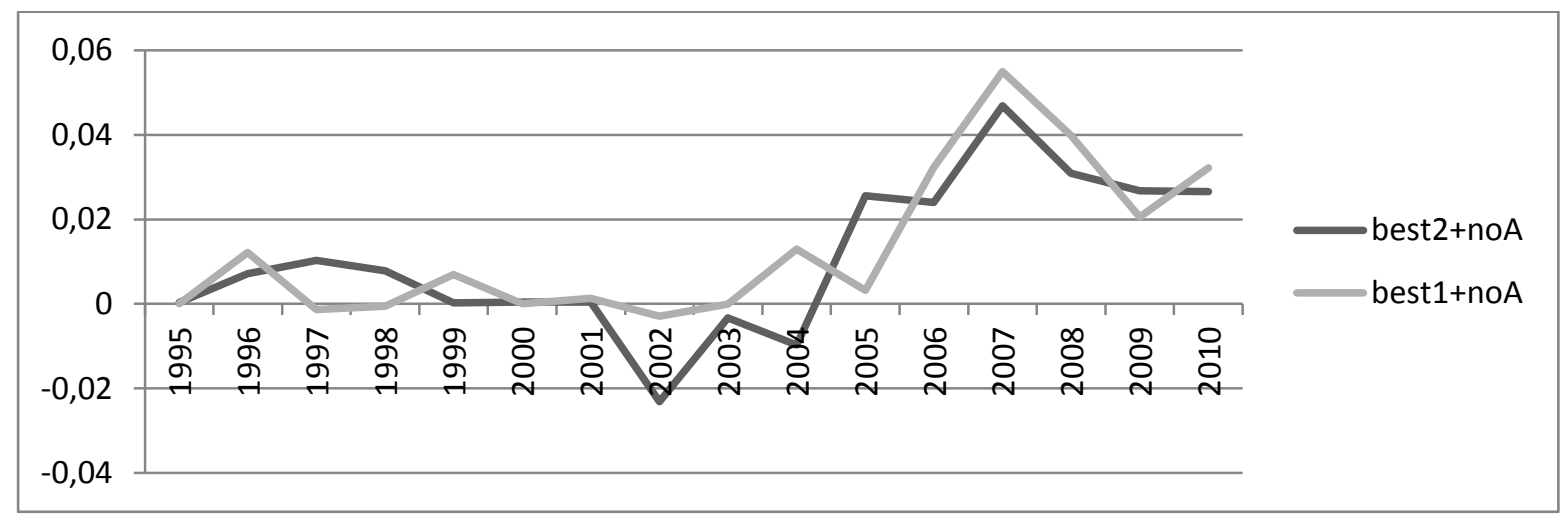

Source: Microcensus 1995-2010.

Figure A.5: Incomes

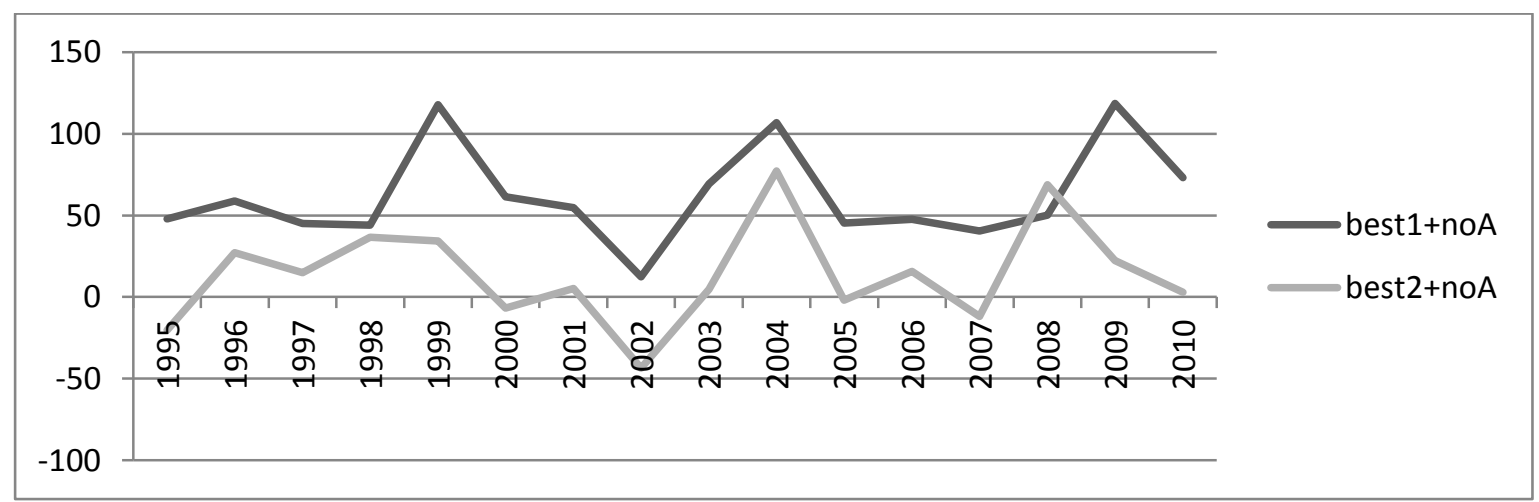

Note: Note: Best1 refers to the specification with only lagged outcome variables as predictors that achieved the lowest RMSPE. Best2 refers to the specification with lagged outcome variables and covariates that achieved the lowest RMSPE:

Source: Microcensus 1995-2010. 


\section{Chapter V: Ökonomische Effekte der Deregulierung der Handwerksordnung im Jahr 2004 - ein Literaturüberblick}

(with Petrik Runst, Till Proeger, Katarzyna Haverkamp and Jörg Thomä)

Published in: Wirtschaftsdienst - Zeitschrift für Wirtschaftspolitik, 98(5): 365-371, Copyright

(C) ZBW und Springer-Verlag Berlin Heidelberg with title "Handwerksordnung: ökonomische Effekte der Deregulierung von 2004"

DOI: $10.007 / \mathrm{s} 10273-018-2301-\mathrm{z}$

Purchase/read online abstract:

https://archiv.wirtschaftsdienst.eu/jahr/2018/5/handwerksordnung-oekonomische-effekte-derderegulierung-von-2004/ 
Zusammenfassung: Die deutsche Handwerksordnung regelt die Unternehmensgründung in handwerklichen Berufen durch die Vorgabe verpflichtender Qualifikationsstandards. Im Jahr 2004 wurde der Marktzugang im Handwerk durch eine Novellierung der Handwerksordnung dereguliert, sodass für mehr als die Hälfte aller Handwerksberufe seitdem keine Meisterpflicht mehr gilt. Seit der Reform wird eine politische und wissenschaftliche Diskussion zu den einzel- und gesamtwirtschaftlichen Effekten dieser Deregulierung geführt. Fast fünfzehn Jahre nach der Deregulierung können aus den bisherigen Studien grundlegende Effekte abgeleitet werden und Forschungslücken definiert werden, um die weitere wirtschaftspolitische Diskussion wissenschaftlich zu fundieren. Der vorliegende Artikel fasst dafür die theoretischen Grundpositionen und die empirischen Studien zur Entwicklung des deutschen Handwerkssektors nach der Deregulierung zusammen und formuliert anschließend zu schließende Forschungslücken zur umfassenden wirtschaftspolitischen Bewertung der Handwerksreform.

Abstract: The German Trade and Crafts Code constitutes the regulatory framework for entrepreneurial activities in the crafts sector. Among other things, it prescribes mandatory qualification standards for starting a new craft firm. In 2004, the Trade and Crafts Code, and in particular, market entry, was liberalized so that qualification standards are no longer required in about half of all crafts occupations. Since this reform was implemented, there has been a vivid political and academic discussion about the economic effects. Almost fifteen years after, we summarize the empirical research literature. Further, we identify gaps in the literature and formulate open research questions.

JEL: L15, L51, J44, J48, O52 


\section{Einleitung}

Die deutsche Handwerksordnung regelt den handwerklichen Sektor der deutschen Volkswirtschaft, unter anderem in Hinblick auf Ausbildungsstandards und den Marktzugang neuer Unternehmen. Eine zentrale Steuergröße liegt im Erwerb des Meisterbriefs als qualifikatorischem Standard. Dieser war bis zum Jahr 2004 für die aktuell 93 Gewerbe des Handwerks mit wenigen Ausnahmen die Voraussetzung zur Gründung und Führung eines Betriebes sowie zur Ausbildung von Gesellen. Im Zuge der sog. Hartz-Reformen erfolgten 2004 zum einen eine Deregulierung von 52 dieser nunmehr sogenannten „B1-Handwerke“632, in denen die Meisterpflicht komplett entfiel, sowie zum anderen Ausnahmeregelungen in fast allen verbleibenden sogenannten „A-Handwerken“, die einer leichten Deregulierung entsprechen. Insgesamt wurde also der Marktzugang im Handwerkssektor teilweise dereguliert. ${ }^{33}$

Die politische Diskussion über die Effekte der Deregulierung und dabei insbesondere über den Wegfall der Meisterpflicht hält weiterhin an: Während die Europäische Kommission an einer weitergehenden Marktöffnung zum Ausbau eines europäischen Binnenmarkts für Handwerksdienstleistungen arbeitet ${ }^{34}$, fordern verschiedene politische Akteure in Deutschland die Prüfung einer Rückabwicklung der Deregulierung und einer Wiedereinführung qualifikationsgebundener Markteintrittsschranken.

In Folge der anhaltenden politischen Diskussion entwickelte sich in den vergangenen Jahren ein verstärktes Interesse an den ökonomischen Effekten der Deregulierung. Der vorliegende Beitrag fasst die theoretischen Argumente und den aktuellen Stand der empirischen Evidenz zusammen und schafft so einen kompakten Überblick für die künftige wirtschaftspolitische Debatte. Hierfür werden zunächst die zwei zentralen theoretischen Zugänge hinsichtlich der Reformeffekte gegenübergestellt, dann die empirischen Studien zu den Reformeffekten zusammengefasst und schließlich eine Zusammenfassung und weiterer Forschungsbedarf formuliert.

\footnotetext{
${ }^{32}$ Der Name bezieht sich auf die Anlage B1 der Handwerksordnung, in welcher die vollständig deregulierten Handwerkszweige aufgelistet sind. Weiterhin gibt es die Anlage B2, in der handwerksähnliche Gewerbe aufgeführt sind, die nie einer Meisterpflicht unterlagen.

${ }^{33}$ Für Details siehe K. Müller: Erste Auswirkungen der Novellierung der Handwerksordnung von 2004, in: Göttinger Handwerkswirtschaftliche Studien (2016), H. 74, ifh Göttingen sowie P. Runst et al.: A replication of ,Entry regulation and entrepreneurship. A natural experiment in German craftmanship', in: Empirical Economics (i.E.).

${ }^{34}$ EU-Kommission: Mitteilung der Kommission an das europäische Parlament, den Rat und den europäischen Wirtschafts- und Sozialausschuss. Bewertung der nationalen Reglementierungen des Berufszugangs, COM 2013/676 final vom 02.10.2013, Brüssel 2013.
} 


\section{Theoretische Zugänge}

Die Frage nach der Notwendigkeit von Marktzugangsbeschränkungen im Handwerkssektor wird vor allem auf Basis zweier theoretischer Perspektiven analysiert, die konträre Grundpositionen einnehmen. Auf der einen Seite steht die Wettbewerbsperspektive, welche staatlichen Regulierungstatbeständen grundsätzlich kritisch gegenübersteht. Der zweite relevante Ansatz nimmt eine Marktversagens-Perspektive ein, welche die Existenz von Informationsasymmetrien als Marktversagenstatbestand betont. ${ }^{35}$

\subsection{Wettbewerbsperspektive}

Die Wettbewerbsperspektive ${ }^{36}$ nimmt an, dass Marktzutrittsschranken vor allem Ziel und Folge branchenbezogener Lobbyarbeit zur Erzielung von Monopolrenten sind. Eine zentrale Annahme dieser Perspektive ist, dass auf Handwerksmärkten kein Marktversagen vorliegt, bzw. dass im Fall asymmetrischer Informationsverteilung zwischen Produzenten und Konsumenten marktendogene Mechanismen einen Ausgleich der Informationslage bewirken können. Unter dieser Bedingung haben berufsbezogene Zugangsbeschränkungen Wohlfahrtsverluste zur Folge. Im regulierten Markt stellt die Meisterpflicht somit eine Markteintrittsbarriere dar, die als Fix-Kosten-Term für potentielle Unternehmen zu verstehen ist. Wenn der potentielle Unternehmer die Fix-Kosten der geforderten Qualifikation nicht tragen kann oder will, ist es ihm untersagt, ein Unternehmen zu gründen. Über einem bestimmten Kostenniveau verhindert die Meisterpflicht damit den Zugang von Unternehmen - je höher die Marktzugangskosten, desto geringer ist die Anzahl der Anbieter auf dem Markt. Wenn die Anzahl der Unternehmen gering ist, steigen die Preise über die Grenzkosten und es entsteht eine Monopolrente bei insgesamt sozial ineffizienter realisierter Menge. Die fehlende

\footnotetext{
${ }^{35}$ Vgl. für die grundlegende Unterscheidung vgl. im Folgenden: A. Haupt, N. Witte: Occupational Licensing and the Wage Structure in Germany, in: KIT Working Paper Series in Sociology (2016), H. 4. sowie S. Svorny: Licensing, market entry regulation, in: B. Bouckaert, G. De Geest (Hrsg.): Encyclopedia of Law and Economics Volume III: The Regulation of Contracts, Cheltenham 2000, S. 296-328.

${ }^{36}$ Die folgenden ökonomischen Grundannahmen zur Wettbewerbsperspektive basieren auf Branstetter et al.: Do Entry Regulations Deter Entrepreneurship and Job Creation? Evidence from Recent Reforms in Portugal, in: The Economic Journal, 124. Jg. (2014), H. 577, S. 805-832; M. M. Kleiner: Licensing occupations. ensuring quality or restricting competition? Kalamazoo, Michigan: W.E. Upjohn Institute for Employment Research (2006a); S. Svorny: Licensing, market entry regulation, in: B. Bouckaert, G. De Geest (Hrsg.): Encyclopedia of Law and Economics Volume III: The Regulation of Contracts, Cheltenham 2000, S. 296-328.
} 
Wettbewerbsintensität kann ebenso dazu führen, dass Firmen, die geringere Qualität erbringen, nicht vom Markt verschwinden, sodass die durchschnittliche Qualität sinkt. ${ }^{37}$

In den Handwerkszweigen, die 2004 dereguliert wurden, sind demnach zunächst zwei Teilmärkte entstanden: ein Meister-Markt und ein Nicht-Meister-Markt, der potentiell niedrigere Qualität zu geringeren Preisen anbietet. Annahmegemäß sinkt die Nachfrage im ersten Markt, da Kunden mit den entsprechenden Präferenzen in den zweiten Markt abwandern. Diese Kundenverlagerung kann im ersten Markt zu einem Austritt bestehender Unternehmen führen. Im Nicht-Meistermarkt entsteht eine neue (oder zuvor auf grauen Märkten bediente) Kundennachfrage, die von neu gegründeten Unternehmen bedient wird. Der Nachfrageanstieg im zweiten Markt ist größer als die Nachfragereduktion im ersten Markt, sofern die höheren Preise vor der Deregulierung die Nachfrage reduziert hatten. Dementsprechend können positive Beschäftigungseffekte erwartet werden. Die neu entstandene Nachfragekurve ist elastischer als die Nachfragekurve im Meistermarkt, da davon auszugehen ist, dass sich preissensible Kunden mit geringerer Qualitätsnachfrage auf diesem Markt bewegen.

Unter der Annahme, dass potentielle Informationsasymmetrien von den Marktakteuren überwunden werden können, entsteht ein qualitativ und preislich differenzierter Markt, wobei ggf. auftretende durchschnittliche Qualitätssenkungen vollständig durch die Präferenzen der Konsumenten bedingt sind und der Preis Informationen über die Qualität des Produkts kommuniziert. Der Meisterbrief reduziert auf diesem Markt die Suchkosten für Konsumenten hinsichtlich zu erwartender Qualität und ist somit lediglich ein möglicher Bestandteil der im Marktprozess entstehenden informationsökonomischen Mechanismen zur Vermittlung von Produkt- und Dienstleistungseigenschaften. ${ }^{38}$

In Hinblick auf den Erwerb von Qualifikationen ist anzunehmen, dass die Ausbildung direkte monetäre- sowie Opportunitätskosten bedingt. Daher ist für Anbieter niedrigerer Qualität ein Verzicht auf Teile der Ausbildung rational und entspricht den Präferenzen der Nachfrager. Es ist folglich eine Abnahme der Humankapitalbildung (im Fall des Handwerks besonders der Meisterausbildungen) zu erwarten. Die Meisterpflicht beeinflusst außerdem das Kosten-

\footnotetext{
${ }^{37}$ Eine Markteintrittsbarriere muss allerdings nicht zwingend die Existenz einer Monopolrente bedingen, sofern hinreichend Wettbewerb im regulierten Markt besteht. Für das Handwerk ist dies denkbar, da viele Handwerkerleistungen auch von nicht handwerklichen (und damit nicht zugangsbeschränkten) Handels- und Industrieunternehmen angeboten werden (können), sodass potentiell auch auf die zugangsbeschränkten Unternehmen auch vor der Deregulierung Wettbewerbsdruck ausgeübt wurde.

${ }^{38}$ Vgl. K. Fredriksen, P. Runst, K. Bizer: Masterful Meisters? Voluntary Certification and Quality in the German Crafts Sector, in: German Economic Review (i.E.).
} 
Nutzen-Kalkül der betrieblichen Entscheidung in Hinblick auf die Gesellenausbildung. Der Grund hierfür ist, dass über die Meisterausbildung nicht nur die Marktzugangsberechtigung erworben, sondern gleichzeitig eine Ausbildereignungsprüfung abgelegt wird. Durch diese Ausbildungserlaubnis erhöht sich die Wahrscheinlichkeit, dass ein Betrieb ausbildet. Denn zum Zeitpunkt der Entscheidung, ob ein meistergeführtes Handwerksunternehmen Gesellen ausbilden möchte oder nicht, spielt der zeitliche und materielle Aufwand für den früheren Erwerb der Meisterqualifikation keine Rolle mehr, es handelt sich um sunk costs. In deregulierten Handwerkszweigen hingegen verfügen Unternehmensgründer ohne Meisterausbildung i.d.R. nicht über eine Ausbildungserlaubnis und kommen möglicherweise zu dem Ergebnis, dass die Kosten des Erwerbs einer Ausbildungsberechtigung den potenziellen Nutzen übersteigen. Es kann somit vermutet werden, dass die Ausbildungsleistung von Nicht-Meister-Unternehmen geringer ist.

Es ist daher anzunehmen, dass die neuen Unternehmer eine geringere durchschnittliche Ausbildung besitzen und dadurch potentiell geringere formale unternehmerische Qualifikationen besitzen. Darüber hinaus sind die Investitionen in den Marktzugang für Betriebe ohne die Pflicht zum Meisterbrief geringer, sodass ein schneller Wechsel in andere Beschäftigungen mit geringeren Verlusten der Investition in das eigene Humankapital möglich wird, was für eine höhere Markteintritts- und -austrittsdynamik der Betriebe im deregulierten Markt spricht.

Ferner ist anzunehmen, dass die Meisterpflicht zu Ausschlusseffekten im Hinblick auf die Qualifikationserfordernisse führt, die in besonderem Maße bei Migranten zutreffen, da ihre spezifischen Kosten für die Erlangung der Qualifikation aus verschieden Gründen (z.B. Kindheit in einem nicht-europäischen Schulsystem) oftmals prohibitiv hoch sind. Es kann also angenommen werden, dass ein Wegfall der Meisterpflicht die Selbstständigenquote von Migranten erhöht. Wenn diese neuen Unternehmer informelle Netzwerke nutzen, um Angestellte zu rekrutieren, wird sich der Migrantenanteil auch unter den abhängig Beschäftigten erhöhen.

Aus Wettbewerbsperspektive sind auf Basis obiger Annahmen folgende Entwicklungen durch die Deregulierung zu erwarten: Die Einkommen (ggf. Monopolrenten) der Anbieter sinken, die Preise sinken während das Marktvolumen steigt, ebenso wie die Zahl der Marktein- und austritte. Die Gesamtbeschäftigung steigt bei höherer Beteiligung von Migranten, gleichzeitig sinkt die Zahl der Berufsbildungsabschlüsse. Die empirisch überprüfbaren Komponenten der Wettbewerbsperspektive sind damit die Reformeffekte in Hinblick auf die: (1) Einkommen 
der Anbieter (2) Preise und Marktvolumen, (3) Anzahl der Unternehmen sowie Marktein- und austritte, (4) Erwerbsbeteiligung von Migranten, (5) Beschäftigungseffekte sowie (6) Zahl der Berufsbildungsabschlüsse.

\subsection{Marktversagenshypothese}

Die theoretische Gegenposition basiert auf informationsökonomischen Argumenten und geht davon aus, dass qualifikationsbezogene Regulierung vor allem dem Konsumentenschutz dient. Die zugrundeliegende Annahme der Marktversagenshypothese besteht in einer asymmetrischen Informationsverteilung zwischen Produzenten und Konsumenten, die nicht durch marktendogene Instrumente aufgelöst werden kann. Die berufsbezogene Markteintrittsregulierung wird als eine effiziente Lösung dieses Informationsproblems angesehen. $^{39}$

Auf Handwerksmärkten existiert demnach eine asymmetrische Informationsverteilung hinsichtlich der Produkt- und Dienstleistungsqualität, da angenommen wird, dass handwerkliche Tätigkeiten in den Bereich der Erfahrungs-, oder Vertrauens-/Glaubensgüter fallen. Die Produkte werden zumeist individuell angefertigt und es gibt kaum Möglichkeiten zur Standardisierung, sodass Verbraucher Qualitätsunterschiede zwischen Produkten und Produzenten nicht oder nur schwer unterscheiden können. Hierdurch entsteht ein erheblicher Wissensunterschied zwischen Produzenten und Konsumenten. Die differenzierten Zahlungsbereitschaften für verschiedene Qualitätsniveaus resultieren dabei nicht in entsprechend informativen Preisen. Im Extremfall entsteht ein „Market for Lemons“, in dem Anbieter hoher Qualität den Markt verlassen (Adverse Selection), da der Konsument nur bereit ist, den Durchschnittspreis zu zahlen und er nicht weiß, ob er es mit einem Anbieter hoher oder niedriger Qualität zu tun hat. Die durchschnittliche Qualität von Produkten und Dienstleistungen (und die entsprechende Zahlungsbereitschaft) sinken sukzessive durch den Austritt von Anbietern hoher Qualität bis der Markt zusammenbricht. ${ }^{40}$

\footnotetext{
${ }^{39}$ Vgl. C. C. von Weizsäcker: A welfare analysis of barriers to entry, in: The bell journal of economics (1980), H. 11, S. 399-420 sowie E. Graddy: Toward a general theory of occupational regulation, in: Social Science Quarterly (1991), H. 72, S. 676-695, zitiert nach A. Haupt, N. Witte: Occupational Licensing and the Wage Structure in Germany, in: KIT Working Paper Series in Sociology (2016), H. 4.

${ }^{40}$ Vgl. hierzu grundlegend G. A. Akerlof: The Market for "Lemons". Quality Uncertainty and the Market Mechanism, in: The Quarterly Journal of Economics, 84. Jg. (1970), H. 3, S. 488-500; sowie zur Informationsökonomik des Handwerkssektors W. B. Röber: Eine informationsökonomische Analyse des Handwerks. Dissertation, Leuphana Universität Lüneburg 2009.
} 
Als Gegenstrategie kann im regulierten Markt die Meisterpflicht als eine ausbildungsbezogene Marktzugangsbeschränkung genutzt werden, da sie mit dem Erwerb von berufsspezifischem Humankapital verbunden ist. Die Anbieter im regulierten Markt sind nach Erlangung des Qualifikationsgrads befähigt, ein höheres Qualitätsniveau anzubieten, das sie ohne die Meisterausbildung potentiell nicht erreichen könnten (Humankapitalbildung). Alternativ werden hauptsächlich diejenigen Personen eine Meisterausbildung beginnen, die davon ausgehen, die Prüfung erfolgreich abschließen zu können, um so der Kundenseite ihre Qualität zu signalisieren, selbst wenn die Ausbildung an sich keine Produktivitätssteigerung auslösen würde (Signalling).

Aufgrund des höheren Humankapitalerwerbs wird davon ausgegangen, dass der zugangsbeschränkte Markt durch höhere Qualität gekennzeichnet ist und so ein sukzessiver Qualitätsverlust aufgrund asymmetrischer Informationsverteilung verhindert wird. Gleichzeitig wird angenommen, dass der durch die qualifikatorische Zugangsbegrenzung verminderte Wettbewerb im regulierten Markt nicht bewirkt, dass Handwerksunternehmen die Informationsasymmetrien zu ihrem Vorteil ausnutzen und systematisch niedrigere Qualität bei hohen Preisen erbringen. Die Meisterausbildung wird als ein Grund dafür angesehen, da sie die Herausbildung einer starken beruflichen Identität befördert, die sich u.a. durch intrinsische Qualitätsansprüche als Basis der Betriebsreputation und der Weitergabe impliziten Wissens im Rahmen der betrieblichen Ausbildung definiert. Dieses System qualifikatorischer Erfordernisse bei gleichzeitiger Reduktion des Marktdrucks durch Niedrigqualitätsanbieter kann dabei als eine spezifische deutsche institutionelle Lösung des Problems asymmetrischer Informationen interpretiert werden, die durch ein historisch gewachsenes Geflecht formeller und informeller Institutionen zwischen Marktzugang, Berufsidentität, Reputationsstreben, Qualitätsniveau und Ausbildungsneigung stabilisiert wird.

Aus Marktversagensperspektive sind damit insbesondere zwei empirisch überprüfbare Komponenten relevant, nämlich die (6) Effektivität marktendogener Informationsmechanismen sowie (7) Entwicklung des durchschnittlichen Qualitätsniveaus und der Preise. 


\section{3 Überblick}

Tabelle 1 gibt auf Basis der beiden vorgestellten Grundpositionen einen Überblick zu den theoretisch zu erwartenden Effekten der Deregulierung. Außerdem werden die bisherigen empirischen Ergebnisse kompakt aufgelistet; eine ausführliche Vorstellung der einzelnen Studien folgt in Abschnitt drei.

Tabelle 1: Übersicht über die untersuchten Studien ${ }^{41}$

\begin{tabular}{|c|c|c|c|c|}
\hline Abschnitt & Variable & Vorhersage & Ergebnis & Studien \\
\hline \multirow[t]{2}{*}{3.1} & Einkommen & negativ & $\begin{array}{l}\text { schwach } \\
\text { negativ }\end{array}$ & $\begin{array}{l}\text { Bol (2014), Bol und Weede } \\
\text { (2014), Lergetporer et al. } \\
\text { (2016), Haupt (2016), } \\
\text { Damelang et al. (2017), } \\
\text { Fredriksen (2017), Koch und } \\
\text { Nielen (2017) }\end{array}$ \\
\hline & Preise und Marktvolumen & $\begin{array}{l}\text { sinkende Preise, } \\
\text { höheres } \\
\text { Marktvolumen }\end{array}$ & $\mathrm{n} / \mathrm{a}$ & $\mathrm{n} / \mathrm{a}$ \\
\hline 3.2 & $\begin{array}{l}\text { Anzahl Unternehmen, } \\
\text { Markteintritte \& } \\
\text { Marktaustritte }\end{array}$ & positiv & positiv & $\begin{array}{l}\text { Rostam-Afschar (2014, 2015), } \\
\text { Müller (2014, 2016), Koch und } \\
\text { Nielen (2017), Zwiener (2017), } \\
\text { Runst et al. (i. E.) }\end{array}$ \\
\hline 3.3 & $\begin{array}{l}\text { Unternehmensgründungen } \\
\text { und Beschäftigung von } \\
\text { Migranten }\end{array}$ & positiv & positiv & Runst (2017) \\
\hline 3.4 & Beschäftigung & nicht eindeutig & keine Effekte & $\begin{array}{l}\text { Koch und Nielen (2017), } \\
\text { Zwiener (2017) }\end{array}$ \\
\hline 3.5 & $\begin{array}{l}\text { Anzahl der } \\
\text { Berufsbildungsabschlüsse }\end{array}$ & negativ & widersprüchlich & $\begin{array}{l}\text { Müller (2016), Koch und } \\
\text { Nielen (2017) }\end{array}$ \\
\hline \multirow[t]{2}{*}{3.6} & $\begin{array}{l}\text { Herausbildung } \\
\text { marktendogener } \\
\text { Informationsmechanismen }\end{array}$ & nicht eindeutig & schwach positiv & $\begin{array}{l}\text { Fredriksen et al. (i.E.), Röber } \\
(2009)\end{array}$ \\
\hline & Entwicklung der Qualität & Nicht eindeutig & $\mathrm{n} / \mathrm{a}$ & \\
\hline
\end{tabular}

\footnotetext{
${ }^{41}$ Die Literaturangaben der o.g. Studien sind in Kapitel drei aufgeführt.
} 


\section{3. Überblick über die empirische Literatur}

Bevor auf die einzelnen Studien eingegangen wird, ist es notwendig, zunächst auf die schwierige Datenlage zu verweisen. Die gesamte Population der Handwerksunternehmen wird zwar in den durch die Handwerkskammern geführten Verzeichnissen sowie in der Handwerkszählung erfasst. Allerdings sind diese Daten nur in aggregierter Form auf der Ebene der Handwerkszweige, nicht jedoch als Firmendatensätze verfügbar. Die aggregierte Form schränkt die Nutzungsmöglichkeiten dieser Daten auf nur wenige Fragestellungen (Zutritte und Austritte, Betriebsbestand, tätige Personen, Umsatz und Ausbildungsstand) ein. In den verfügbaren Individual- und Firmendatensätzen besteht hingegen die Problematik einer trennscharfen Abgrenzung des Handwerks. Es besteht zwar die Möglichkeit, für die Identifikation der Handwerksbeschäftigten hilfsweise auf die Klassifikation der Berufe und unterschiedliche Berufskennziffern zurückzugreifen. Da diese beruflichen Klassifizierungen allerdings nicht der offiziellen Liste der Handwerksordnung entsprechen, müssen für viele Studien Zweifel angemeldet werden, inwiefern die Untersuchungsgruppe tatsächlich aus Handwerksbeschäftigten nach der rechtlich vorgegebenen Klassifizierung besteht. ${ }^{42}$

Darüber hinaus gehen mehrere Studien davon aus, dass die Reformeffekte durch Differenzvon-Differenzen-Schätzungen (DvD) untersucht werden können, da man sowohl die deregulierte Gruppe (Treatment Gruppe) als auch die Vergleichsgruppe (Kontrollgruppe) vor und nach der Reform beobachten kann. Um kausale Zusammenhänge aufzudecken, fordert diese Methodik jedoch, dass die statistischen Parameter in zulassungsfreien und zulassungspflichtigen Handwerken - bis auf die Reformeffekte - dem gleichen Trend folgen (parallel-trends Annahme). Diese Annahme kann nicht vollständig überprüft werden. Die Wahrscheinlichkeit, dass die Annahme zutrifft, sollte folglich durch verschiedene Tests abgeschätzt werden, was jedoch in einigen Studien nicht geschieht oder nicht zu eindeutigen Ergebnissen führt. Damit ist es teilweise problematisch, Aussagen über die Robustheit der Ergebnisse zu formulieren.

\footnotetext{
${ }^{42}$ Die Forschergruppe am ifh Göttingen entwickelte mit Blick auf diese Herausforderung ein KlassifizierungsVerfahren, um Individuen im Handwerkssektor von anderen Wirtschaftsbereichen abzugrenzen, vgl. P. Runst et al.: A replication of ,Entry regulation and entrepreneurship. A natural experiment in German craftmanship ', in: Empirical Economics. Die unterschiedliche Abgrenzungsverfahren und die mit ihnen verbundenen Einschränkungen werden ausführlicher besprochen in: K. Haverkamp: Das Handwerk - Zur definitorischen und statistischen Abgrenzung eines Querschnittsbereichs, in: Zeitschrift für KMU und Entrepreneurship (i.E.).
} 


\subsection{Einkommen}

Auf Basis der bisherigen Studien lässt sich festhalten, dass die Einkommenseffekte der Reform wahrscheinlich negativ, aber gering ausfallen.

Sowohl Bol $(2014)^{43}$ als auch Bol \& Weede $(2014)^{44}$ zeigen, dass Selbstständige bzw. Beschäftigte in regulierten Berufen grundsätzlich höhere Einkommen beziehen als in nicht regulierten Berufen. Deregulierung sollte demnach zu Einkommensverlusten führen. Beide Studien sind allerdings als problematisch zu betrachten, da sie aufgrund der Nutzung von Querschnittsdaten nicht als Untersuchung der kausalen Effekte der Handwerksreform verstanden werden können.

Lergetporer et al. $(2016)^{45}$ untersuchen auf Basis zweier Datensätze die Auswirkungen der Handwerksnovelle 2004 auf das Einkommen von Selbstständigen und abhängig Beschäftigten im Handwerk. Mit den Daten der Stichprobe der Integrierten Arbeitsmarktbiografien (SIAB) zeigen die Autoren, dass im Durchschnitt über die sechs Jahre nach der Novelle der durchschnittliche Tageslohn eines abhängig Beschäftigten in B1-Handwerken insgesamt geringfügig (-0,7\%) gesunken ist. Bei Differenzierung nach Jahren zeigt sich, dass es in den ersten 4 Jahren keinen Effekt gab und erst für 2009 und 2010 ein deutlicher negativer Lohneffekt von $-3 \%$ auftrat. Bei der Nutzung von Mikrozensusdaten im gleichen Zeitraum zeigen die Ergebnisse einen negativen Einkommenseffekt von -12\% für alle Erwerbstätigen im Handwerk und von $-9 \%$ für Selbstständige im Handwerk. ${ }^{46}$ Problematisch ist hieran, dass die Autoren Haushaltseinkommen anstatt Individualeinkommen nutzen und unklar bleibt, welches Abgrenzungsverfahren für die Population der Handwerksbeschäftigten in dem Mikrozensusdatensatz verwendet wurde.

Damelang et al. $(2017)^{47}$ nutzen ebenfalls die SIAB-Daten um den Effekt der Handwerksderegulierung auf das Einkommen von Erwerbstätigen in den B1-Handwerken zu

\footnotetext{
${ }^{43}$ T. Bol: Economic returns to occupational closure in the German skilled trades, in: Social Science Research (2014), H. 46, S. 9-22.

${ }^{44}$ T. Bol, K. Weeden: Occupational Closure and Wage Inequality in Germany and the United Kingdom, in: European Sociological Review (2014), H. 19, S. 1-16.

${ }^{45}$ P. Lergetporer, J. Ruhose, L. Simon: Labor Market Effects of Entry Barriers to Self-Employment. Evidence from Deregulating the German Crafts Sector, in: Ifo Center for the Economics of Education (2016), Ifo Institute.

${ }^{46}$ Stärkere Effekte für Angestellte (im Vergleich zu Selbständigen) werden mit der divergierenden Entwicklung der Gesamtarbeitszeit erklärt, die bei den Selbstständigen größeren Anpassungen unterliegt.

47 A. Damelang, A. Haupt, M. Abraham: Economic consequences of occupational deregulation. Natural experiment in the German crafts, in: Acta Sociologica (2017), S. 1-16.
} 
untersuchen. Es zeigt sich, dass der monatliche Lohn der abhängig Beschäftigten im deregulierten Bereich bis zum Jahr 2008 nur minimal gesunken ist. ${ }^{48}$

Auf Basis von Daten des IAB-Betriebspanels und auf einem anspruchsvollen Abgrenzungsverfahren basierend, finden Koch und Nielsen $(2017)^{49}$ keinen Effekt der Reform auf die Löhne der Erwerbstätigen im Handwerk.

Fredriksen $(2017)^{50}$ nutzt Mikrozensusdaten, um die Einkommenseffekte der Novelle auf verschiedene Gruppen von selbständigen Handwerkern zu untersuchen und findet keine signifikanten Einkommenseffekte.

Haupt $(2016)^{51}$ zeigt, dass die Arbeitnehmer in den deregulierten Handwerken geringere Lohnzuwächse zu verzeichnen haben als die Arbeitnehmer in den zulassungspflichtigen Berufen. Der Effekt der Reform auf die Löhne zeigt sich vor allem in Westdeutschland und für Niedrigqualifizierte, allerdings sind die Ergebnisse nur schwach signifikant. Interessant ist hierbei die Nutzung von Daten des Sozio-oekonomischen Panels (SOEP), die - im Unterschied zum Mikrozensus - Paneldaten liefern. Da folglich die gleichen Individuen über die Zeit untersucht werden, stellt nicht-beobachtbare Heterogenität in diesem Fall kein Problem dar.

\subsection{Anzahl Unternehmen, Markteintritte \& Marktaustritte}

Deskriptive Statistiken bei Müller $(2016)^{52}$, welche auf den Daten der Handwerkskammerverzeichnisse basieren, zeigen einen schlagartigen Anstieg der Neugründungen im Handwerk nach 2004. Es wird ferner gezeigt, dass sich die Marktaustrittsrate in den betroffenen Branchen ebenfalls deutlich erhöht hat. Müller $(2014)^{53}$ untersucht die Stabilität der Unternehmensgründungen im Handwerk und zeigt, dass die Überlebensraten der neu gegründeten Unternehmen im deregulierten Bereich nach der

\footnotetext{
${ }^{48}$ Die Autoren untersuchen allerdings nicht, ob die Annahme paralleler Trends (,parallel trends assumption“) zutrifft, sodass es zweifelhaft bleibt, ob die Änderung kausal durch die Reform ausgelöst wurden.

${ }^{49}$ A. Koch, A. S. Nielen, S., Ökonomische Wirkungen der Handwerksnovelle 2004: Ergebnisse einer Kontrollgruppenanalyse, Perspektiven der Wirtschaftspolitik Jg. 18 (2017), H. 1, 72-85.

${ }^{50}$ K. Fredriksen: Do legal restrictions to accessing professions impact incomes? The German crafts case, in: ifh Working Papers No.11 (2017), ifh Göttingen.

${ }^{51}$ A. Haupt: Zugang zu Berufen und Lohnungleichheit in Deutschland, Wiesbaden 2016.

${ }^{52}$ K. Müller: Wirkungen der Handwerksreform von 2003, in: Zeitschrift für Wirtschaftsverwaltungsrecht (2016), H. 2/2016.

${ }^{53}$ K. Müller: Stabilität und Ausbildungsbereitschaft von Existenzgründern im Handwerk, in: Göttinger Handwerkswirtschaftliche Studien, H. 94, Duderstadt 2014.
} 
Reform deutlich absinken, während sie im weiterhin regulierten Bereich der A-Handwerken gleich bleiben.

Rostam-Afschar $(2014,2015)^{54}$ nutzt als erster Individualdaten des Mikrozensus, um zu prüfen, ob sich die Wahrscheinlichkeit, selbstständig $\mathrm{zu}$ werden, in den geöffneten Handwerkszweigen im Vergleich zu den nicht-deregulierten Gewerken erhöht hat. Die Ergebnisse belegen die These eines erhöhten Markteintritts; die stärksten Effekte zeigen sich für Niedrigqualifizierte. Einige Ergebnisse stehen allerdings im Widerspruch zu den theoretisch abgeleiteten Aussagen. ${ }^{55}$ So findet Rostam-Afschar, dass die Gründungszuwächse in den teilweise und vollständig deregulierten Gewerken gleich groß ausfallen. Gleichzeitig gibt es nach seinen Ergebnissen keine Hinweise darauf, dass die Austrittswahrscheinlichkeiten gestiegen sind.

Runst et al. $(2016)^{56}$ replizieren Rostam-Afschar (2014). Der zentrale Beitrag dieser Studie ist ein präziseres Abgrenzungsverfahren, um Handwerks- von nicht-Handwerksbeschäftigten zu unterscheiden. Die Befunde bestätigen zwar den von Rostam-Afschar festgestellten erhöhten Markteintritt in Folge der Reform. Es zeigt sich ein starker Reformeffekt in Form erhöhter Markteintritte in den B1-Handwerken, aber ein deutlich schwächerer Effekt in den teilweise deregulierten A-Handwerken. Im Gegensatz zu Afschar (2014) wird zusätzlich ein erhöhter Marktaustritt in den deregulierten Gewerken festgestellt.

Koch \& Nielen $(2017)^{57}$ nutzen als Datenquellen zum einen das IAB-Betriebspanel, zum anderen aggregierte Unternehmensdaten des Zentralverbandes des Deutschen Handwerks. Sie zeigen eine deutliche Steigerung der Gründungszahlen in den zulassungsfrei gestellten Handwerkszweigen in Folge der Reform.

Zwiener $(2017)^{58}$ untersucht schließlich die Auswirkungen der Reform auf die Zahl der Betriebe und Neugründungen auf Basis von drei Datensätzen: der ZDH-, der SIAB- und der

\footnotetext{
${ }^{54}$ D. Rostam-Afschar: Entry Regulation and Entrepreneurship. A Natural Experiment in German Craftsmanship, in: Empirical Economics: a journal of the Institute for Advanced Studies, Vienna, Austria, 47. Jg. (2014), H. 3, S. 1067-1101; D. Rostam-Afschar: Regulatory Effects of the Amendment to the HwO in 2004 in German Craftsmanship, in: European Commission, Research Report, Directorate General Internal Market and Services (2015).

${ }^{55}$ Vgl. L. Branstetter et al.: Do Entry Regulations Deter Entrepreneurship and Job Creation? Evidence from Recent Reforms in Portugal, in: The Economic Journal, 124. Jg. (2014), H. 577, S. 805-832.

${ }^{56}$ P. Runst et al.: A replication of ,Entry regulation and entrepreneurship. A natural experiment in German craftmanship', in: Empirical Economics (i.E.).

57 A. Koch, S. Nielen: Ökonomische Wirkungen der Handwerksnovelle 2004. Ergebnisse einer Kontrollgruppenanalyse, in: Perspektiven der Wirtschaftspolitik, 18. Jg. (2017), H. 1, S. 72-85.

${ }^{58}$ H. S. Zwiener: Essays on the German labor market, Dissertation, Humboldt-Universität zu Berlin (2017).
} 
Mikrozensusdaten. Auch hier zeigt sich eine positive Wirkung der Reform auf die Markteintritte.

\subsection{Erwerbsbeteiligung von Migranten}

Runst $(2017)^{59}$ bestätigt die aus der Theorie abgeleitete Erwartung, dass Migranten nach der Reform verstärkt eigene Handwerksbetriebe gegründet haben, wobei der Migrantenanteil in den teilweise deregulierten A-Handwerken unverändert blieb. Der Anteil von abhängig beschäftigten Migranten im Handwerk ist nach der Reform ebenfalls gestiegen, was durch die Einstellung von Beschäftigten über informelle soziale Netzwerke der Unternehmer erklärt wird.

\subsection{Beschäftigung}

Koch \& Nielen $(2017)^{60}$ untersuchen die Effekte der Deregulierung auf die Gesamtbeschäftigung, sowie die Anteile der Betriebe mit Einstellungen bzw. Entlassungen auf Basis der Daten des IAB-Betriebspanels. Sämtliche Koeffizienten zeigen sich nicht signifikant. Allerdings verweisen die Autoren auf die Schwäche der IAB-Daten, die damit zusammenhängt, dass die Stichprobe nur substanzstarke Betriebe mit sozialversicherungspflichtig Beschäftigten einschließt. Die Autoren argumentieren, dass die gesamten Beschäftigungseffekte unter Berücksichtigung von Soloselbstständigen durchaus positiv ausfallen könnten.

Zwiener (2017) ${ }^{61}$ untersucht die Auswirkungen der Reform auf die abhängige Beschäftigung im Handwerk auf Basis von zwei Datensätzen: der Mikrozensusdaten und der Stichprobe der integrierten Arbeitsmarktbiografien. Insgesamt gibt es keine statistisch gesicherten Wirkungen der Reform hinsichtlich der abhängigen Beschäftigung. Es gibt jedoch Indizien für eine schwach negative Entwicklung. Die Studie betont allerdings die Notwendigkeit einer vorsichtigen Interpretation der Ergebnisse, da ausführliche Tests zweifeln lassen, ob die für die Verwendung dieser Methode die notwendigen statistischen Annahmen als erfüllt gelten können.

\footnotetext{
${ }^{59}$ P. Runst: The Effect of Occupational Licensing Deregulation on Migrants in the German Skilled Crafts Sector, in: ifh Working Papers No. 6 (2016), ifh Göttingen.

60 A. Koch, S. Nielen: Ökonomische Wirkungen der Handwerksnovelle 2004. Ergebnisse einer Kontrollgruppenanalyse, in: Perspektiven der Wirtschaftspolitik, 18. Jg. (2017), H. 1, S. 72-85.

${ }^{61}$ H. S. Zwiener: Essays on the German labor market, Dissertation, Humboldt-Universität zu Berlin (2017).
} 


\subsection{Ausbildung}

Müller $(2016)^{62}$ zeigt deskriptiv, dass sich in den deregulierten Zweigen der Anteil der Neugründer mit Meisterabschluss von rund 75\% vor 2004 (wobei die restlichen 25\% Ausnahmegenehmigungen zur Betriebsgründung besaßen) auf rund 20\% nach 2004 reduziert; der Anteil der Neugründer mit Gesellenabschluss beträgt in den Jahren nach der Reform noch rund $70 \%$. Er schließt daher auf negative Effekte der Reform auf das durchschnittliche Qualifikationsniveau der Betriebsinhaber im Handwerk.

Koch \& Nielen $(2017)^{63}$ bestätigen den erwarteten negativen Reformeffekt auf die Anzahl der Meisterprüfungen. Die Autoren zeigen zugleich, dass es in den ersten Jahren nach der Reform keine signifikanten Effekte der Reform auf das Ausbildungsgeschehen gab. Erst ab 2009 ist ein negativer Reformeffekt auf die Zahl der Ausbildungsplätze und die Zahl der Auszubildenden erkennbar, welcher laut den Autoren aufgrund der zeitlichen Entfernung nicht zwangsläufig auf die Reform zurückgeführt werden kann. Es werden ebenfalls keine signifikanten Wirkungen auf die Zahl der Gesellenabschlussprüfungen gefunden. Die verspätete Wirkung lässt sich allerdings damit begründen, dass aufgrund einer zeitlich befristeten Ausnahmeregelung auch nicht-Meistergeführte Betriebe in B1-Handwerken bis 2009 ausbilden durften und der negative Reformeffekt daher erst ab 2009 zu erwarten wäre. ${ }^{64}$ Auf Basis von IAB-Daten stellen die Autoren zunächst sogar positive Wirkungen der Handwerksnovelle auf das Ausbildungsverhalten der Betriebe in den deregulierten B1Handwerken fest ${ }^{65}$, welche sich aber im Folgenden als nicht robust herausstellen. Insgesamt bleibt festzuhalten, dass die Effekte der Reform auf die Zahl der Meisterprüfungen negativ und die Effekte auf das Ausbildungsgeschehen uneindeutig ausfallen.

\footnotetext{
${ }^{62}$ K. Müller: Handwerksrechtsnovelle von 2003. Was waren die Ergebnisse?, in: Gewerbearchiv, 62. Jg. (2016), H. 2, S. 54-59.

63 A. Koch, S. Nielen: Ökonomische Wirkungen der Handwerksnovelle 2004. Ergebnisse einer Kontrollgruppenanalyse, in: Perspektiven der Wirtschaftspolitik, 18. Jg. (2017), H. 1, S. $72-85$.

${ }^{64}$ Die allgemeine Aussetzung der Ausbilder-Eignungsverordnung (AEVO) der Jahre 2004 bis 2009 galt nur für die B1-Handwerke, nicht aber für die A-Handwerke. Für Gesellen der B1-Handwerke war es im Zeitraum 20042009 daher vergleichsweise günstig auszubilden, wohingegen Gesellen aus dem A-Handwerk weiterhin die Ausbildereignungsprüfung ablegen mussten. Der negative Reformeffekt konnte folglich erst ab 2009 voll zum Tragen kommen (vgl. J. Thomä: Betriebliche Ausbildungsbeteiligung - eine veränderte Anreizkonstellation durch die Handwerksnovelle 2004?, in: ifh Working Papers No. 9 (2017), ifh Göttingen).

${ }^{65}$ Ein zusätzlicher Vergleich mit Nicht-Handwerksunternehmen zeigt allerdings, dass dieser relative Effekt nicht auf einen Anstieg der Ausbildungsleistung der B1-Handwerke, sondern auf einen Rückgang der Ausbildungsaktivitäten im A-Handwerk zurückzuführen ist.
} 


\subsection{Effektivität marktendogener Informationsmechanismen}

Röber (2009) ${ }^{66}$ untersucht, ob bei der Interaktion mit verschiedenen Gewerken beim privaten Hausbau marktendogene Instrumente genutzt werden, um Informationsasymmetrien abzubauen. Sie findet, dass insbesondere Reputation und persönliche Empfehlungen bzw. Bauunternehmer für bei der Betriebsauswahl entscheidend sind. Sie argumentiert, dass der Meisterbrief allein hingegen keine umfassende Lösung bietet, da auch in weiterhin regulierten Märkten durch Verbraucher Informationsasymmetrien wahrgenommen werden.

Fredriksen et al. (i.E.) nutzen Kundenbewertungen auf der Online-Plattform MyHammer.de, um die Qualität der Handwerksleistungen zu messen. Ihre Befunde unterstützen die Annahme, dass Meisterbetriebe eine höhere Leistungsqualität anbieten, da Meisterbetriebe bessere Kundenbewertungen erzielen und länger auf der Plattform verbleiben. Die Autoren argumentieren, dass die Unterscheidung zwischen Meister- und Nicht-Meisterunternehmen den Kunden dabei hilft, eine für sie passende Preis-Qualitäts-Kombination zu finden. Diese Verminderung der informatorischen (Such-) Kosten für den Kunden wirkt dadurch einem Marktversagen auf Grund von Informationsasymmetrien entgegen.

\section{Fazit und Forschungsausblick}

Knapp fünfzehn Jahre nach der Reform der Handwerksordnung ist es möglich, eine erste Bilanz über die Reformeffekte zu ziehen.

Auffällig ist, dass der überwiegende Teil der Studien die Effekte der Deregulierung aus der Wettbewerbsperspektive beleuchtet, wobei ein Teil der wirtschaftspolitisch relevanten theoretischen Annahmen empirisch überprüft wurde. Hierbei zeigt sich, dass die Beseitigung von Marktzutrittsbeschränkungen eine Gründungswelle in dem vollständig deregulierten Teil des Handwerks auslöste. Die Abschaffung der Meisterpflicht für die neuen Gründer begünstigte dabei den Markteintritt von niedriger qualifizierten Personen und Migranten. Die verstärkte Wettbewerbsintensität in Verbindung mit der niedrigeren Humankapitalausstattung der neuen Gründer fällt mit einer Erhöhung der Marktaustrittsraten zusammen. Wenngleich es Indizien für sehr leichte negative Effekte auf die Zahl der abhängig Beschäftigten vorliegen, sind diese Ergebnisse nicht statistisch gesichert. Die Ergebnisse in Bezug auf das Ausbildungsgeschehen fallen ebenfalls uneindeutig aus. Unstrittig ist hingegen der negative

\footnotetext{
${ }^{66}$ W. B. Röber: Eine informationsökonomische Analyse des Handwerks. Dissertation, Leuphana Universität Lüneburg 2009.
} 
Reformeffekt auf die Zahl der bestandenen Meisterprüfungen. Schließlich zeigen sich in den meisten Studien negative Einkommenseffekte der Reform, die allerdings oft nur schwach signifikant und in absoluten Werten eher gering ausfallen.

Im Gegensatz zu den wettbewerbsökonomisch geprägten Fragestellungen bestehen im Bereich der Marktversagensperspektive grundlegende Forschungslücken. Die zwei bestehenden Studien zeigen in begrenztem Rahmen, dass marktendogene Informationsmechanismen bestehen, die geeignet sind, Informationsasymmetrien abzubauen. Es ist allerdings bislang offen, ob die Abschaffung qualifikationsbezogener Marktzutrittsbarrieren zu einer Senkung der durchschnittlichen Qualität geführt hat, ob diese ggf. mit den Konsumentenpräferenzen übereinstimmt oder Folge eines Problems asymmetrischer Information ist. Ferner fehlt eine Analyse der Problematik externer Effekte im Falle absinkender Qualität der handwerklichen Dienstleistungen, wie etwa Gesundheitsschädigungen, negative Umwelteffekte durch Verwendung günstigerer Materialien oder im Aggregat erhöhte Reparaturkosten.

Abschließend kann deswegen festgehalten werden, dass die wirtschaftspolitische Debatte zur Deregulierung der Handwerksordnung von 2004 auf einem ersten soliden wissenschaftlichen Fundament geführt werden kann. Es besteht jedoch weiterhin in zentralen Bereichen Forschungsbedarf, um die Folgen der Deregulierung insgesamt beurteilen zu können und empirisch fundierte Empfehlungen zur Weiterentwicklung der Handwerksordnung zu geben. 